University of Nebraska - Lincoln

DigitalCommons@University of Nebraska - Lincoln

$10-27-2017$

\title{
The geochemistry of loess: Asian and North American deposits compared
}

Daniel R. Muhs

Follow this and additional works at: https://digitalcommons.unl.edu/usgsstaffpub

Part of the Geology Commons, Oceanography and Atmospheric Sciences and Meteorology Commons, Other Earth Sciences Commons, and the Other Environmental Sciences Commons

This Article is brought to you for free and open access by the US Geological Survey at DigitalCommons@University of Nebraska - Lincoln. It has been accepted for inclusion in USGS Staff -- Published Research by an authorized administrator of DigitalCommons@University of Nebraska - Lincoln. 
Full length article

\title{
The geochemistry of loess: Asian and North American deposits compared
}

\author{
Daniel R. Muhs
}

U.S. Geological Survey, MS 980, Box 25046, Federal Center, Denver, CO 80225, USA

\section{A R T I C L E I N F O}

\section{Keywords:}

Asia

North America

Loess

Geochemistry

Major elements

Trace elements

Provenance

Paleosols

Chemical weathering

Paleoclimates

\begin{abstract}
A B S T R A C T
Loess is widely distributed over Asia and North America and constitutes one of the most important surficial deposits that serve as terrestrial records of the Quaternary. The oldest Pleistocene loess in China is likely $\sim 2.6 \mathrm{Ma}$, thus spanning much or all of the Pleistocene. In North America, most loess is no older than the penultimate glacial period, with the exception of Alaska, where the record may go back to $\sim 3.0 \mathrm{Ma}$. On both continents, loess deposits date primarily to glacial periods, and interglacial or interstadial periods are represented by paleosols. Both glacial and non-glacial sources of silts that comprise the bulk of loess deposits are found on both continents. Although loess has been considered to be representative of the average upper continental crust, there are regionally distinctive compositions of loess in both Asia and North America. Loess deposits in Asia from Yakutia, Tajikistan, and China have compositionally distinct major element compositions, due to varying abundances of silicate minerals, carbonate minerals, and clay minerals. In North America, loess in the Mississippi River valley, the Great Plains, and Alaska are also distinguishable with regard to major element composition that reflects highly diverse source sediments. Trace element geochemistry (Sc-Th-Zr and the rare earth elements) also shows regional diversity of loess bodies, in both Asia and North America. On both continents, most loess bodies show significant contributions from later-cycle, altered sedimentary rocks, as opposed to direct derivation from igneous rocks. Further, some loess bodies have detectable contributions from mafic igneous rocks as well as major contributions from average, upper-crustal, felsic rocks. Intercalated paleosols in loess sections show geochemical compositions that differ significantly from the underlying loess parent materials. Ratios of soluble-to-insoluble elements show depletions in paleosols due to chemical weathering losses of calcite, dolomite, plagioclase, mica, apatite, and smectite. In Asia and North America, the last interglacial paleosol is more weathered than equivalent modern soils, which could be due either to a climate that was warmer and more humid, a longer period of pedogenesis, or both. In Asia, early Pleistocene loess and paleosols are both more weathered than those from the middle and late Pleistocene, forming prior to a mid-Pleistocene aridification of Asia from uplift of the Tibetan Plateau. Understanding the geochemistry of loess and paleosols can tell us much about past atmospheric circulation, past temperature and moisture regimes, and even tectonic processes.
\end{abstract}

\section{Introduction}

Loess is aeolian sediment that is one of the most important surficial deposits on the surface of the Earth. As used in this paper, loess can be defined as silt-dominated sediment that has been entrained, transported, and deposited by the wind and is recognizable in the field as a distinct sedimentary body. It occupies an intermediate position in a continuum of aeolian sediments, with an average particle size that is smaller than windblown sand $(2-0.05 \mathrm{~mm})$, but coarser than aerosolic dust (typically $<10 \mu \mathrm{m}$ ). Commonly, loess contains $60-90 \%$ silt-sized (50-2 $\mu \mathrm{m}$ diameter) particles, supplemented with small percentages of sand $(>50 \mu \mathrm{m})$ and clay $(<2 \mu \mathrm{m})$.

Through a century and a half of research, loess has come to be regarded as one of the most important archives of Quaternary climate change, particularly on the continent of Asia. Combined with intercalated paleosols (buried soils), loess provides one of the most complete terrestrial records of interglacial-glacial cycles. Loess is also distinctive in that it provides a direct record of atmospheric circulation. Thus, given favorable circumstances, loess can be used to reconstruct synoptic-scale paleoclimatology over millennial timescales, a significant attribute for Quaternary sediments. Further, unlike many Quaternary deposits, loess can be dated directly using methods, such as luminescence geochronology, that require only the sediment itself. Thus, the combination of loess deposits and intercalated paleosols provides a highly valued source of Quaternary paleoclimate information. In some regions, such as China, the record is long enough that inferences about Tertiary paleoclimate can even be made.

Loess can be recognized in the field as a distinctive sedimentary body, although its thickness is highly variable, from a few centimeters to several hundred meters in thickness. Indeed, variability of loess

E-mail address: dmuhs@usgs.gov. 
thickness is one of its advantages as a paleoclimate indicator, as paleowind directions can often be inferred from loess thickness trends (see examples in Muhs, 2013a, 2013b). Loess deposits are commonly draped over preexisting landforms as a mantle, with thickest accumulations in protected, low-lying areas or on broad, flat, stable upland divides. Thinnest accumulations of loess typically occur on narrow, rounded hillcrests. Loess is found as the uppermost surficial sediment over large areas of Asia, Europe, North America, South America, and New Zealand and covers smaller areas of Australia and Africa.

In this review, the geochemistry of loess is examined, with a focus on Asian loess deposits compared to those of North America. Interestingly, during a major part of the Quaternary, during times of glacially lowered sea levels, Asia and North America were connected as a contiguous landmass. Asian scientists, and particularly Chinese geologists, have been pioneers in studies of the geochemistry of loess. Early recognition of the importance of geochemistry to loess interpretations in China was made by Wen Qizhong, Diao Guiyi, Sun Fuqing, and Yu Suhua, who characterized the major and trace element geochemistry of these deposits in Liu's (1988) comprehensive volume on the loess of China. Subsequent loess researchers in Asia have followed this tradition of using geochemistry in interpretations of loess origins and paleoclimatic significance. North American loess researchers have been slower to utilize geochemical tools in their studies, but sufficient data now exist to make some useful comparisons with results derived from studies in Asia.

Two broad themes will be addressed in this review. The first is that geochemistry can be a powerful tool in understanding loess origins. The igneous and sedimentary petrology communities have used both major element geochemistry and trace element geochemistry (including the rare earth elements, REEs) in trying to understand the genesis and compositional evolution of rocks. Applications of geochemical methods to loess research naturally follow the approaches that have been taken by sedimentary petrologists, but such efforts would not be particularly useful were it not for the years of careful geochemical studies of igneous rocks by the petrology community. An attempt is made here to illustrate how some relatively simple geochemical analyses can yield much potentially useful information about how loess forms. Understanding how loess is derived (its provenance) and spatial trends in its geochemical properties reveal much about paleoclimate during times of dust entrainment and transport.

The second theme that is addressed is the stratigraphic complement to the first: the origin and paleoclimatic significance of buried soils (paleosols) that represent stable land surfaces when pedogenesis was dominant between times of loess accumulation. Geochemistry of paleosols, particularly when combined with mineralogical analyses, can give important clues about the duration of pedogenesis, the prevailing climate at the time of soil formation, and sometimes even the type of vegetation that occurred during such times.

\section{Geography and geologic setting of loess deposits}

\subsection{Geography of loess in Asia}

Loess is widespread over much of Asia, particularly in Russia, China, and a number of countries in Central Asia (Fig. 1). In the Asian portion of Russia, loess is extensive in central Siberia and its depositional history has been reviewed by Chlachula (2003). Farther to the northeast, loess is also found along the Lena River in Yakutia (Péwé and Journaux, 1983). Based on mapping by Velichko et al. (1984), loess is also likely extensive along the Arctic Ocean coast of Siberia, but further studies are needed in this remote region to understand its true distribution. Loess in Central Asia is found primarily in five countries: Tajikistan, Kyrgyzstan, Turkmenistan, Uzbekistan and Kazakhstan. The loess in Tajikistan is the most studied and best understood, primarily from work by the late A.E. Dodonov and his colleagues (see review by Dodonov, 2007). Smaller areas of loess occur in Iran, Afghanistan, Pakistan and northern India (see Ahmad and Chandra (2013) for an example of the latter), but their spatial extent is known only approximately.

Without question, the most accurately mapped and best-studied loess deposits are in China, due to the pioneering efforts of T.S. Liu. Loess is found in several parts of China (Fig. 2). The largest contiguous area, and that which has received the most study, is the dissected Loess Plateau in the central part of the country, between approximately $95^{\circ} \mathrm{E}$ and $110^{\circ} \mathrm{E}$ longitude and centering on $\sim 38^{\circ} \mathrm{N}$ latitude (Figs. 2-4). In the

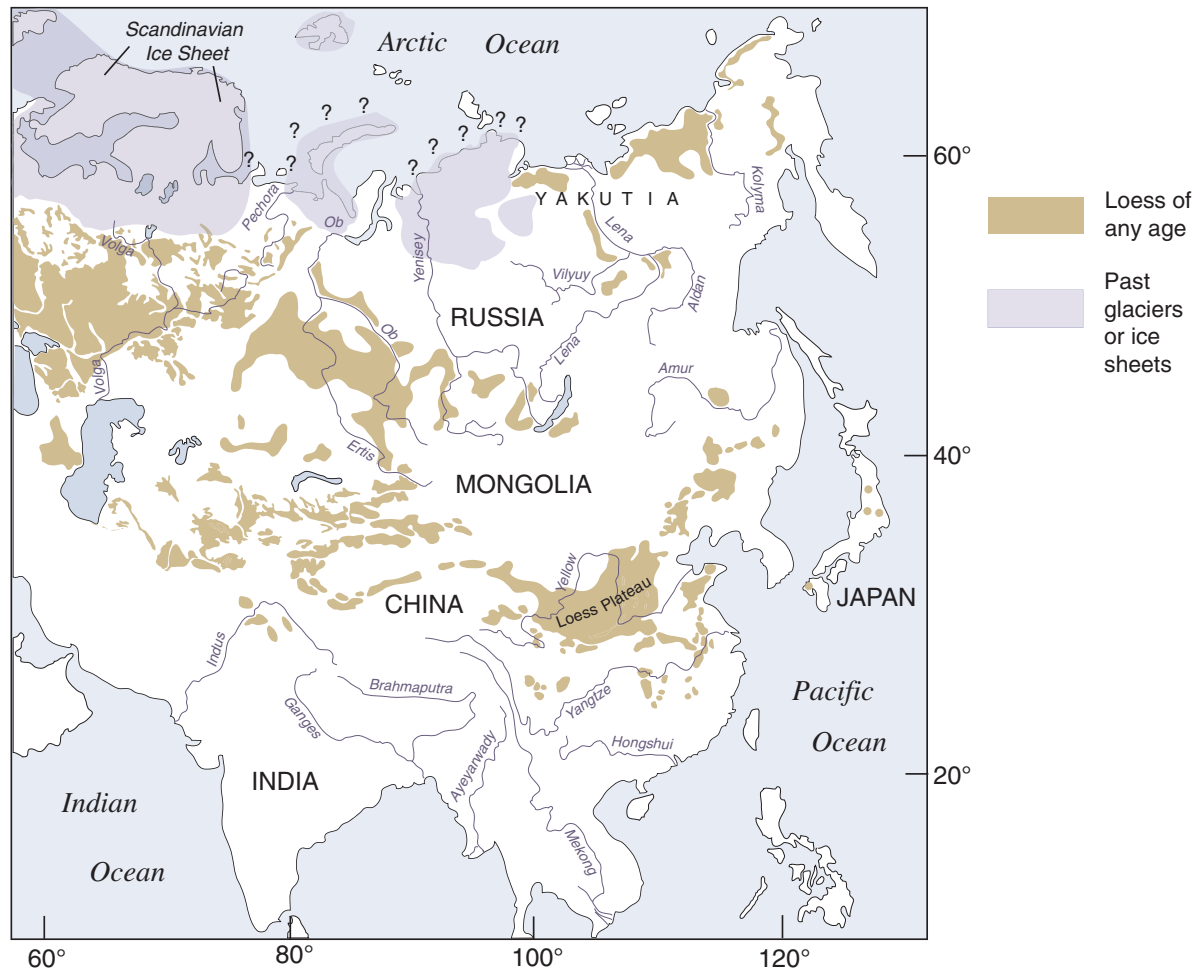

Fig. 1. Distribution of loess in Asia, compiled from Velichko et al. (1984, 2006), Liu (1988), Rozycki (1991), Dodonov (2007), and Frechen et al. (2009). Note: loess is also reported for Japan (Watanuki et al., 2005; Matsu'ura et al., 2011), but distribution maps are not shown in those reports.

Loess of

any age

glaciers

or ice

heets 


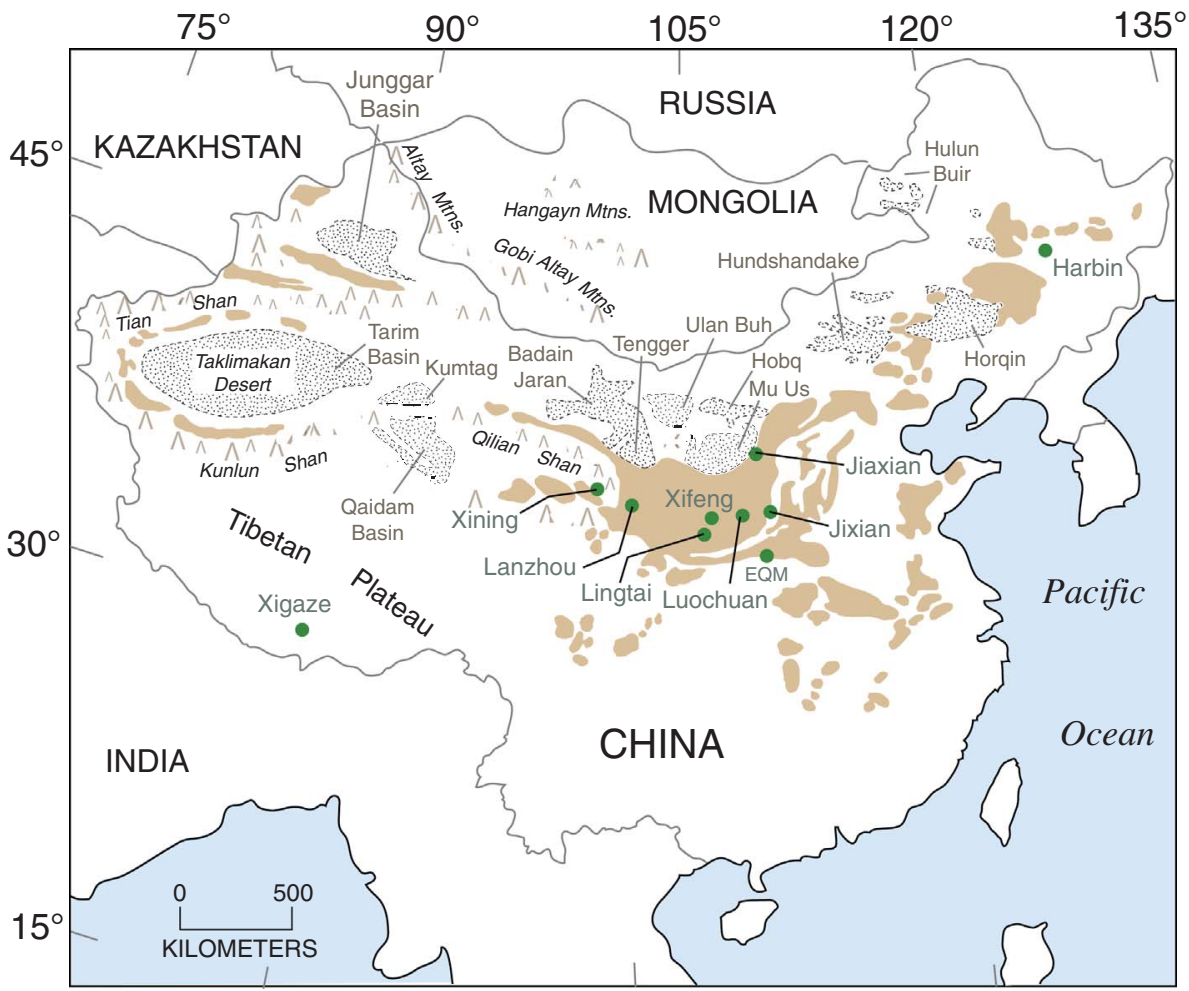

Fig. 2. Distribution of loess (brown shaded areas), sandy deserts in basins (stippled areas), mountain ranges, and localities referred to in the text in China. Loess distribution from Liu (1988) and Sun and Muhs (2007).

northwestern part of the Loess Plateau, near Lanzhou, loess deposition has been ongoing for more than 2 million years (Fig. 3). Indeed, the accumulation of loess in the Lanzhou area may be the thickest occurrence of this deposit on Earth. Smaller but still significant areas of loess are found to the south of the Loess Plateau, near the eastern part of the Qin Ling Mountains, northeast of the Loess Plateau (near Harbin), and to the south of the Tengger (a shamo, or sandy desert) (Figs. 2 and 4). Loess is also found around the rim of the Taklimakan Desert in the Tarim Basin of western China (Sun, 2002a) and in extreme northwestern China to the north of the Tarim Basin, between Mongolia and Kazakhstan (Fig. 2). Smaller occurrences of loess are found in southeastern China.

\subsection{Geologic setting of loess in Asia and rock sources for loess}

The ultimate origin of loess in China is in part linked to the plate tectonic history of Asia. This history produced the high topography that was capable of generating sediment (dust sources) and also blocked moisture sources in interior Asia, thus producing an arid environment that was favorable for the entrainment of dust. Northward migration of the Indian-subcontinent plate brought about collision with the Eurasian plate in the Eocene-Miocene (see review in Sun and Liu, 2000). This in turn resulted in crustal shortening with uplift of the Himalaya, the highest continental mountains on Earth. Creation of this dramatic topography has allowed, at least in part, the development of rain-shadowed, arid basins to the north, including the Tarim and Qaidam Basins, as well as other sandy desert basins (Fig. 2). In addition to uplift of the Himalaya, initial uplift to form the Tibetan Plateau is also thought to have begun at the time of the Indian-Eurasian plate collision. Evidence suggests, however, that uplift of the Tibetan Plateau has continued into the Pleistocene (Sun and Liu, 2000).

The raw material for loess is ultimately related to the extremely complex geologic history of Asia. A review of the geology of all of China's mountain ranges is far beyond the scope of this paper. Nevertheless, a short summary of the rock types in some selected mountainous terrains is presented here in order to show the wide variety of lithologies that could potentially contribute sediment to loess deposits in China.

Northern China and Mongolia, including the Tian Shan and the Altay Mountains, are part of the Central Asian Orogenic Belt (CAOB). This tectonic belt is bordered by two Precambrian cratons, the Siberian craton to the north and the North China-Tarim craton to the south (Jahn, 2004). As summarized by Jahn (2004), the CAOB hosts Precambrian cratonic blocks, old island arcs, parts of oceanic islands and seamounts, accretionary complexes, ophiolites, and rocks from passive continental margins. Thus, rocks in mountains of this tectonic belt span a surprising range of lithologies. However, Jahn (2004) points out that one of the distinguishing characteristics of the CAOB is the significant number of granitic intrusions. Cambrian to Cretaceous age felsic intrusive rocks in the CAOB (Wang et al., 2017) are situated around the rims of the Tarim and Junggar Basins (Fig. 2) and provide much of the sediment that is ultimately delivered to these structural and topographic depressions.

South of the Tarim Basin, the western Kunlun Shan (Fig. 5) is a part of the Western Kunlun orogenic belt (WKO) and is bounded by the Tarim block to the north and the Tibetan Plateau to the south (Hu et al., 2017). The WKO consists of four sutured terranes with a wide variety of rock types. The northern two terranes, which deliver sediment to the Tarim Basin, include metamorphic rocks (gneisses and schists) intruded by granites, but clastic sedimentary rocks, carbonates, and volcanic rocks also occur locally (Wang, 2004; Hu et al., 2017). The eastern Kunlun Shan is also north of the Tibetan Plateau and is bordered on the north by the Qaidam Basin (Fig. 2). These mountains are a part of the East Kunlun Orogenic Belt (EKOB), which also hosts extensive granitic plutons (Zhou et al., 2016). This belt has also been subdivided into different units, separated by suture zones. The northern unit is dominated by granitic rocks, but also has gneisses, amphibolites, sandstones, conglomerates, volcanic rocks, and limestones. The central unit has Precambrian basement rocks and younger granites, whereas the southern unit is dominated by Precambrian rocks, volcaniclastic rocks, clastic sedimentary rocks, and carbonate rocks (Zhou et al., 2016).

The northern portion of the northwest-southeast-trending mountains of the Qilian Shan are found to the east of the Kunlun Shan. Drainages going north from this range deliver sediments to the Badain 
(a) Luochuan

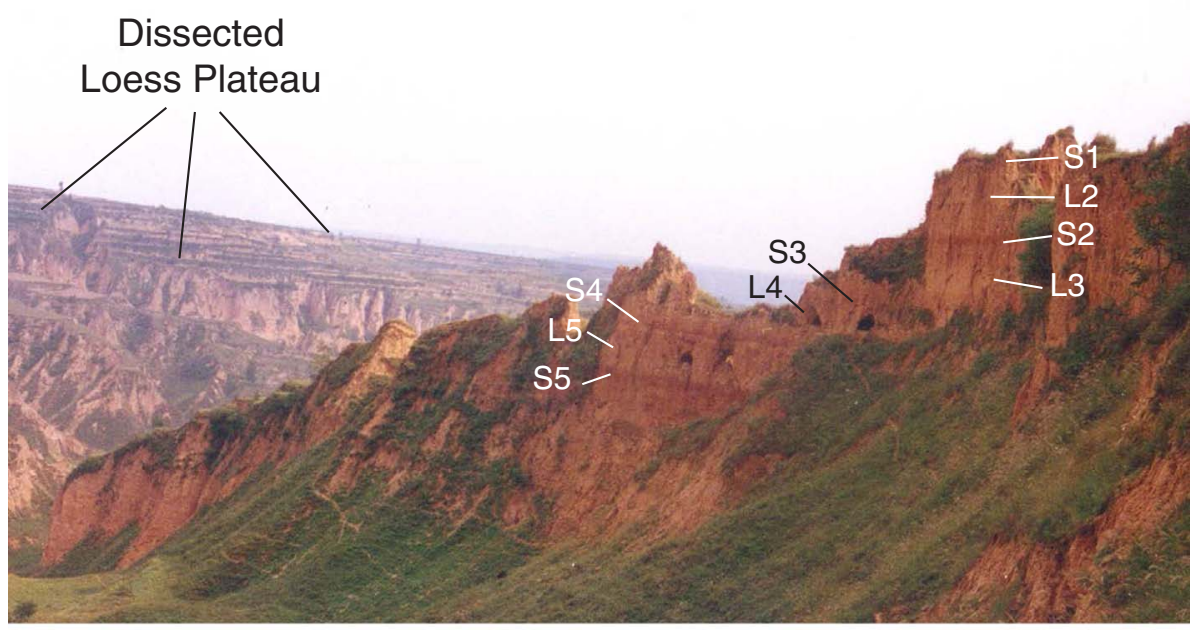

(b) Lanzhou

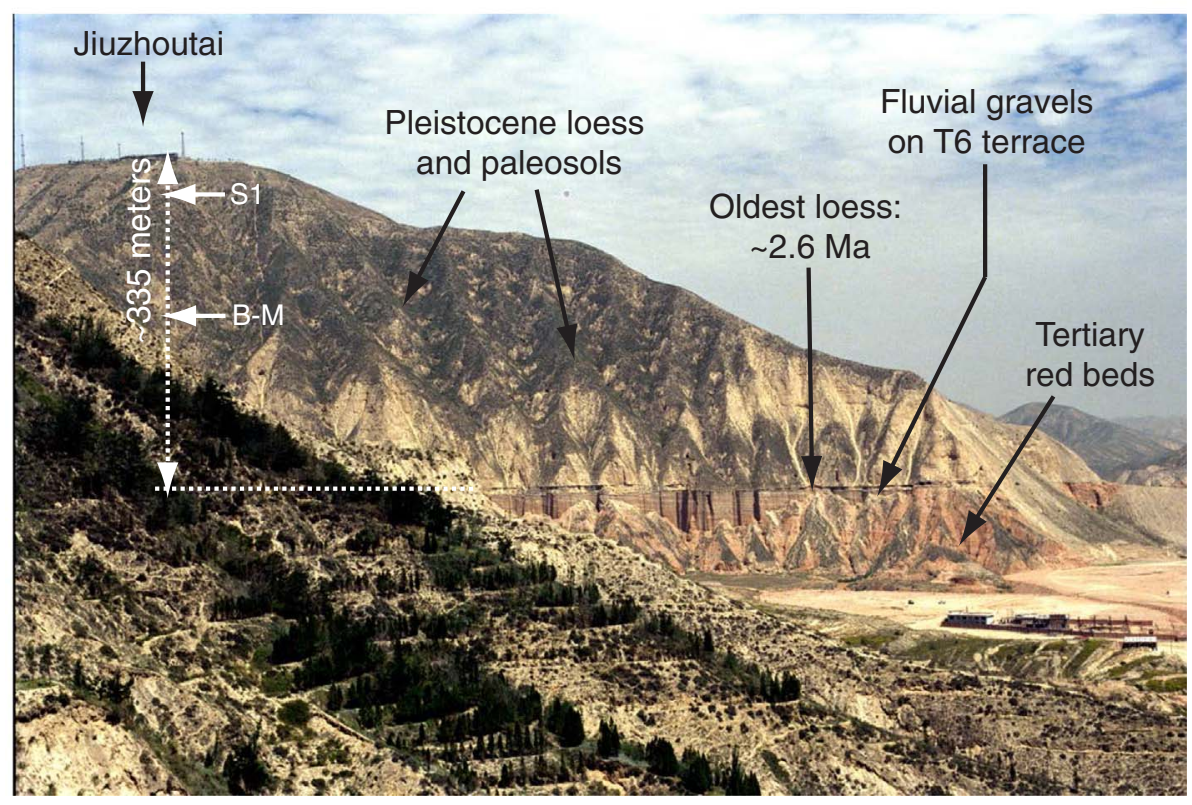

Fig. 3. (a) Exposure of a part of the classic Luochuan loesspaleosol section on the dissected Chinese Loess Plateau, showing paleosols (reddish bands, with " $\mathrm{S}$ " prefixes) alternating with loess deposits (brownish bands, with "L" prefixes). Photograph courtesy of Dr. Jimin Sun, Chinese Academy of Sciences. (b) One of the thickest loess sections in the world, exposed at Jiuzhoutai, near Lanzhou, China, looking east (see descriptions in Burbank and Li, 1985; Rolfe et al., 1989, and Chen and Li, 1991). Note that the positions of the $\sim 120 \mathrm{ka}$, last-interglacial paleosol (S1) and the $\sim 780$ ka Brunhes-Matuyama Polarity Chronozones (B-M) boundary are given only approximately in the figure. Age of the oldest loess at $\sim 2.6 \mathrm{Ma}$ is from Ding et al. (1998, 2005). Photograph courtesy of Joseph Rosenbaum, U.S. Geological Survey.
Jaran desert (Fig. 2). Rocks in the northern part of this mountain range consist of a core of granite and diorite (Fang et al., 2013). Along the northern margin of this crystalline core, there are intermediate volcanic and pyroclastic rocks, chert, phyllite, slate, sandstones, conglomerates, shale, mudstone, coal, and limestone (Fang et al., 2013). Still farther southeast, and to the south of the Chinese Loess Plateau, there is an east-west-trending range called the Qin Ling Mountains (Fig. 4). Rocks in these mountains are dominated by granites, but diorites, gabbros, metamorphic rocks, ultramafic rocks, and ophiolites are also found (Heberer et al., 2014; see their Fig. 2).

\section{3. "Glacial" loess vs. "desert" loess}

There has been much discussion about the specific origins of loess in China, particularly centering on the issue of "glacial loess" vs. "desert loess," a debate that dates back to at least the mid-20th century (Bryan, 1945; Thorp, 1945). It is generally agreed, particularly on the basis of observations of modern dust storms, that the desert basins of China and Mongolia are the immediate sources of loess in China (Liu, 1988; Liu et al., 1994; Derbyshire et al., 1998; Porter, 2001; Sun et al., 2001).
Indeed, dust storms are easily observed today on satellite imagery, emanating from the arid basins of northern and northwestern China, with movement toward the Loess Plateau (Fig. 4). The debate that continues to this day is whether the deserts are the ultimate source of silt-sized particles found in Chinese loess. This brings forth a question about whether the silt-sized sediments in the desert basins owe their origin to processes operating within the basins themselves or whether they were formed by glacial grinding in nearby mountain ranges.

Smalley and Vita-Finzi (1968) and Smalley and Krinsley (1978) propose that much of the silt in Chinese loess was produced by glacial grinding in mountain ranges, such as the Tian Shan and Kunlun Shan, rimming the desert basins (Figs. 2 and 5). Derbyshire (1983) challenged this interpretation by suggesting that glaciation in the mountains of northern and western China was of limited extent and that tills derived from glaciers in these mountains are not particularly silt-rich (although no data on silt content are reported). In Derbyshire's (1983) view, much of the silt in Chinese loess is produced by salt weathering and frost shattering, either in the desert basins themselves or in the nearby mountains. In a later paper, Smalley (1995) modified his assertion that glacial grinding was the dominant process of silt particle production for 
$105^{\circ} \mathrm{E}$

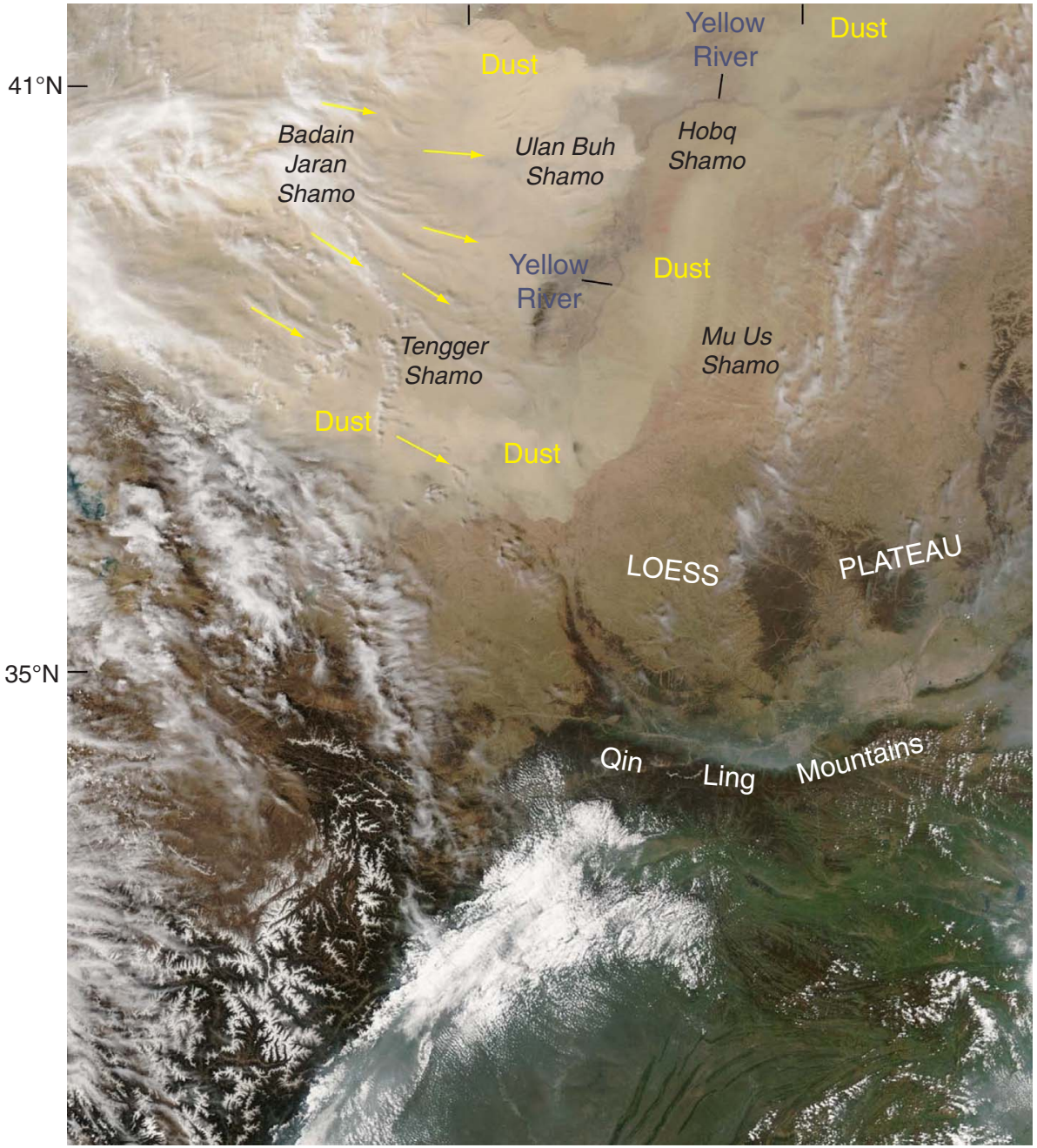

$67^{\circ} \mathrm{E}$

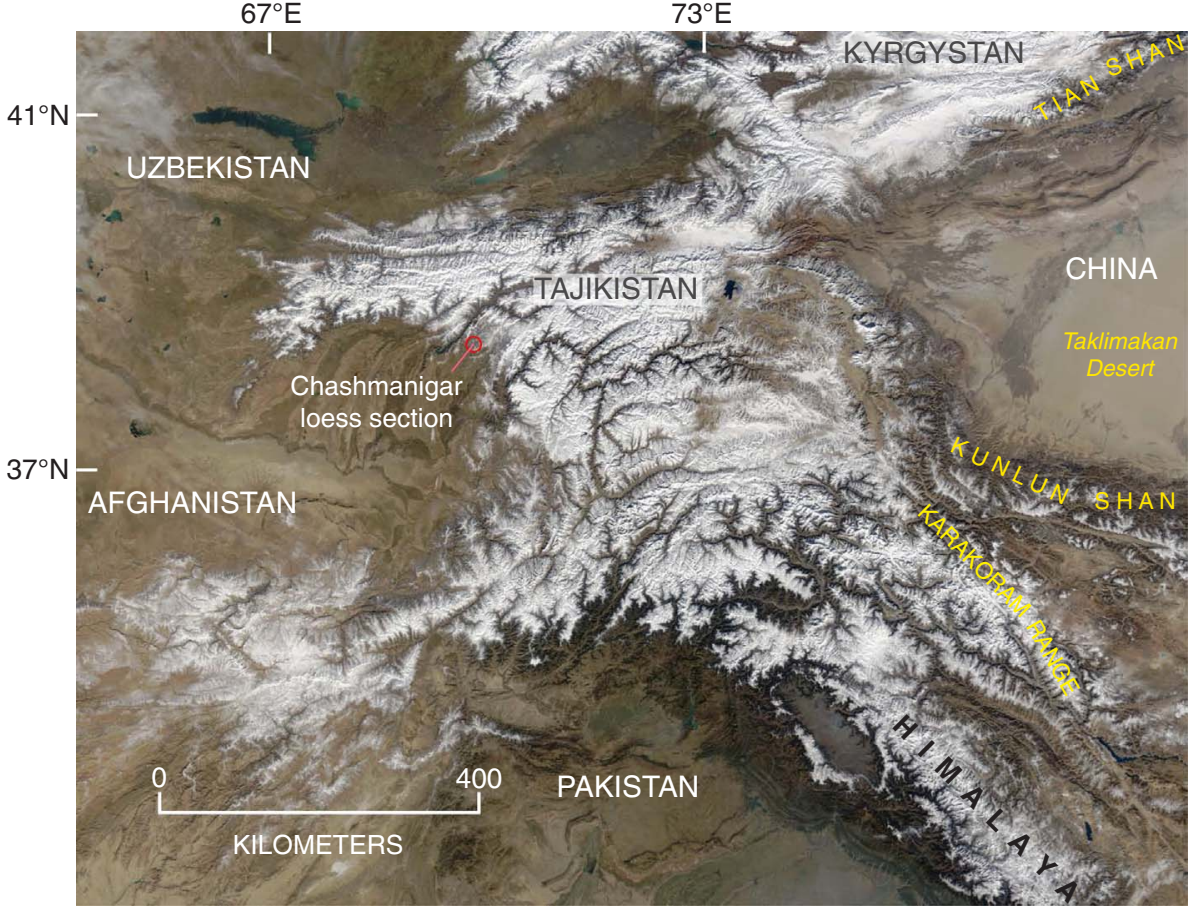

Fig. 4. Moderate Resolution Imaging Spectroradiometer (MODIS) image taken from the NASA Aqua satellite showing dust originating from the Badain Jaran Shamo, Tengger Shamo, and Ulan Buh Shamo (sandy deserts) and heading southeast towards the Chinese Loess Plateau. Image acquired on 10 April 2006, and used here courtesy of the MODIS Rapid Response Team at NASA GSFC.
Fig. 5. True-color MODIS image taken from the NASA Terra satellite showing the rugged terrain of westernmost China, Tajikistan and adjacent countries. The glaciated Tian Shan and Kunlun Shan, shown in the eastern part of the image, supply sediment to the Tarim Basin (Taklimakan Desert) which is in turn entrained by wind and accumulates as loess around the edges of the basin. Also shown is the location of the Chashmanigar loess section in Tajikistan, discussed later in the paper. Image was acquired on 28 November 2003 and is courtesy of Jeff Schmaltz, MODIS Land Rapid Response Team at NASA GSFC. 
the origin of Chinese and Central Asian loess. Instead, Smalley (1995) emphasized a suite of processes (although including glacial grinding) that are all related to high-altitude glacial or periglacial activity. $\mathrm{He}$ coined the term "mountain loess" to refer to silt particle production by the collective action of a number of geomorphic processes found at high altitudes. Wright (2001a) reiterated Derbyshire's (1983) arguments against a glacial origin for Chinese loess and agreed that salt weathering and frost shattering in the desert basins are important processes of siltparticle formation. Furthermore, she suggested that chemical weathering, fluvial comminution, and aeolian abrasion have all been important processes in Chinese silt particle formation.

It is important to point out that glaciers exist today in many of China's mountain ranges, including the Tian Shan, the Kunlun Shan, Qilian Shan, and the Borohoro Shan, as well as over many parts of the Tibetan Plateau and some parts of the Altay Mountains of nearby Mongolia (Shi, 1980; see also Figure 5 of Péwé et al. (1995), which is derived from this source). Small glaciers are even found in the Bayan Har Mountains (Zhou et al., 2004). Thus, the potential certainly exists for silt particle production by glacial grinding in China's mountains at present. Further, there is abundant geomorphic evidence that glaciers in China's mountains were more extensive in past glacial periods (Zhou et al., 2004). If this is the case, then it is certainly possible that much silt production has been the result of glacial grinding. Nevertheless, it is also true that desert processes of silt production, as outlined by Derbyshire (1983), have been successfully simulated in laboratory settings (Wright, 2001b). Moreover, it is conceivable that both glacial and non-glacial processes have contributed to silt particle production in China and Central Asia, as these groups of processes are not mutually exclusive.

\subsection{Geography and geologic setting of loess in North America}

In broadest terms, loess in North America can be found in five regions (Fig. 6). From east to west, these sediment bodies are: (1) loess of the greater Mississippi River valley, (2) loess of the Great Plains region, (3) loess of the Snake River Plain, (4) the Palouse loess, and (5) loess found over diverse terrains in Alaska. Far less work has been done on the geochemistry of loess of the Snake River Plain and the Palouse region, so the focus of the present paper will be on the other three regions.

The greater Mississippi River valley loess region includes not only landscapes of that major drainage, but also those landscapes surrounding tributaries to this river, such as the Ohio River, Wabash River, Illinois River, and Missouri River (Fig. 7). Loess is found along all of these rivers. What these rivers have in common is that all were carriers of outwash from the Laurentide Ice Sheet that covered much of the northeastern two-thirds of the continent during successive glacial periods of the Quaternary (Figs. 6-8). In the late 19th century, T.C. Chamberlin introduced what is now a classical model for the origin of loess in this region. Chamberlin (1897) proposed that loess accumulated as a result of the aeolian transport of silt from valley-train outwash, in turn derived from the till of the Laurentide Ice Sheet. Outwash from this ice sheet filled the valleys of the Missouri River, Mississippi River, Illinois River, Wabash River and Ohio River during the most recent glacial periods. This model of glacial outwash as the major supplier of loess in the greater Mississippi River drainage basin has withstood the test of time for many decades (see reviews in Ruhe (1983), Bettis et al. (2003), and Muhs (2013a)).

Despite the common, glaciogenic origin of loess throughout the greater Mississippi River drainage basin, loess composition differs from place to place within the region. Compositional variability reflects lithologically diverse terrains that the different lobes of the Laurentide Ice Sheet traversed (Fig. 8). For example, the Ontario-Erie, Huron, Lake Michigan, and Green Bay lobes of the ice sheet (Fig. 7) eroded particles from terrains dominated by Paleozoic carbonates (mainly dolomites) and Paleozoic shales, with smaller amounts of Precambrian crystalline rocks (Frye et al., 1969; Mickelson et al., 1983; Grimley, 2000). The Superior-Rainy lobes eroded terrains dominated by Precambrian igneous and metamorphic rocks, with smaller contributions from other rocks. Finally, the Des Moines and James lobes of the Laurentide Ice Sheet eroded Precambrian igneous and metamorphic rocks, large amounts of Cretaceous shale, and smaller amounts of Paleozoic limestone and dolomite (Frye et al., 1969; Hallberg and Kemmis, 1986). The result of these different contributing bedrock sources is that till, outwash, and loess in the region all have varying abundances of quartz, feldspars, carbonate minerals, and clay minerals.

The second large loess belt within central North America is the Great Plains region. In the present paper, this region is defined as the area west of the Missouri River that was not covered by the Laurentide Ice Sheet and includes the western parts of North and South Dakota, Nebraska, Kansas and eastern Colorado (Fig. 7). Although loess bodies east and west of the Missouri River are more or less continuous as depicted in generalized maps of loess distribution, isotopic, geochemical and mineralogic studies have shown that loess in the Great Plains has a very different origin from that of the Mississippi River valley. Studies by Aleinikoff et al. (1999, 2008), Muhs et al. (1999, 2008a), and Yang et al. (2017) show that loess in the Great Plains is derived partly from fluvial sources such as the Platte River system (Fig. 7). The Platte River and its tributaries derive most of their sediment from Precambrian crystalline rocks of the Rocky Mountains farther west in Colorado and Wyoming. However, a more important source of Great Plains loess is derived from Tertiary siltstone of the White River Group. This group (a larger geologic unit consisting of one or more formations) has an extensive distribution in the States of Colorado, Wyoming, Nebraska, and South Dakota and is dominated, by virtue of its volcaniclastic origin, by silt-sized particles. Thus, the issue of silt particle formation by either glacial or non-glacial processes does not apply here: silt-sized particles are inherited from the White River Group siltstone. Field studies have shown that some of the thickest last-glacial-aged loess is found in the Great Plains region (Swinehart et al., 1994; Mason, 2001). In both the Mississippi River valley and Great Plains, the history of loess deposition is punctuated by periods of soil formation from at least the middle Pleistocene (Fig. 9).

The third major loess region within North America that is discussed here is loess of Alaska (Figs. 6 and 10). As is the case with Central Asia, plate tectonic processes set the stage for the geologic evolution of Alaska (Plafker and Berg, 1994). Movement of the Pacific plate northward brought about subduction below the North American plate and successive accretion of lithologically diverse terranes that built the complex basins and mountain ranges that comprise the region. Subduction continues to this day, with the result that there are active volcanoes found in the southern part of the region, on the Alaskan Peninsula and the Aleutian Islands, stretching almost to Asia. In southeastern Alaska, subduction was strongest about $26 \mathrm{Ma}$ and has weakened since that time (Winkler, 2000).

There are a number of rugged mountain ranges in Alaska, including the Brooks Range in the north, the Alaska Range and Chugach Mountains in the south, and the Wrangell-St. Elias Ranges in the southeastern part of Alaska, continuing into adjacent Canada (Fig. 10). The interior of the region is occupied by large basins, with smaller areas of uplands that do not reach the elevations of the major mountain ranges. Glaciation in Alaska is the result of (1) its relatively high latitude; (2) high elevations in the Brooks Range, Alaska Range, Chugach Moutains, and Wrangell-St. Elias Range; and (3) abundant Pacific-derived moisture from the Aleutian low-pressure cell. The Brooks Range was extensively glaciated in the Pleistocene, though it is shielded from much of this moisture at present and thus there are currently only a very few, small glaciers (Hamilton, 1982). In contrast, the Alaska Range, Chugach Mountains, and Wrangell-St. Elias Mountains still receive abundant Pacific-derived moisture and have extensive glaciers, although they were much more widespread in the Pleistocene (Figs. 10 and 11). 


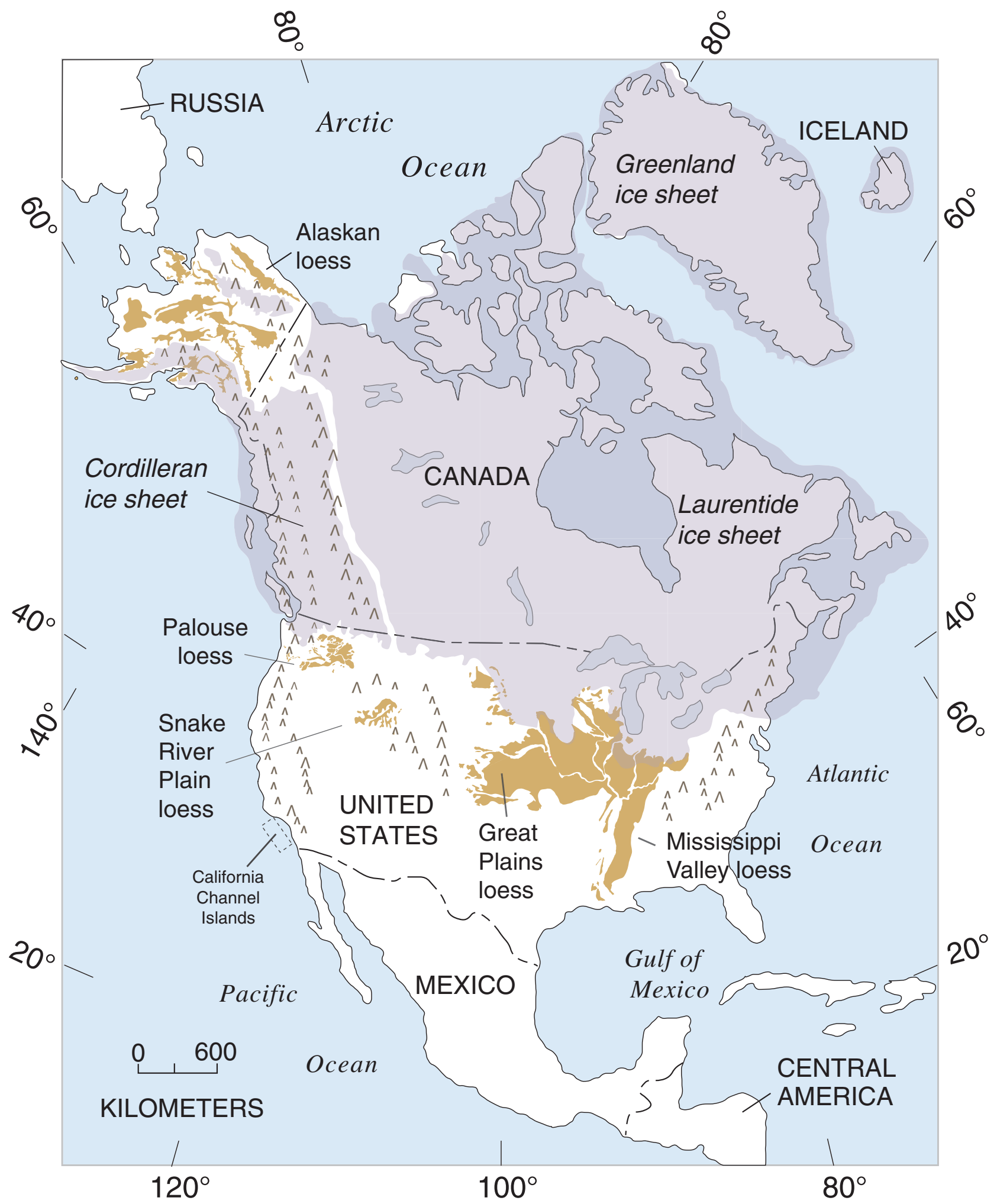

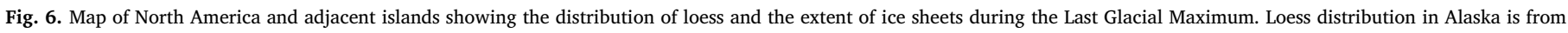

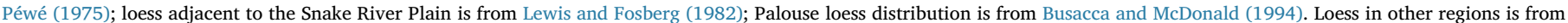
Bettis et al. (2003) and Muhs et al. (2013a) and sources therein. Extent of ice sheets at the last glacial maximum is taken from Dyke et al. (2002).

Most of the interior part of Alaska, between the Alaska Range and the Brooks Range, was not glaciated during the Pleistocene, and this is where the largest and thickest loess deposits are found (Fig. 10). The earliest loess in this part of Alaska is as old as $\sim 3.0 \mathrm{Ma}$ (Westgate et al., 1990), with continuing deposition through the Holocene (Muhs et al.,
2003). Loess is also found north of the Brooks Range, beyond the limit of glaciation on the Arctic Coastal Plain, on the unglaciated northern part of the Seward Peninsula, and in the southwestern part of the region. Holocene loess is accumulating today in the southern part of the region, following deglaciation of last-glacial-period ice. 


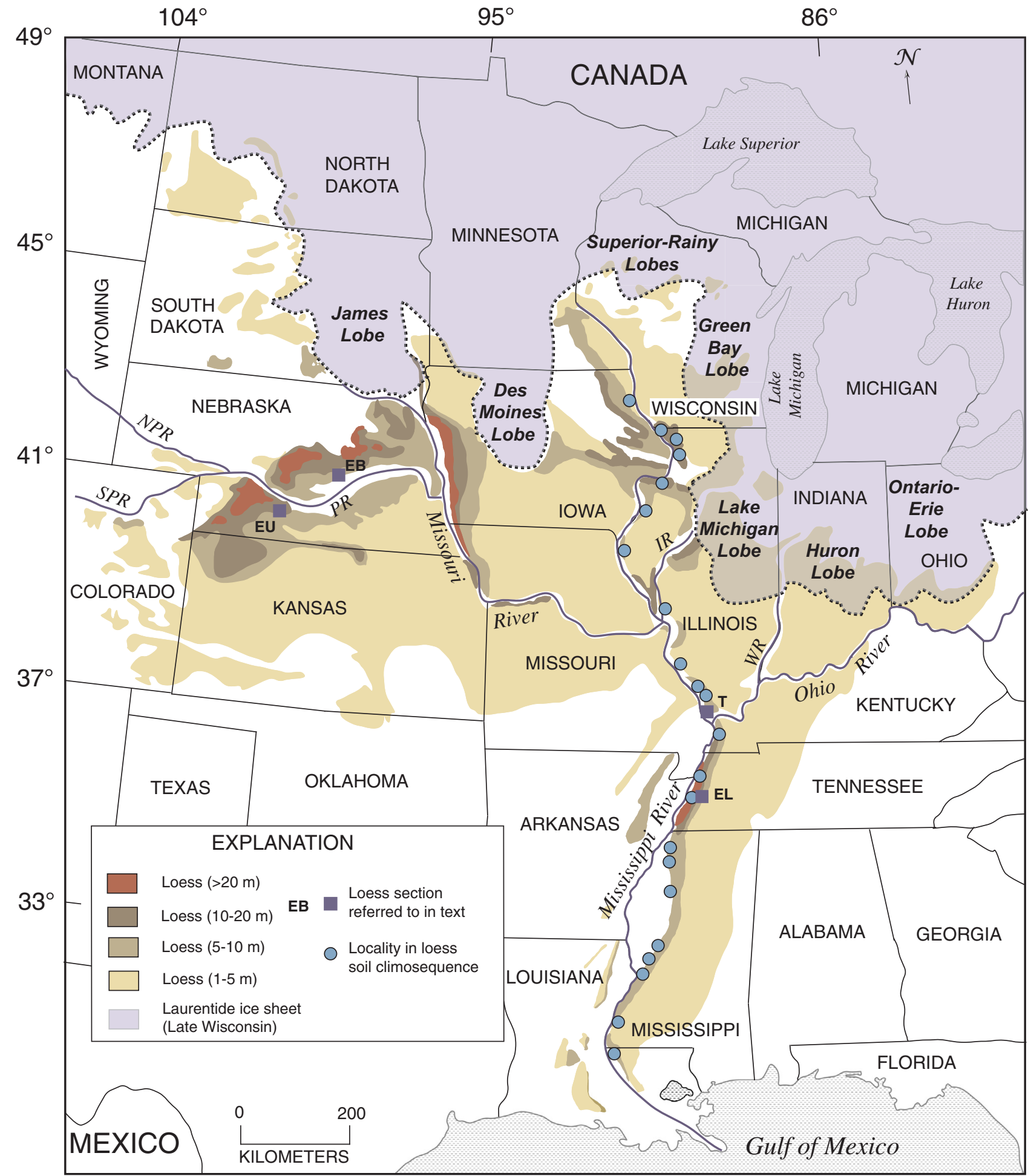

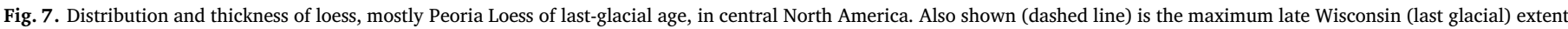

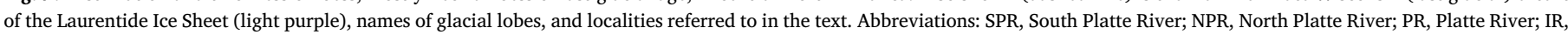

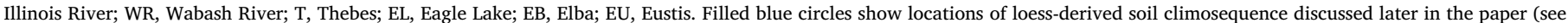

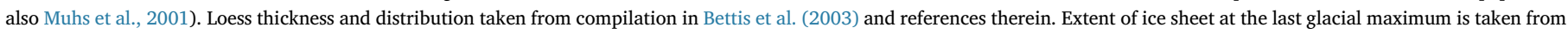
Dyke et al. (2002).

Rock types are highly variable in Alaska, as expected in a region consisting of accreted terranes. In the southern flanks of the Brooks Range, Paleozoic clastic sedimentary and metasedimentary rocks, limestone and dolomite, and Paleozoic and Mesozoic mafic volcanic rocks are found. The northern flanks of the Alaska Range are characterized by Precambrian and Paleozoic gneiss and schist, Paleozoic clastic sedimentary and metasedimentary rocks, Paleozoic limestone and dolomite, Tertiary clastic sedimentary rocks, and smaller amounts of Cretaceous granitic intrusions. Farther south, the Chugach Mountains are composed to a great extent of metasedimentary rocks with greenschist and amphibolite facies. Rocks of the Wrangell-St. Elias Mountains consist of diverse, Paleozoic to Quaternary volcanic rocks 


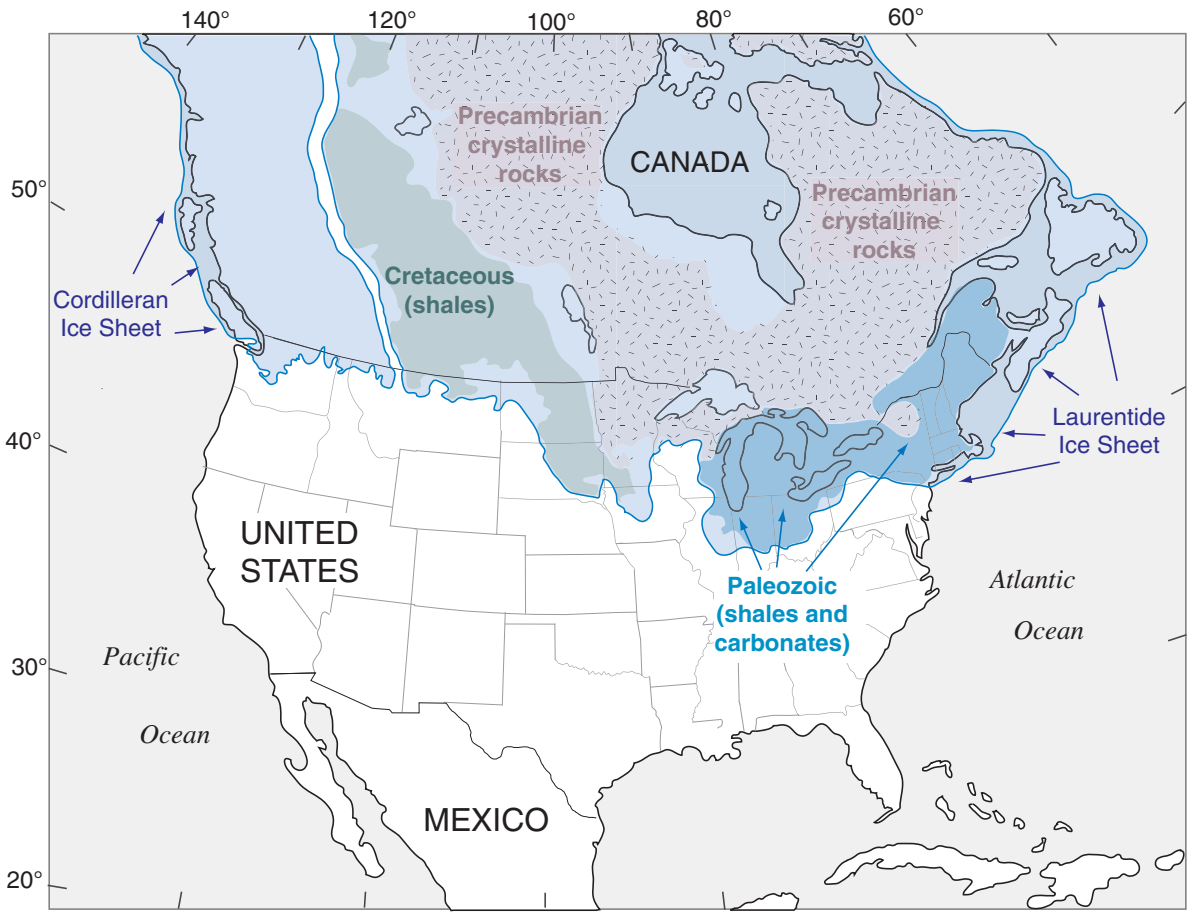

Fig. 8. Map showing principal bedrock types in North America that were eroded by the Laurentide Ice Sheet during the last glacial period. Bedrock is highly generalized from Reed et al. (2005). Extent of ice sheets at the last glacial maximum is taken from Dyke et al. (2002). (basalt, andesite, dacite), but also metavolcanic rocks and limestones.

Whereas there has been considerable debate about the issue of glacial versus desert loess in China, there is little doubt that silt production in Alaska is due to glacial grinding. The distinctive turquoise color from "rock flour" in Alaskan lakes within valleys that host glaciers contrasts strongly with the clear water in lakes where no glaciers exist. Analysis of suspended sediment data from streams in Alaska shows that sediment yields are positively correlated with the amount of glacial cover in drainage systems (Hallet et al., 1996). Indeed, Hallet et al. (1996) show that basins with $\geq 30 \%$ glacier cover have sediment yields about an order of magnitude higher than the amount of sediment in basins without glaciers. During the autumn, when stream discharge is low in Alaska (Crusius et al., 2011; Muhs et al., 2013b), dust storms from floodplains of rivers that drain glaciers are common and suspended dust can travel hundreds of kilometers from its source (Fig. 11).

\section{Major element geochemistry of loess and implications for origins}

\subsection{Loess as a proxy for average upper continental crust composition}

A concept that has been put forward periodically over the past three decades is that loess is a broad natural sample of the Earth's upper continental crust (Taylor et al., 1983; Taylor and McLennan, 1985, 1995, 2009; Liu et al., 1993; Gallet et al., 1996, 1998; McLennan, 2001). The rationale behind this concept is that erosion of broad areas by continental ice sheets (as was the case in North America and Europe) or fluvial/glacial erosion of mountainous terrain with diverse rock types surrounding large desert basins (as in many parts of Asia), followed by regional- or continental-scale aeolian transport provides a widespread and representative sampling of many upper crustal rock types. In principle, then, such a natural sampling process could yield a composition that is close to average upper continental crust. In broadscale comparisons of rock compositions, e.g., oceanic crust vs. continental crust, this concept certainly has validity and has been a useful index for average upper crustal compositions. At a finer scale, loess composition has variability from region to region and that will become evident in both the major element geochemistry and trace element geochemistry discussions that follow. Indeed, it is emphasized that it is this variability that is of most use to Quaternary geologists and geomorphologists attempting to reconstruct paleoclimate from loess records.

\subsection{Major element geochemistry as a function of mineralogy in loess}

The concentrations of major elements in loess are a reflection of the minerals present in the sediments. Based on studies from a number of regions within both Asia and North America, the most common minerals found in loess are quartz, plagioclase, K-feldspar, micas, chlorite, amphiboles, calcite, dolomite, and phyllosilicate clay minerals (Frye et al., 1962, 1968; Péwé and Journaux, 1983; Liu, 1988; Eden et al., 1994; Grimley et al., 1998; Grimley, 2000; Muhs and Bettis, 2000; Sun, 2002a, 2002b; Muhs et al., 2003, 2008a, 2013b, 2016; Sun et al., 2007; Jeong et al., 2008). Almost all loess deposits also contain small amounts of heavy minerals, but identification of these species is difficult because of the small particle size and low abundances.

Concentrations of complementary major elements on bivariate plots display some of the common mineralogical differences between loess bodies derived from distinctive source regions (Fig. 12). Phyllosilicate clay minerals (smectite, mica, kaolinite, chlorite) are relatively rich in $\mathrm{Al}$ and often are also enriched in $\mathrm{Fe}$ (certain smectites and chlorites). Thus, concentrations of $\mathrm{Al}_{2} \mathrm{O}_{3}$ and $\mathrm{Fe}_{2} \mathrm{O}_{3}$ are frequently positively correlated, as is seen in the plots for loess from Yakutia (northern Siberia), the Chinese Loess Plateau, and Tajikistan (Fig. 12a). In North America, this is also apparent in the concentrations of $\mathrm{Al}_{2} \mathrm{O}_{3}$ and $\mathrm{Fe}_{2} \mathrm{O}_{3}$ (except for Mississippi River valley loess). The lower values for both $\mathrm{Al}_{2} \mathrm{O}_{3}$ and $\mathrm{Fe}_{2} \mathrm{O}_{3}$ in Mississippi River valley loess are due primarily to dilution by high amounts of carbonate minerals, calcite and dolomite, as seen in concentrations of $\mathrm{CaO}$ and $\mathrm{MgO}$ (Fig. 12b). Central Alaska loess lacks significant amounts of carbonate minerals (Fig. 12b), but is rich in chlorite and mica in both silt and clay sizes (Muhs et al., 2003, 2008c), so $\mathrm{CaO}$ and $\mathrm{MgO}$ are lower and $\mathrm{Al}_{2} \mathrm{O}_{3}$ and $\mathrm{Fe}_{2} \mathrm{O}_{3}$ are higher than in Mississippi River valley loess. Loess in the Great Plains region of Nebraska contains carbonates, but not in amounts as abundant as in the Mississippi River valley, so it has intermediate values of concentrations of $\mathrm{Al}_{2} \mathrm{O}_{3}$ and $\mathrm{Fe}_{2} \mathrm{O}_{3}$. Plots of $\mathrm{CaO}$ vs. $\mathrm{MgO}$ for Asian loess bodies indicate that loess in Tajikistan has very high amounts of carbonate minerals, consistent with data in Dodonov et al. (2006) whereas loess in Yakutia 


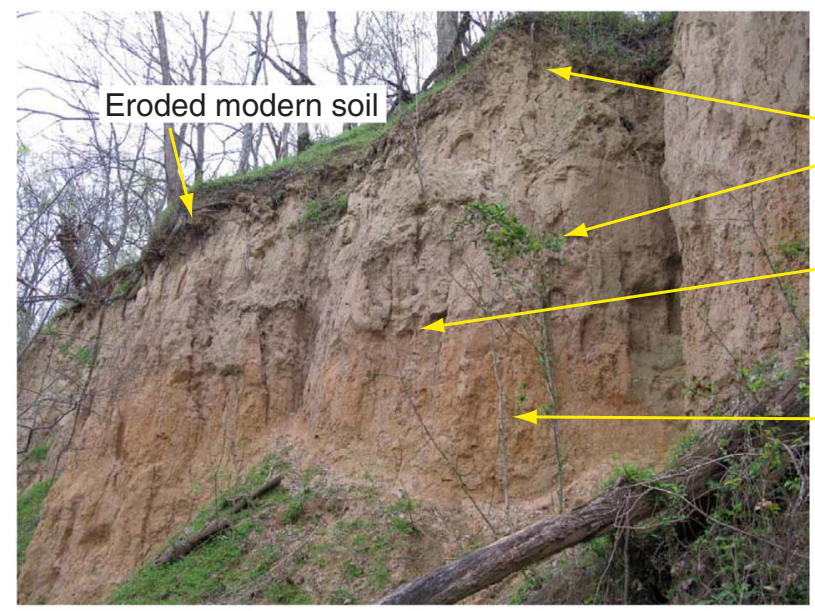

(b) Elba,

Nebraska:

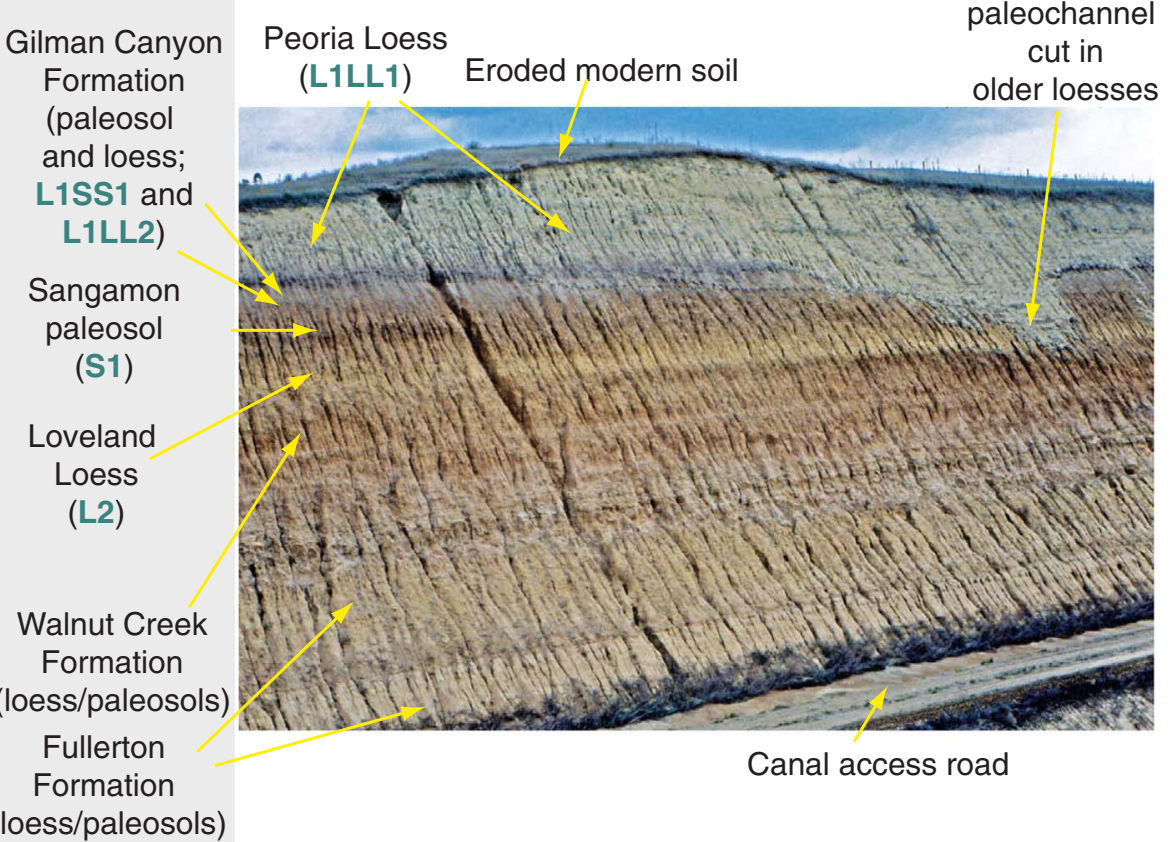

(a) Eagle Lake, Tennessee:

Peoria Loess (L1LL1)

Farmdale Soil and Roxana Loess (L1SS1 and L1LL2)

Sangamon paleosol (S1) in Loveland Loess (L2)
Peoria Loess filling leochannel cut in der loesses
Fig. 9. Photographs of loess exposures in the Mississippi River valley (a) and Great Plains region of North America (b). See Fig. 7 for locations. (a) Eagle Lake, Tennessee; (b) near Elba, Nebraska. Standard stratigraphic unit names for loess and paleosols are given in both photographs, but probable equivalent Chinese loess units are given in bold green type in parentheses. Both photographs by D.R. Muhs. has low amounts of carbonate minerals, consistent with mineralogical data reported by Péwé and Journaux (1983). In the Chinese Loess Plateau, sediments have intermediate amounts of carbonate minerals (Eden et al., 1994), which is in agreement with intermediate concentrations of $\mathrm{CaO}$ and $\mathrm{MgO}$ (Fig. 12b). Plots of $\mathrm{Na}_{2} \mathrm{O}$ vs. $\mathrm{K}_{2} \mathrm{O}$ show that loess bodies are also distinct from one another for abundances of plagioclase (and to some extent, hornblende), as proxied by $\mathrm{Na}_{2} \mathrm{O}$ and $\mathrm{K}$ feldspar and micas, as proxied by $\mathrm{K}_{2} \mathrm{O}$ (Fig. 12c).

Although loess is dominated by silt and is, by comparison with many other sediments, relatively well sorted, it does of course contain a range in particle sizes. Most loess deposits contain some sand $(>50 \mu \mathrm{m})$, some clay $(<2 \mu \mathrm{m})$, and a variable spectrum of particles within the silt-sized class in between. This raises an important issue: does mineralogy (and therefore also geochemistry) change as a function of particle size in loess?

Two studies indicate that mineralogy does indeed vary between different particle size classes in loess. Eden et al. (1994) studied deposits on the Chinese Loess Plateau and did separate mineralogical analyses of coarse silts $(60-20 \mu \mathrm{m})$, fine silts $(20-2 \mu \mathrm{m})$, and clays $(<2 \mu \mathrm{m})$. Their results indicate that within the two silt fractions, quartz and feldspars are highest within the coarse silt fraction and micas and chlorite are highest within the fine silt fraction. A more recent study by Yang et al. (2006) is a detailed geochemical analysis of sediments, also from the Chinese Loess Plateau, showing concentrations of major elements within six particle size classes, including sands, clays, and four size ranges of silts (Fig. 13). Consistent with the results of Eden et al. (1994), both $\mathrm{SiO}_{2}$ and $\mathrm{Na}_{2} \mathrm{O}$ show increasing concentrations with increasing particle diameter classes, indicating higher abundances of quartz and plagioclase in the coarser fractions. Concentrations of $\mathrm{Al}_{2} \mathrm{O}_{3}$ and $\mathrm{Fe}_{2} \mathrm{O}_{3}$ show decreases with increasing particle size classes, indicating that these elements are likely concentrated in phyllosilicate clay minerals, as discussed above. Some $\mathrm{Fe}_{2} \mathrm{O}_{3}$ may also reflect the presence of chlorite, which is also proxied by $\mathrm{MgO}$ and shows a decrease in concentrations with coarser size classes. Finally, $\mathrm{K}_{2} \mathrm{O}$ shows decreasing abundances with increasing particle size, suggesting that this element is most likely representing clay- and fine-silt-sized micas. The results of this study are highly significant, as they demonstrate the importance of understanding both the particle size distribution of a loess body as well as its mineralogy before geochemical interpretations can be made with confidence. 


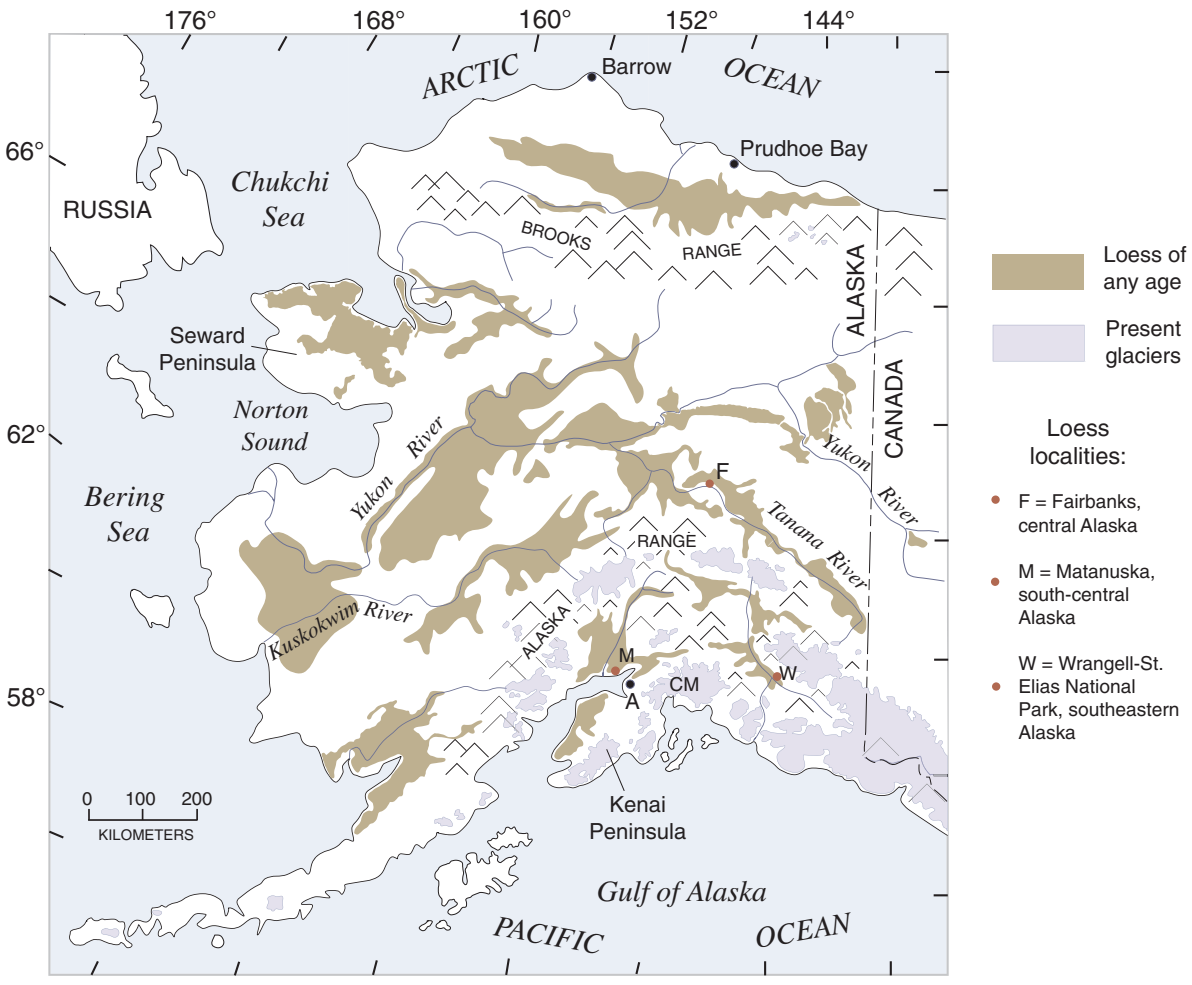

Fig. 10. Map showing the distribution of loess deposits (brown) in Alaska, compiled from Hopkins (1963) and Sainsbury (1972) for the Seward Peninsula, Williams (1962), Foster et al. (1983), and Weber et al. (1997) for areas along the Yukon River, and Péwé (1975) for all other parts of the region. A, Anchorage; CM, Chugach Mountains. Most mapping from these sources has been field checked by the author. Also shown is the present extent of glaciers (blue) in the region, taken from Péwé (1975) and Brown et al. (1997).

\subsection{Spatial variability of major element geochemistry in loess}

Many studies have demonstrated that loess in both Asia and North America shows significant changes in mean particle size as a function of distance downwind from what are inferred to be probable immediate sources (Smith, 1942; Frazee et al., 1970; Ruhe, 1983; Liu, 1988; Muhs and Bettis, 2000, 2003; Porter et al., 2001; Muhs et al., 2004; Ding et al., 2005). The most important trends, with respect to distance from a source, are a decrease in sand and coarse silt contents, decrease in mean particle size, and increase in fine silt and clay contents. Based on the discussion above on how different minerals (and therefore major elements) tend to be partitioned into specific size classes, one could expect that there should be spatial variability in major element concentrations. Eden et al. (1994) explored this on the Chinese Loess Plateau and found that in a north-to-south transect from the Mu Us Desert's southern margin across the plateau (Fig. 2), $\mathrm{SiO}_{2}$ concentrations show decreases to the south and $\mathrm{Al}_{2} \mathrm{O}_{3}, \mathrm{Fe}_{2} \mathrm{O}_{3}, \mathrm{TiO}_{2}$, and $\mathrm{K}_{2} \mathrm{O}$ show increases. Other elements display either weak trends or no trends. Based on the relations between these elements and particle sizes shown in Fig. 13, decreases in $\mathrm{SiO}_{2}$ concentrations are likely due to the north-to-south decreases in sand and coarse silt content (dominated by quartz) and the increases in $\mathrm{Al}_{2} \mathrm{O}_{3}, \mathrm{Fe}_{2} \mathrm{O}_{3}, \mathrm{TiO}_{2}$, and $\mathrm{K}_{2} \mathrm{O}$ concentrations are a function of the northto-south increase in fine silt and clay contents (dominated by micas, chlorite, and phyllosilicate clay minerals). Thus, the trends reported by Eden et al. (1994) are consistent with the spatial trends in particle sizes for the Chinese Loess Plateau reported by Liu (1988) and Ding et al. (2005). Geochemical data for a north-to-south transect across the Chinese Loess Plateau were also reported by Ding et al. (2001), although for a fewer number of sites. Their data also show a downwind decrease in $\mathrm{SiO}_{2}$ concentrations, related to quartz-dominated sand and coarse silt, along with a downwind increase in $\mathrm{Fe}_{2} \mathrm{O}_{3}$, related to greater abundances of clay minerals downwind (Fig. 14). Surprisingly, $\mathrm{Al}_{2} \mathrm{O}_{3}$ concentrations, expected to increase to the south, display only a weak trend. An unexpected trend is a significant increase in $\mathrm{CaO}+\mathrm{LOI}$ (where LOI is loss on ignition) from north to south (Fig. 14). The sum of $\mathrm{CaO}$ + LOI can be a proxy for calcite (and perhaps dolomite to a lesser extent) and indicates that calcite content could be greater in the southern part of the Chinese Loess Plateau. Another explanation might be an increase in anorthite (Ca-plagioclase) and/or Ca-bearing pyroxenes in a downwind direction.

Loess in North America shows some of the same geochemical trends away from a hypothesized source as those seen on the Chinese Loess Plateau. Muhs and Bettis (2000) examined last-glacial-aged ("Peoria" Loess; equivalent to L1-1 Loess in Chinese stratigraphic nomenclature) loess along a transect east of the Missouri River in western Iowa. As seen in Fig. 7, loess in this area is thickest adjacent to the Missouri River and thins eastward (Hallberg et al., 1991), consistent with a decrease in mean particle size in the same direction (Ruhe, 1983; Muhs and Bettis, 2003). These observations imply a Missouri River floodplain source, as per the classic model proposed by Chamberlin (1897) for North American loess origins. As is the case with the Chinese Loess Plateau, $\mathrm{Al}_{2} \mathrm{O}_{3}, \mathrm{Fe}_{2} \mathrm{O}_{3}, \mathrm{TiO}_{2}$, and $\mathrm{K}_{2} \mathrm{O}$ all show increases from west to east, consistent with downwind increases in fine-grained particles that are dominated by micas and other phyllosilicate clay minerals (Fig. 15 shows two of these trends). Surprisingly, unlike the Chinese Loess Plateau, concentrations of $\mathrm{SiO}_{2}$ show a modest increase from west to east, but while significant, the degree of explanation $(\sim 33 \%)$ is not high (Fig. 15).

In their transect in western Iowa, Muhs and Bettis (2000) also report that $\mathrm{CaO}, \mathrm{MgO}$, and $\mathrm{Sr}$, all elements found in carbonate minerals, show decreases with distance east of the Missouri River. This same mineralogical trend is shown in Fig. 15 as $\mathrm{CaO}+\mathrm{LOI}(\%)$ versus distance east of the Missouri River, in order to make direct comparisons with the Chinese Loess Plateau. This proxy for calcite also shows an eastward decrease. More than seven decades ago, Smith (1942), studying Peoria Loess in the State of Illinois (Fig. 7) postulated that with lower rates of sedimentation as one moves away from a source, one should expect increased syndepositional weathering of carbonate minerals. In this concept, distal areas of loess accumulation have sedimentation rates that are low enough for carbonate leaching to keep pace with particle accretion. With the recognition that Peoria Loess in Illinois contains distinct mineralogical zones, including zones with high and low amounts of detrital carbonate grains (Frye et al., 1968), some subsequent workers (e.g., Fehrenbacher, 1973; Kleiss, 1973) rejected 


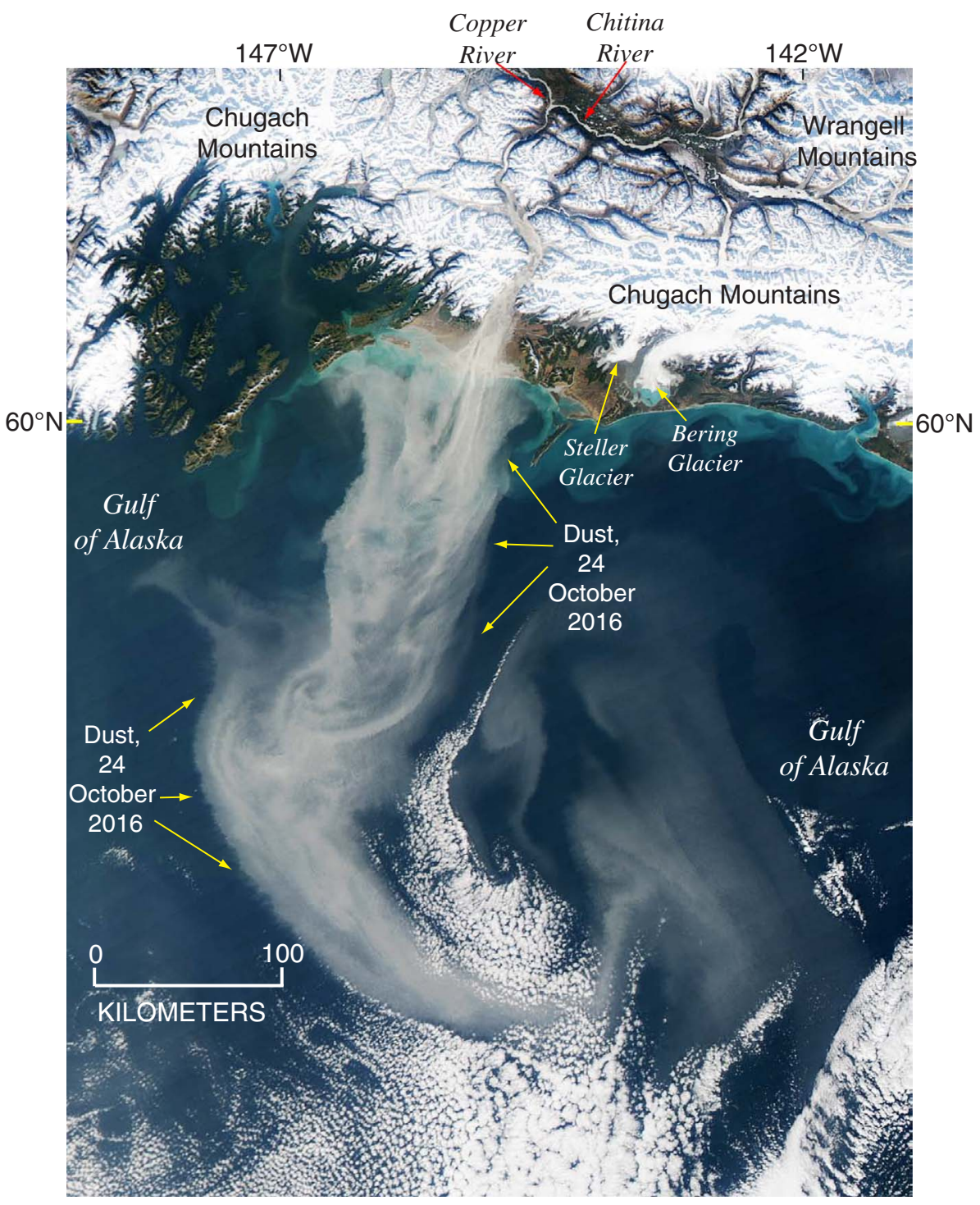

Fig. 11. MODIS image of southern Alaska and the Gulf of Alaska, showing glaciogenic dust in transit from the Copper River floodplain and reaching points hundreds of kilometers south on 24 October 2016. Dust storms such as this one typically occur in autumn, when river discharge is low (see Crusius et al., 2011). Image acquired from the Aqua satellite and is courtesy of MODIS Land Rapid Response Team at NASA GSFC.

Smith's (1942) model. Nevertheless, the data from western Iowa and similar data reported by Muhs et al. (2008a) from northeastern Nebraska seem to support Smith's (1942) model.

These considerations, therefore, raise some interesting questions about the observed trend of increasing carbonate contents as a function of distance south of the Mu Us Desert on the Chinese Loess Plateau (Fig. 14). There is little question that sedimentation rates decrease to the southeast away from the Mu Us Desert (see Porter et al., 2001; their Fig. 6b), so it could be anticipated that the potential for syndepositional leaching exists on this basis alone. In addition, mean annual precipitation increases in the same direction (see Porter et al., 2001; their Fig. 4b), which would enhance the already favorable setting for syndepositional carbonate leaching. Thus, the observation of geochemical data indicating possible higher carbonate mineral content southward across the Chinese Loess Plateau (Fig. 14) is unexpected. One possible explanation is that there is a secondary, carbonate-rich source of dust in the southern part of the Loess Plateau that does not affect the northern part of the region, but this requires further testing.

\subsection{Use of major element geochemistry to infer source rocks for loess}

Because loess is ultimately derived from rocks with diverse compositions, much can be learned about a loess body's origins by comparing its major element geochemistry with that of common rock types.
Garrels and Mackenzie (1971) provide two useful geochemical arrays in this regard. Although these graphical presentations were designed for geochemical classification of sedimentary rocks and to trace their compositional evolution, they serve as highly informative plots for ascertaining likely source materials for loess. Loess from dominantly basaltic Iceland, while strictly speaking is not part of either Asia or North America, is included in the discussions here because it illustrates how an end-member composition appears on these plots.

The first of the Garrels and Mackenzie (1971) plots considers the geochemistry of three of the most important sedimentary rocks, shales (and slates derived from shales), carbonates (limestone and dolomite), and sandstones, as well as a felsic-mafic continuum of igneous rocks (Fig. 16). The horizontal axis is $\log \left[\left(\mathrm{CaO}+\mathrm{Na}_{2} \mathrm{O}\right) / \mathrm{K}_{2} \mathrm{O}\right]$, essentially a measure of carbonates plus plagioclase to $\mathrm{K}$-feldspar. The vertical axis is $\log \left(\mathrm{SiO}_{2} / \mathrm{Al}_{2} \mathrm{O}_{3}\right)$, essentially a measure of quartz to feldspars and clay minerals. Thus, limestones and dolostones, with their high calcite and dolomite contents (and therefore high Ca contents), will plot far to the right, whereas sandstones, with their high quartz contents (and therefore high Si contents) will plot near the top. Shales, with their high mica and clay mineral contents (and therefore high $\mathrm{K}$ and $\mathrm{Al}$ contents) will plot to the left but lower than sandstones. The average plutonic rock plots approximately where the fields for shales and sandstones nearly intersect; basalts fall to the right of this and granites fall to the left (Fig. 16). 
(a) Clay minerals:
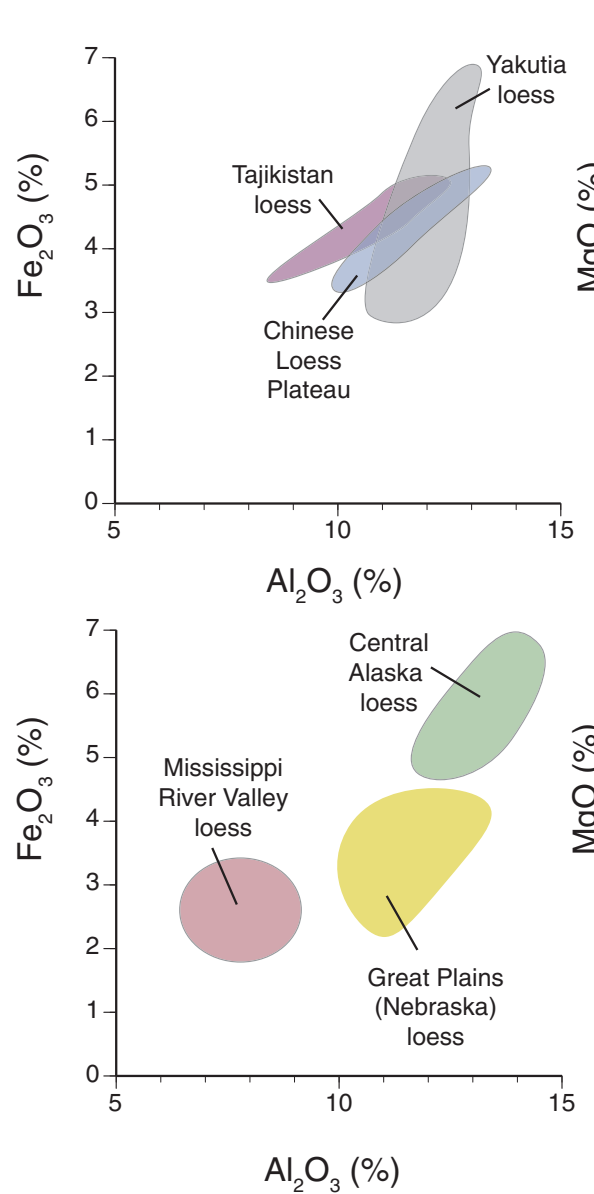

(b) Carbonate minerals:

(c) Feldspars and micas:
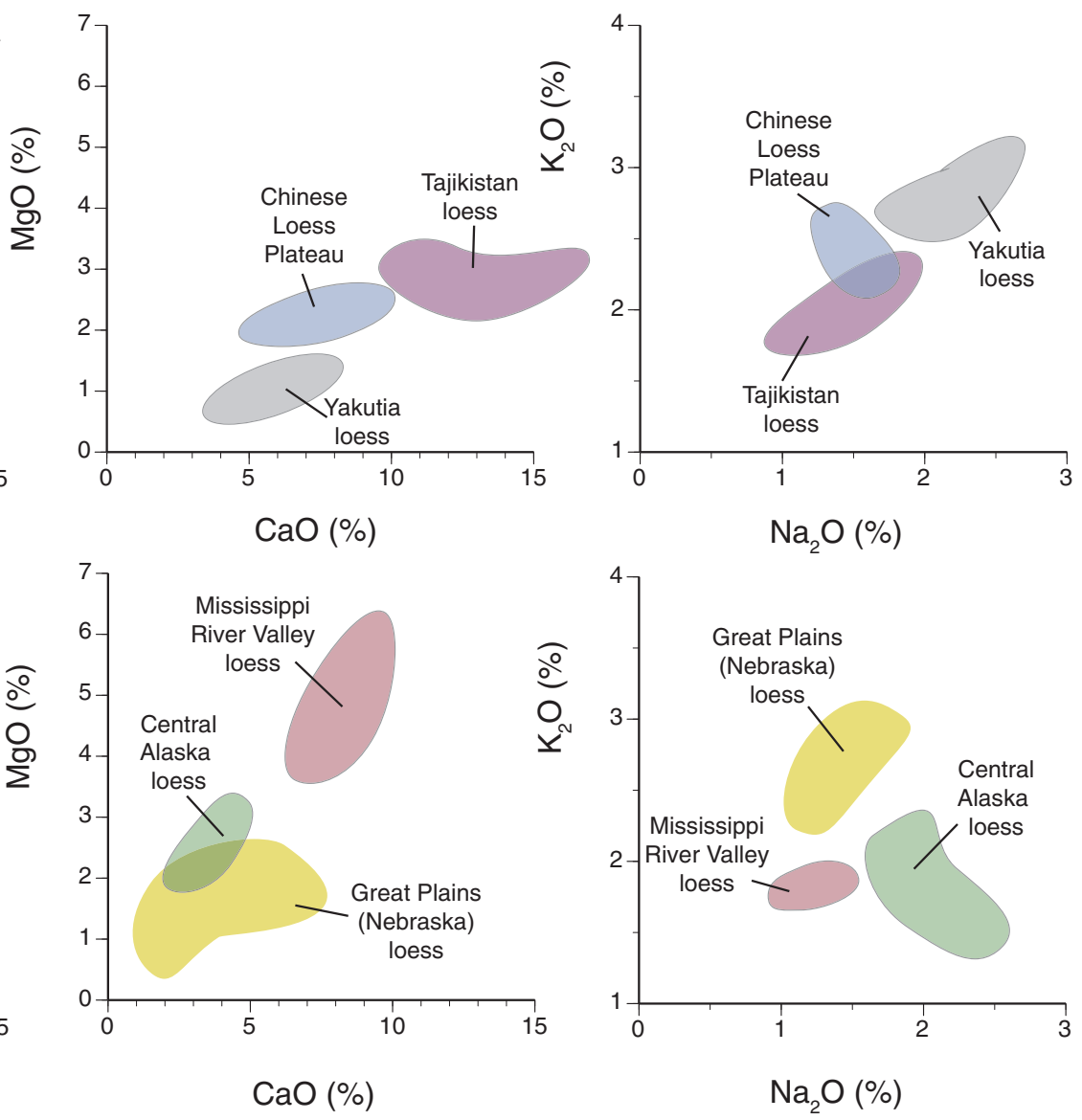

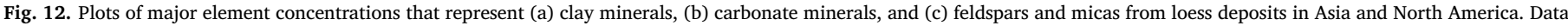

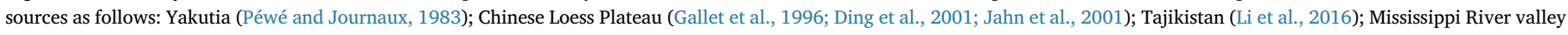
loess (Pye and Johnson, 1988; Muhs et al., 2001); central Alaska loess (Muhs et al., 2003, 2008c); Great Plains loess (Muhs et al., 2008a).

Because loess particles have a particle size distribution dominated by silts, between the modal particle sizes of sandstones and shales, it can be hypothesized that they ought to plot close to the intersection of these two fields. Results for a wide variety of loess bodies indicate that this is largely true (Fig. 16). Loess from Yakutia, the Chinese Loess Plateau, central Alaska, and the Great Plains of Nebraska plot very close to the composition of average plutonic rocks, suggesting that rocks with an average upper crustal composition (i.e., close to a granodiorite) were important suppliers to these loess bodies (Fig. 16a-c). Not surprisingly, many samples of loess from Iceland plot close to the average basalt value, but many points do not plot right on the position of average basalt (Fig. 16a). However, the low $\mathrm{Na}_{2} \mathrm{O}$ values in some Icelandic loess could be due to input from felsic volcanic rocks, which do occur in Iceland despite the basalt-dominated nature of the island (Thordarson and Larsen, 2007; Jakobsson et al., 2008). Moreover, because much of Iceland's basalt is tholeiitic, it is more "primitive" and therefore lower in $\mathrm{Na}_{2} \mathrm{O}$ (Jakobsson et al., 2008). Loess from Tajikistan, southeastern Alaska, and to a lesser extent, the Mississippi River valley plot to the right of the fields for both sandstone and shale, in the direction of the carbonate rocks field, indicating that there have been contributions from limestones and/or dolomites to these loess bodies (Fig. 16b-d). Great Plains loess and Mississippi River valley loess plot well above the field for shale, indicating that mica-rich rocks were perhaps not as important as contributing source rocks compared to loess from Yakutia, the Chinese Loess Plateau, and central Alaska (but see discussion below).

The second compositional plot from Garrels and Mackenzie (1971) compares $\mathrm{K}_{2} \mathrm{O} / \mathrm{Al}_{2} \mathrm{O}_{3}$ versus $\mathrm{Na}_{2} \mathrm{O} / \mathrm{Al}_{2} \mathrm{O}_{3}$ (Fig. 17) as a measure of relative contributions from felsic rocks (granites and rhyolites) versus mafic rocks (basalts and gabbros). Sediments that plot to the right have greater contributions from felsic sources and those with greater contributions from mafic sources will plot to the left. The vertical axis is a measure of the relative contributions from igneous rocks versus shales. The shale trend line is an empirically derived graph showing a range of low- $\mathrm{Na}_{2} \mathrm{O}$, but high- $\mathrm{Al}_{2} \mathrm{O}_{3}$, fine-grained sedimentary or metasedimentary rocks that include shales, slates, pelites, schists, and phyllites. The shale trend line occurs below the field for igneous rocks because shales and other clastic sedimentary rocks have lower $\mathrm{Na}_{2} \mathrm{O}$ than igneous rocks due to a history of depletion of plagioclase by chemical weathering. Put another way, low- $\mathrm{Na}_{2} \mathrm{O}$ rocks, as shown here, are sedimentary rock source indicators. The curve trends downward and to the right indicating increasing amounts of $\mathrm{K}_{2} \mathrm{O}$ and decreasing $\mathrm{Na}_{2} \mathrm{O}$, and ends with illite, having a $\mathrm{Na}_{2} \mathrm{O} / \mathrm{Al}_{2} \mathrm{O}_{3}$ value of essentially 0.0 and a $\mathrm{K}_{2} \mathrm{O}$ / $\mathrm{Al}_{2} \mathrm{O}_{3}$ value of just a bit over 0.40 . Average plutonic rocks plot within the lower part of the igneous rock field, just above the highest $\mathrm{Na}_{2} \mathrm{O}$ / $\mathrm{Al}_{2} \mathrm{O}_{3}$ value on the shale trend line. Gallet et al. $(1996,1998)$ used these plots in their studies of loess from a variety of localities worldwide.

Several interesting observations can be made from loess bodies when viewed on a $\mathrm{K}_{2} \mathrm{O} / \mathrm{Al}_{2} \mathrm{O}_{3}$ versus $\mathrm{Na}_{2} \mathrm{O} / \mathrm{Al}_{2} \mathrm{O}_{3}$ plot. The first is that loess bodies in China have significantly different compositions in each region (Fig. 17a). Loess from northeastern China, near Harbin (Fig. 2) has significantly higher $\mathrm{Na}_{2} \mathrm{O} / \mathrm{Al}_{2} \mathrm{O}_{3}$ values than samples from the Loess Plateau, and the latter have higher $\mathrm{Na}_{2} \mathrm{O} / \mathrm{Al}_{2} \mathrm{O}_{3}$ values than loess samples collected near the Qinling Mountains. All three Chinese loess 


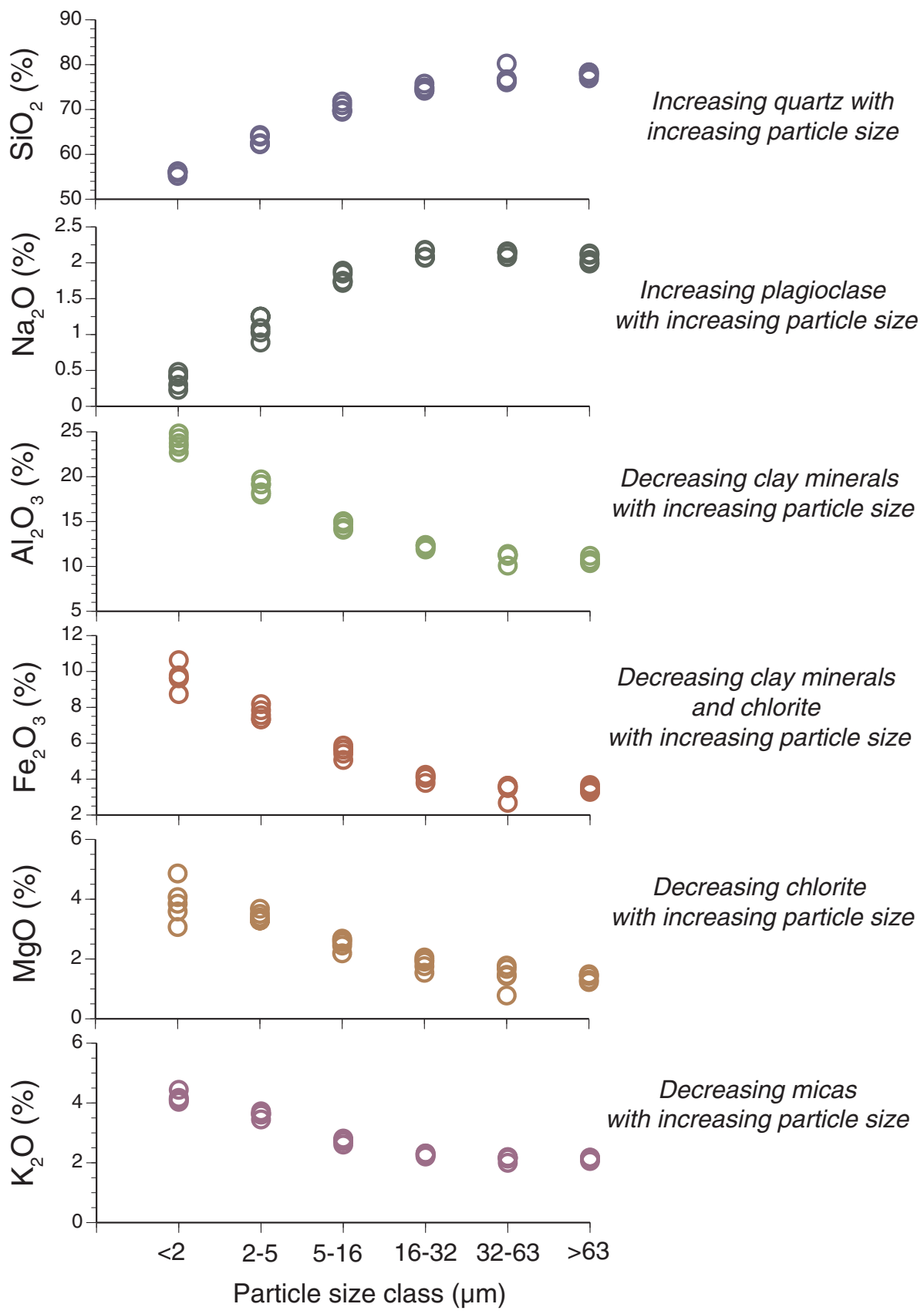

Fig. 13. Changes in concentrations of major elements as a function of particle size class from deposits (the L1 loess) on the Chinese Loess Plateau and interpretations of principal minerals each element represents. Plotted by the author from data in Yang et al. (2006). 

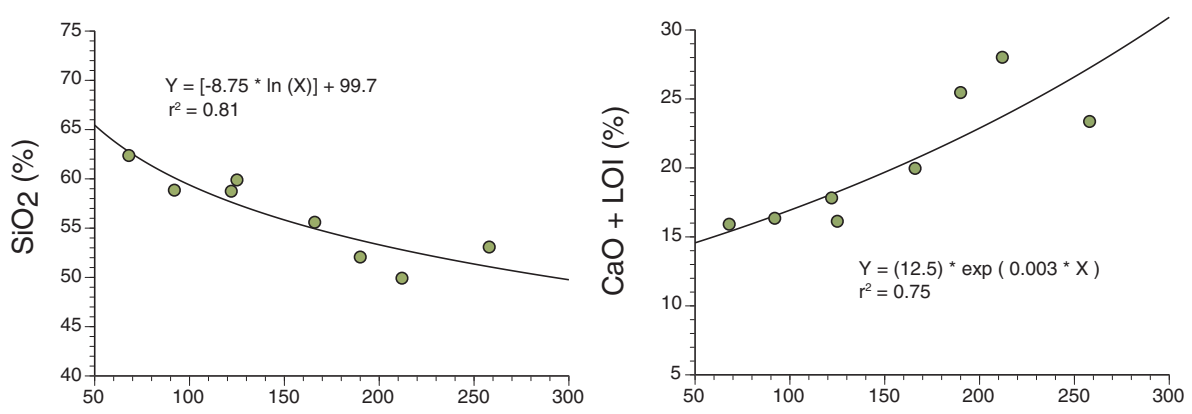

Fig. 14. Changes in concentrations of major elements in the L1 loess as a function of distance southeast of the southern boundary of the Mu Us Desert (Fig. 2). Regression equations, coefficients of determination, and distances south of the Mu Us Desert calculated by the author from data in Ding et al. (2001). Note: Ding et al. (2001) presented major element data on a volatile-free basis, but those values have been recalculated to include volatiles in the presentation given here.

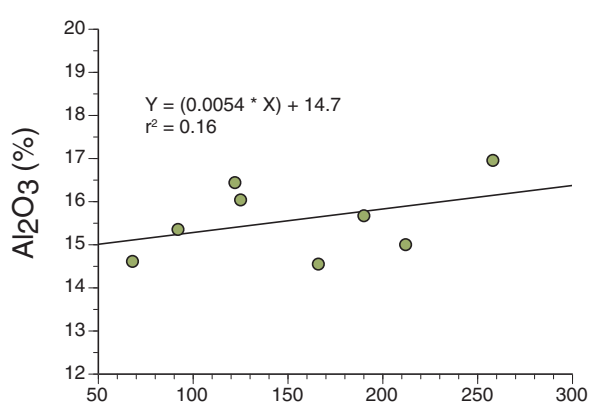

Distance southeast of the Mu Us Desert (km)

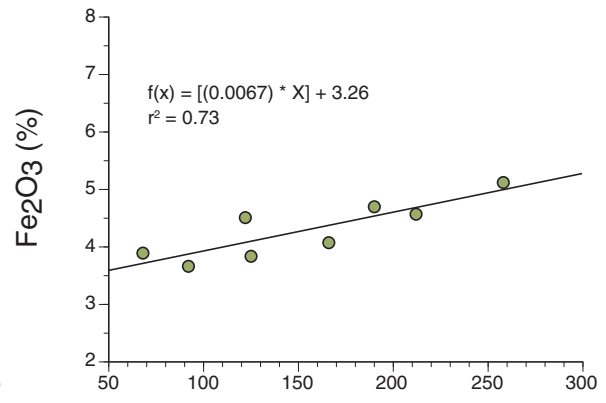

Distance southeast of the Mu Us Desert $(\mathrm{km})$ (a)

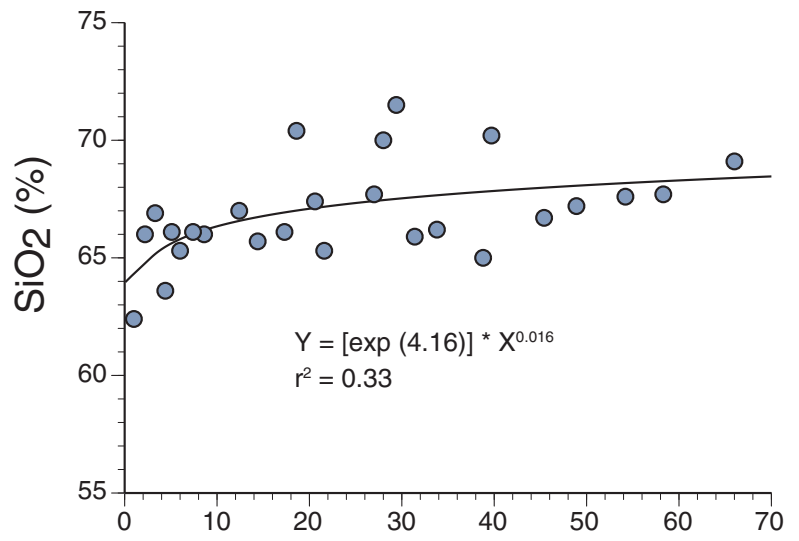

(b)

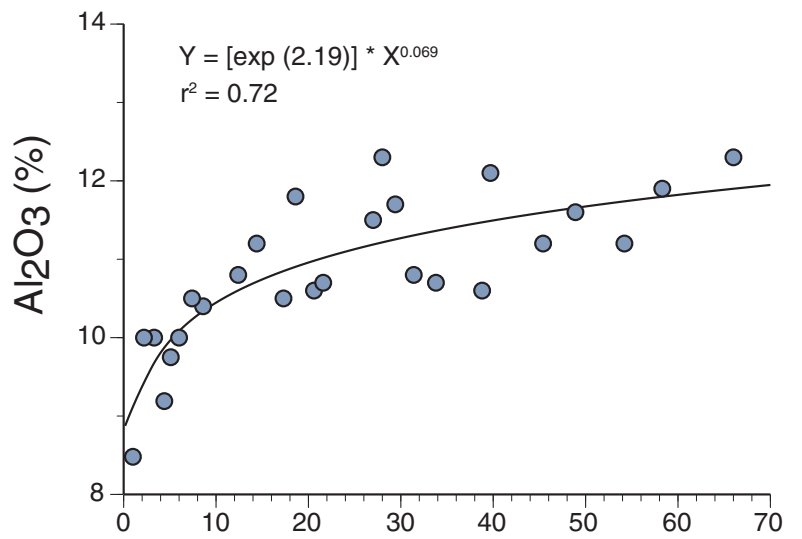

Distance east of the Missouri River bluffline in lowa $(\mathrm{km})$ (c)

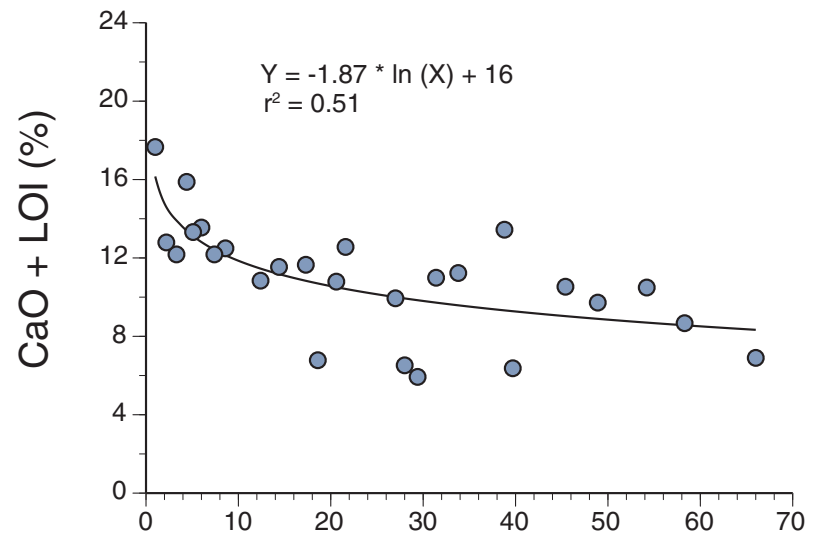

(d)

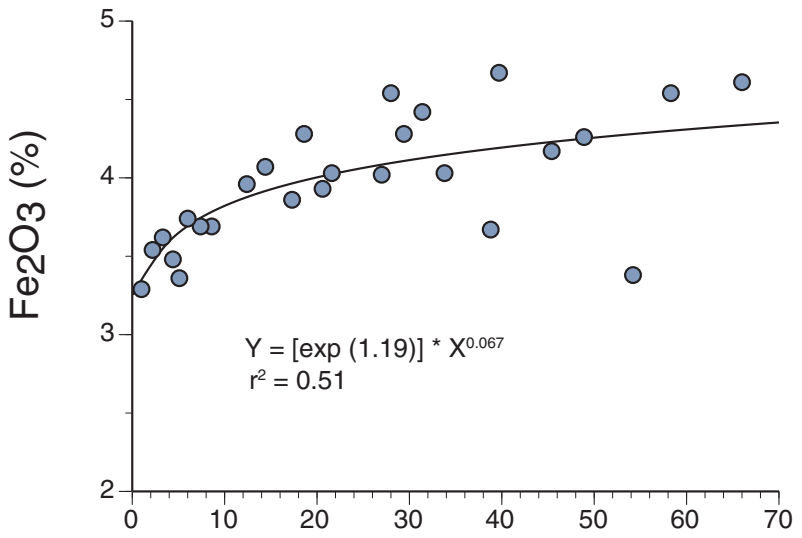

Distance east of the Missouri River bluffline in lowa $(\mathrm{km})$

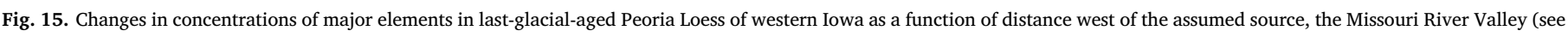
Fig. 7), showing the same elements as in Fig. 14. Data from Muhs and Bettis (2000). 
(a)

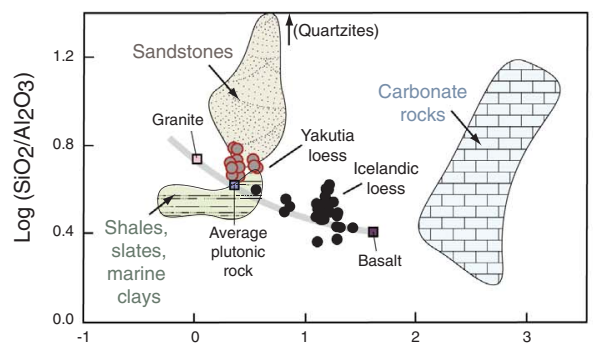

(b)
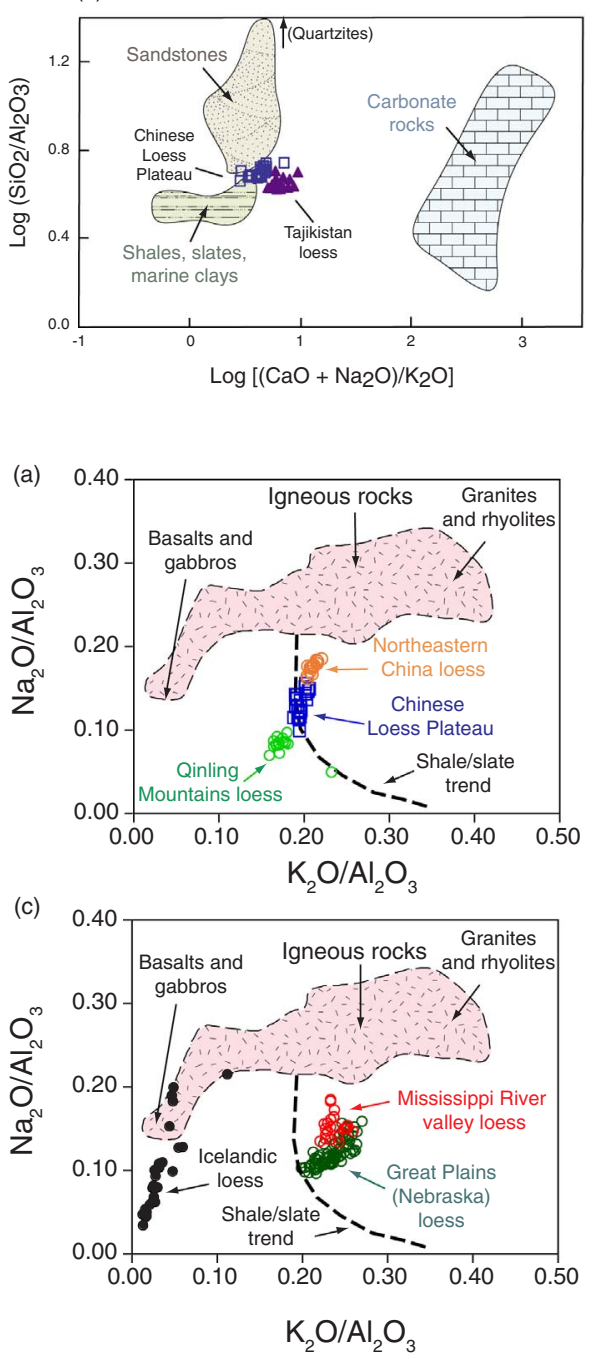

(c)

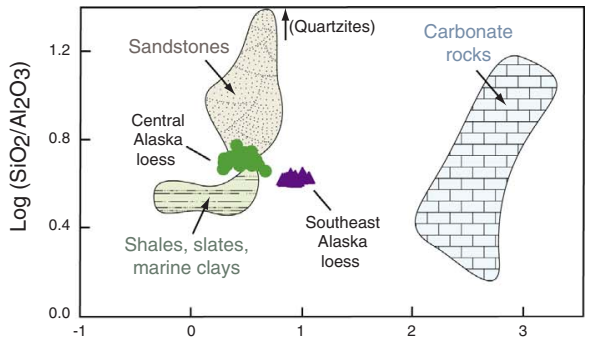

(d)

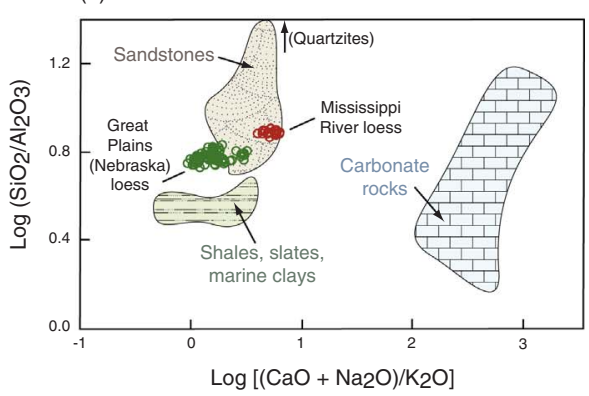

Fig. 16. Garrels and Mackenzie (1971) plot of major element ratios used for geochemical classification of sedimentary rocks and comparison of loess compositions with the fields defined by these rocks. Data sources: (a) Yakutia (Péwé and Journaux, 1983), Iceland (Jackson et al., 2005); (b) Chinese Loess Plateau (Gallet et al., 1996; Ding et al., 2001; Jahn et al., 2001); Tajikistan (Li et al., 2016); (c) central Alaska loess (Muhs et al., 2003, 2008c), southeastern Alaska loess (Muhs et al., 2013b); (d) Mississippi River valley loess (Pye and Johnson, 1988; Muhs et al., 2001); Great Plains loess (Muhs et al., 2008a).

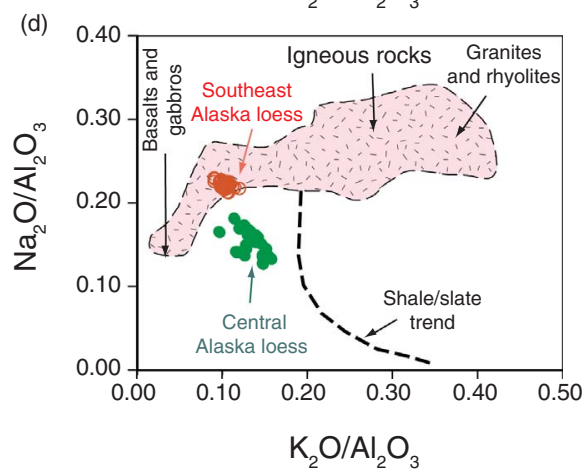

Fig. 17. Garrels and Mackenzie (1971) plot of major element ratios used for comparison of sedimentary rock compositions to field of igneous rock compositions and shale compositional trend line. Data sources are the same as in Fig. 16 except that in (a), data for northeastern Chinese loess are from Xie and Chi (2016) and data for loess of the Qinling Mountains are from Zhang et al. (2012).

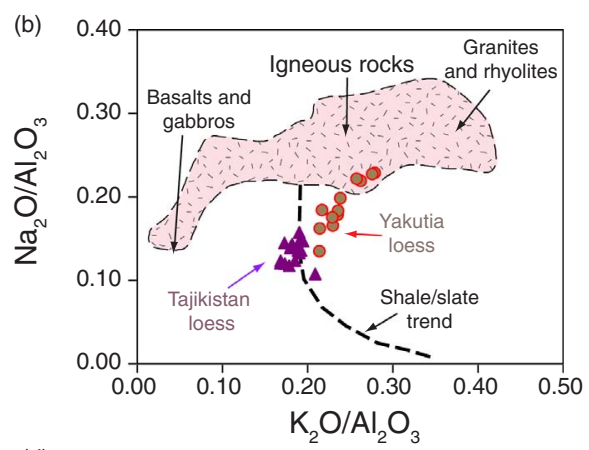

with regard to specific igneous rock contributions. The $\mathrm{K}_{2} \mathrm{O} / \mathrm{Al}_{2} \mathrm{O}_{3}$ versus $\mathrm{Na}_{2} \mathrm{O} / \mathrm{Al}_{2} \mathrm{O}_{3}$ plot yields less information about how loess composition compares with other sediments (and gives virtually no information about components derived from carbonate rocks) but gives detailed information about how loess composition compares to igneous rock sources and shales. Used together, the two plots are highly complementary and can provide much information about loess sources.

\section{Trace element geochemistry of loess and implications for origins}

4.1. Use of immobile trace elements (Sc-Th-La-Zr) to infer source rocks for loess

Major elements, of course, compose the bulk of loess bodies as they do for all geologic materials, and use of the Garrels and Mackenzie plots shows how they can provide useful information about source rocks. Nevertheless, the igneous petrology community has long recognized that trace elements are powerful tools for deciphering rock origins. Trace element geochemistry is becoming a more commonly used method for sediment provenance (see examples in Taylor and McLennan, 1985, 1995; Bhatia and Crook, 1986; McLennan, 1989; Gallet et al., 1996, 1998; Jahn et al., 2001; Sun, 2002a, 2002b; Zhang, 2004; Muhs and Budahn, 2006; Muhs et al., 2007a, 2007b, 2013b, 2016; Sun et al., 2007; Yang et al., 2007; Tao et al., 2014; Hu et al., 2017).

For provenance studies, the most useful elements to consider, on the basis of high ionic potential, are those that have little mobility in lowtemperature, near-surface environments. Such elements include $\mathrm{Cr}, \mathrm{Sc}$, $\mathrm{Ta}, \mathrm{Th}, \mathrm{Zr}$, Hf, As, and $\mathrm{Sb}$, as well as $\mathrm{Y}$ and the rare earth elements 
(REEs), La to Lu. Titanium, a minor element usually reported with major elements, is also useful in provenance studies. These minimally mobile elements are found in a wide variety of minerals (Mason and Moore, 1982). Common host minerals for Ti are ilmenite, pyroxene, hornblende and biotite. Two trace elements that substitute for $\mathrm{Fe}$ are $\mathrm{Cr}$ (enriched in pyroxenes as well as chromite), and Sc, found in pyroxenes, micas, amphiboles, titanite, and clay minerals. Micas, amphiboles, zircon, sphene and clay minerals can host Th and Ta. In addition, Ta can be found in magnetite or ilmenite. Zircon is the exclusive host of $\mathrm{Zr}$ and Hf. Both As and Sb most likely occur as substitutes for Fe in magnetite (Onishi and Sandell, 1955). The REE and Y are found in apatite, monazite, zircon, titanite, feldspars, and clay minerals.

One of the most useful suites of elements for provenance studies is Sc-Th-La, usually expressed graphically as a ternary diagram (Taylor and McLennan, 1985). Scandium is enriched in pyroxenes (thus it is higher in mafic rocks) whereas Th and La are enriched in granitic rocks. As a result, sediments derived from more mafic sources will tend to plot near the Sc pole and those derived from felsic sources will plot between the Th and La poles.

A simple example from some "natural" dust trap island landscapes illustrates the use of Sc-Th-La plots for identifying the provenance of suspected aeolian sediments. The California Channel Islands are situated off the Pacific Coast of North America and four of them are characterized wholly or largely by Miocene volcanic rocks, andesite or basalt. Soils on these islands have a mantle of silt-rich material $5-20 \mathrm{~cm}$ thick that contains minerals (quartz and mica) not found in the bedrock of the volcanic rocks. Muhs et al. (2007a, 2008b) hypothesized that these silt-rich mantles were essentially young loess derived from mainland California, accumulating when the typical northwesterly winds are reversed under "Santa Ana" conditions and westward transport of particles from the Mojave Desert on the mainland is possible. These investigators report Sc-Th-La data for the local bedrock (basalt and andesite), Mojave Desert dust (the most likely external, mainland source), and the clay and silt fractions of the loess mantles. On ternary
Sc-Th-La diagrams, average upper continental crust (UC) falls in the upper center of the triangle, reflecting the dominance of Th and La; average oceanic crust falls near the lower right corner, reflecting the dominance of Sc (Fig. 18). Results for the Channel Islands show that andesite, dominant on three of the islands, falls between the composition of oceanic crust (OC) and UC, and basalt, dominant on Santa Barbara Island, falls very close to OC. Mojave Desert dust, derived to a great extent from granitic terrains, shows variability, but its composition centers around UC values. Silts $(53-2 \mu \mathrm{m})$ from the loess mantles on all four islands fall within the range of Mojave Desert dust, close to UC values, and none overlap the values for andesite or basalt. These results suggest that the silt component of the loess mantles is externally derived, not from the island bedrock, but with the Mojave Desert on the mainland as a candidate source. Clays $(<2 \mu \mathrm{m})$ fall between the fields for local bedrock and Mojave Desert dust, suggesting that they may be derived in part from an external source and in part by in situ weathering of the local volcanic rocks.

With this simple example from California as an illustration, it is possible to expand the trace element provenance concept to incorporate a broader-scale exploration of rock sources for loess. Bhatia and Crook (1986) conducted a study of the provenance of Australian graywackes using these methods, tying the highly variable compositions to source rocks from different tectonic settings. These investigators used a suite of trace element plots to accomplish this, but two of the most effective are Sc-Th-La, as illustrated above, and Zr-Sc-Th. Using these two trace element arrays, Bhatia and Crook (1986) succeeded in identifying compositional variability for rocks derived from four tectonic settings, going from mafic to felsic: (1) oceanic island arc; (2) continental island arc; (3) active continental margin; and (4) passive continental margin (Fig. 19).

Loess from China falls virtually on top of the average upper continental crustal (UC) value on a Sc-Th-La diagram, indicating dominantly felsic sources (Fig. 19a). Loess from Tibet shows greater abundances of Th and La relative to Sc, indicating an even more felsic source

\section{Santa Cruz Island}

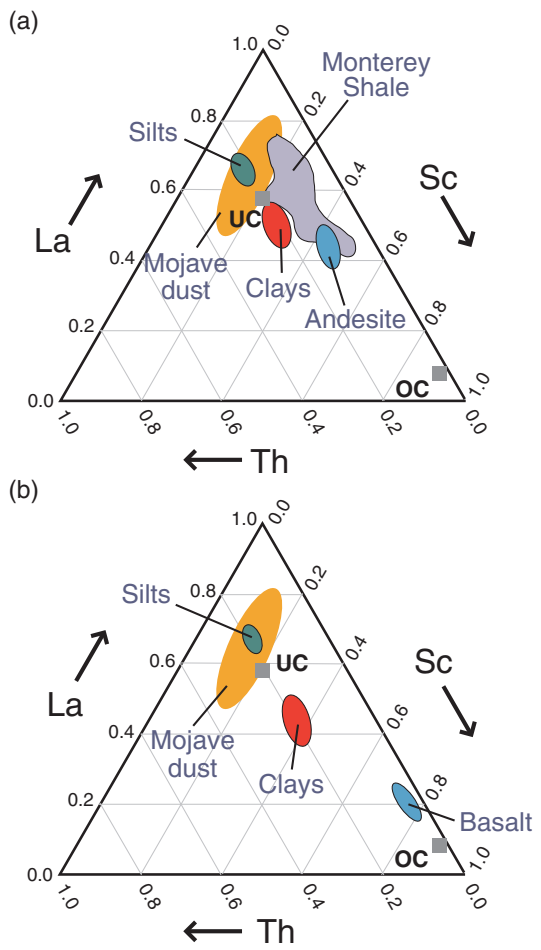

Santa Barbara Island

\section{San Clemente Island}

(c)

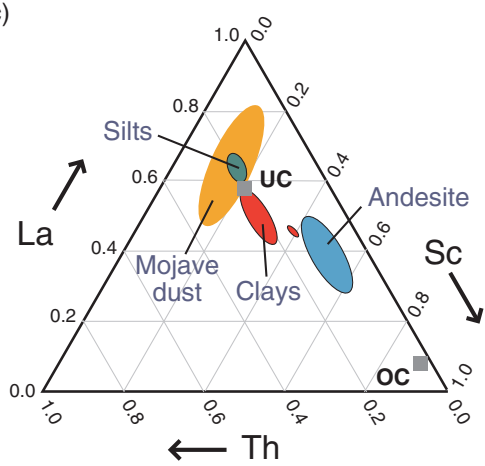

(d)

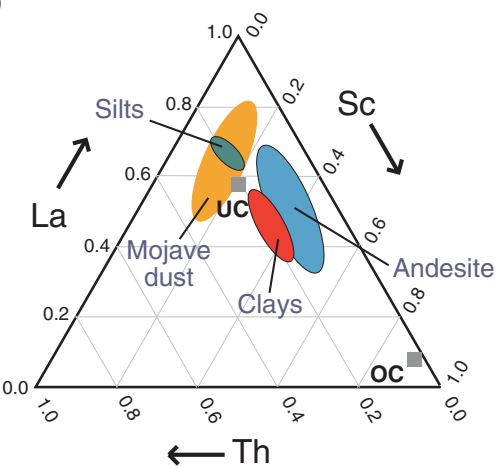

East Anacapa Island
Fig. 18. Ternary plots of island volcanic rocks, Mojave Desert dust, and loess mantles on the California Channel Islands (see Fig. 6 for general location), illustrating the use of Sc-Th-La diagrams to infer provenance. Channel Islands data are from Muhs et al. (2007a, 2008b); Mojave Desert dust data are from Reheis (2003) and Reheis et al. (2002). 
(a)

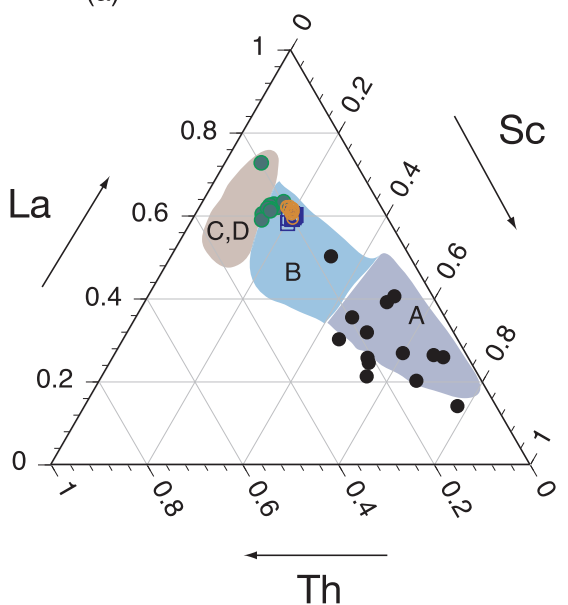

(b)

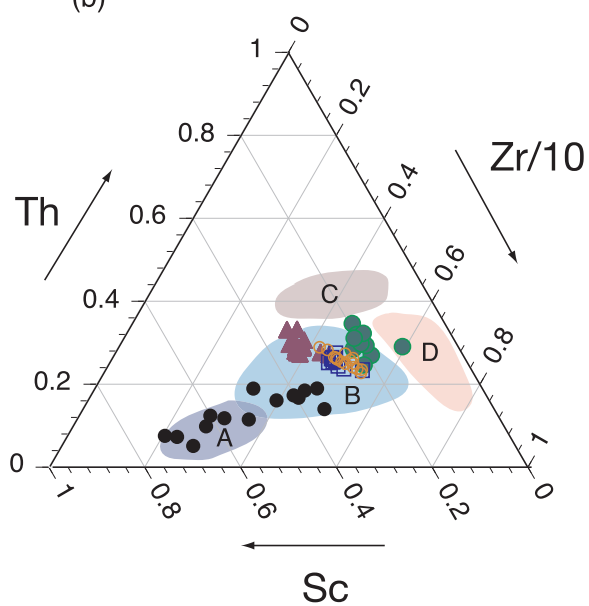

Fig. 19. Sc-Th-La and $\mathrm{Zr} / 10-\mathrm{Sc}-\mathrm{Th}$ plots for loesses from various parts of Asia and New Zealand. Also shown are fields of Sc-Th-La and $\mathrm{Zr} / 10$-Sc-Th compositions for potential source rocks from various tectonic settings (from Bhatia and Crook, 1986). Sources for Sc, Th, La, and Zr data: Tibetan loess (Sun et al., 2007); Tajikistan loess (Li et al., 2016); northeastern Chinese loess (Xie and Chi, 2016); Chinese Loess Plateau (Sun et al., 2007); New Zealand loess (Graham et al., 2001).

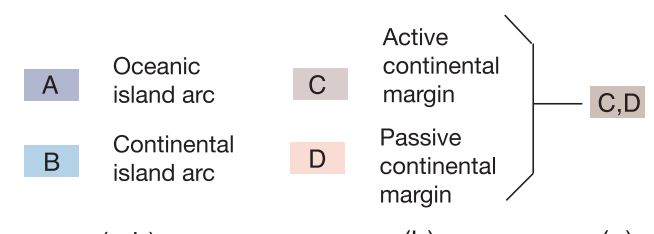

$(a, b)$ (b)

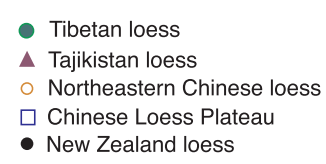

(a) or sources. To provide an extreme example of a differing composition (although not from Asia), loess from New Zealand plots within the compositional field of an "oceanic island arc" tectonic setting, which is consistent with the geology of these islands.

On a $\mathrm{Zr}$-Sc-Th diagram, there is general consistency with the interpretation of probable source rocks for Asian loess as seen with the ScTh-La data (Fig. 19b). Loesses from both regions of China have similar compositions, suggesting dominantly felsic source rocks, but Tibetan loess appears to have an even more felsic source than is the case for Chinese loess. In contrast, loess from Tajikistan has relatively higher amounts of Sc, indicating a more mafic source. As is the case with the Sc-Th-La diagram, loess from New Zealand indicates that this sediment has the most mafic sources of all.

In North America, all loess bodies, when plotted on a Sc-Th-La diagram, fall within the field of rocks defining the felsic "continental island arc" tectonic regime, similar to Asian loess, except for Great Plains (Kansas) loess, which falls into the "passive continental margin" field, at least for Zr-Sc-Th (Fig. 20a). Nevertheless, the fields are distinct for each of the loess bodies and it is possible to make some inferences about different source rocks that could have supplied the sediments. Lower Mississippi River valley loess (the $<20 \mu \mathrm{m}$ fraction, from Muhs et al. (2007b), which are the only data available) has a Sc-Th-La composition that is very similar to Chinese loess, and falls on the average UC composition. This is consistent with a Canadian Shield crystalline rock source, which is considered to be one of the more important glaciogenic supplies of loess in this valley (Grimley, 2000). The Great Plains loess samples from Kansas, reported by Taylor et al. (1983) have uncertain locations, but if they are similar to other localities adjacent to Nebraska described by Aleinikoff et al. (2008) and Muhs et al. (2008a), they reflect the very felsic White River Group volcaniclastic siltstone and Rocky Mountain crystalline rock sources described by those authors. Central Alaskan loess, on the other hand, shows contributions from somewhat more mafic sources, which could be some of the metasedimentary rocks of the Alaska Range, consistent with the interpretations of Muhs and Budahn (2006). Southeastern Alaskan loess has the most mafic signature of the three North American loesses considered here, but this loess body likely has received significant inputs from basaltic or andesitic source rocks in the Wrangell Mountains, plus metasedimentary rocks that had mafic protoliths (Muhs et al., 2013b).
On a Zr-Sc-Th plot, the same general interpretations can be made, and both Alaskan loess bodies again fall into the field defined by rocks with a "continental island arc" tectonic regime. However, lower Mississippi River valley loess has a composition intermediate between this field and that occupied by rocks with an even more felsic "active continental margin" regime (Fig. 20b).

\subsection{Use of rare earth elements to infer source rocks for loess}

The rare earth elements (REEs) have been used extensively in studies of igneous petrology to infer rock-forming processes and source magmas. However, by extension, the REE in sediments can yield important clues about what source rocks supplied the particles for those sediments. As is the case with Sc, Th, La, and Zr, discussed above, the REE have minimal mobility within near-surface environments. However, one advantage of the REE over certain other immobile trace elements for provenance studies is that they are found in a broad suite of minerals. Whereas $\mathrm{Zr}$ and $\mathrm{Hf}$ and $\mathrm{As}$ and $\mathrm{Sb}$ are found in heavy minerals (zircon and magnetite, respectively), the REE are found in both heavy and light minerals (amphiboles, micas, zircon, chlorite, clay minerals, apatite and even trace amounts in feldspars). Thus although $\mathrm{Zr}$, Hf, As and Sb may be biased somewhat towards indicators of heavy minerals that reflect nearby sources, the REE in aeolian sediments potentially can reflect both proximal and distal sources.

In using REE in sedimentary geochemistry, plots are typically made of the abundances of elements relative to chondritic meteorites, as is done in igneous petrology. Oceanic crust has little differentiation and generally shows a "flat" abundance curve from the lightest of the REE (La) to the heaviest (Lu). With increasing differentiation, the light REE (LREE) become enriched and the heavy REE (HREE) are depleted.

Europium has special significance in that it alone among the REE can exist stably in a divalent state and has an ionic radius that is close to $\mathrm{Sr}$. Thus, Eu can substitute for $\mathrm{Sr}$ in plagioclase. Igneous rocks derived from purely mantle sources, including mid-ocean ridge basalts and island-arc basalts, have not only a "flat" REE abundance curve, but abundances of Eu, relative to its lighter and heavier neighbors, Sm and $\mathrm{Gd}$, are similar. In felsic rocks of the upper continental crust, however, this is not the case. Not only do the LREE become relatively enriched and the HREE relatively depleted, Eu shows depletions relative to Sm 
(a)

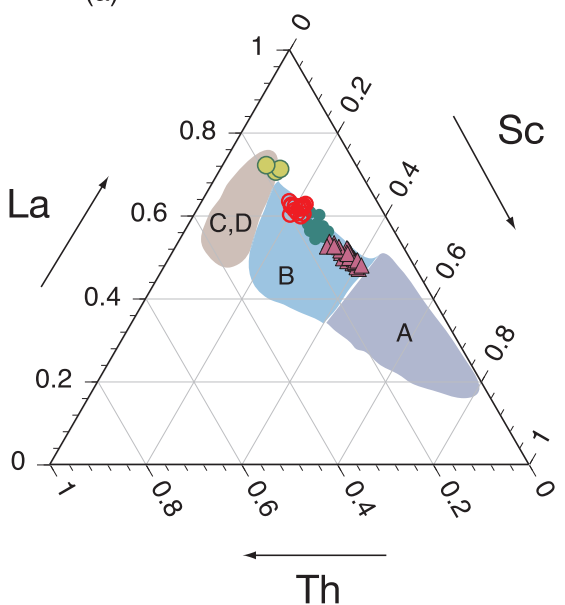

(b)

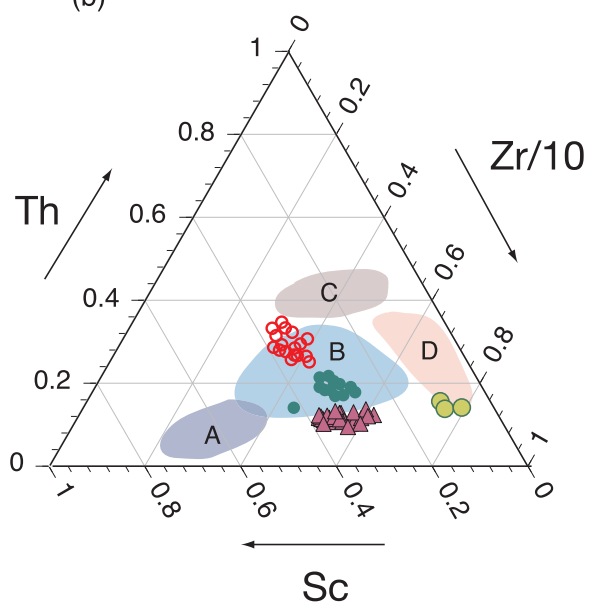

Fig. 20. Sc-Th-La and $\mathrm{Zr} / 10-\mathrm{Sc}$-Th plots for loesses from various parts of North America. Also shown are fields of ScTh-La and $\mathrm{Zr} / 10-\mathrm{Sc}-\mathrm{Th}$ compositions for potential source rocks from various tectonic settings (from Bhatia and Crook, 1986). Sources for Sc, Th, La, and Zr data: southeastern Alaskan loess (Muhs et al., 2013b); central Alaskan loess (Muhs and Budahn, 2006); Mississippi River valley loess (Muhs et al., 2007b); Great Plains (Kansas) loess (Taylor et al., 1983). Note that southeastern Alaskan loess is for the $<53 \mu \mathrm{m}$ fraction only and Mississippi River valley loess is for the $<20 \mu \mathrm{m}$ fraction only; data for central Alaskan loess and Great Plains (Kansas) loess are derived from bulk sediment analyses.

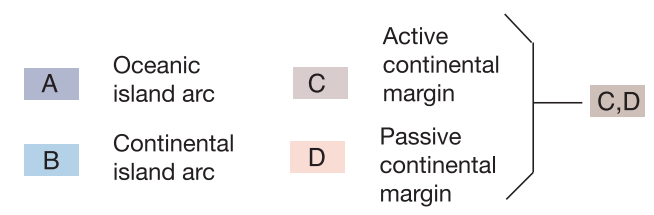

$(a, b)$ (b)

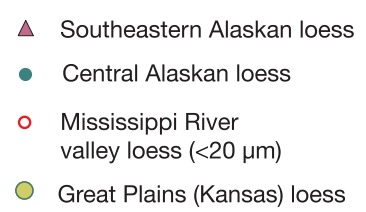

and Gd. The sign and degree of any Eu "anomaly" can be quantified by the $\mathrm{Eu} / \mathrm{Eu}^{*}$ value, where $\mathrm{Eu}$ is the chondrite-normalized $\mathrm{Eu}$ concentration $\left(\mathrm{Eu}_{\mathrm{N}}\right)$, and $\mathrm{Eu}^{*}$ is $\left(\mathrm{Sm}_{\mathrm{N}} \mathrm{x} \mathrm{Gd_{N }}\right)^{0.5}$ (where the subscript "N" refers to chondrite-normalized values for that element). Basalts that reflect a relatively pure mantle origin typically have no Eu anomaly and therefore have $\mathrm{Eu} / \mathrm{Eu}^{*}$ of 1.0 (see examples in Budahn and Schmitt, 1985). Values less than 1.0 indicate "negative" Eu anomalies; values greater than 1.0 indicate "positive" Eu anomalies. Lower crustal rocks typically have positive Eu anomalies, but upper crustal igneous rocks, as well as sedimentary rocks derived from them, typically have "negative" Eu anomalies, with $\mathrm{Eu} / \mathrm{Eu}^{*}$ values ranging from 0.6 to just under 1.0 (Taylor and McLennan, 1985, 1995; McLennan, 1989). Two other measures of REE composition reflect abundances of light and heavy REE. $\mathrm{La}_{N} / \mathrm{Yb}_{\mathrm{N}}$ is a measure of the overall enrichment of light REE, where high values reflect significant light REE enrichment. $\mathrm{Gd}_{N} /$ $\mathrm{Yb}_{\mathrm{N}}$ is a measure of heavy REE depletion, where high $\mathrm{Gd}_{\mathrm{N}} / \mathrm{Yb}_{\mathrm{N}}$ values indicate significant depletion of the heavy REE.

To illustrate the use of the REE in provenance studies, the example of loess mantles on the California Channel Islands is again referenced (Muhs et al., 2007a, 2008b). Basalt on Santa Barbara Island has the classic "flat" REE curve and shows no Eu anomaly (Fig. 21a). In contrast, both silt and clay fractions of the loess mantles above the basalt on this island show relative enrichment of the LREE, a negative Eu anomaly, and a flat HREE portion of the curve (Fig. 21b). On East Anacapa Island, the dominant rock type is andesite, and its more felsic character is seen with a slightly enriched LREE suite and a slight negative Eu anomaly (Fig. 21c). However, both the silts and the clays within the loess mantles on this island also show greater LREE enrichment and a more strongly negative Eu anomaly (Fig. 21d). Using the $\mathrm{La}_{\mathrm{N}} / \mathrm{Yb}_{\mathrm{N}}$ vs. Eu/Eu* measures described above, bivariate graphs show how REE plots can be reduced in an easy-to-interpret fashion with regard to provenance (Fig. 22). In this case, it is apparent that silts and clays in the loess mantles have closer REE compositions to Mojave Desert dust compared to the local islands' bedrock, consistent with the interpretations made from the Sc-Th-La plots discussed above (Fig. 18).

The REE have been applied to loess provenance studies in both Asia and North America. For the Chinese Loess Plateau, Liu (1988) identified a broad area to the northwest of the main loess body as the dominant source area for dust. Within this area, however, there are numerous mountain ranges, rimming structural depressions, flanked by alluvial fan deposits, and the basins are filled with dune sand and finer-grained sediments (Figs. 2, 4 and 5). Thus, while there is general agreement that some parts of the northwestern China region are the sources of dust, identification of specific dust-generating basins as sources for the Chinese Loess Plateau has been more controversial. Sun (2002a) reviewed the various hypotheses that had been proposed up to that point in time by a number of investigators. Sources as close as the Tengger Shamo Basin and as far away as the Tarim Basin have been suggested as possible sources for dust. Examination of satellite imagery shows that dust is entrained in many of these regions, so all are reasonable suggestions as sources based on modern observations (Fig. 23).

Sun (2002b) pointed out that loess deposits are found not only on the Loess Plateau itself, but also along the rims of the Tarim, Junggar, and Qaidam basins (Fig. 2). Reasoning that these loess deposits are likely derived from the respective basins to which they are adjacent, Sun (2002a) sampled loess from areas adjacent to these basins and isolated the $<20 \mu \mathrm{m}$ fraction, the finest-grained component that could conceivably be subject to long-range transport to the Loess Plateau. He then isolated the $<20 \mu \mathrm{m}$ fraction of samples from the Loess Plateau itself and did REE analyses of all $<20 \mu \mathrm{m}$ materials. Results, shown here on a $\mathrm{La}_{\mathrm{N}} / \mathrm{Yb}_{\mathrm{N}}$ vs. Eu/Eu* plot, indicate that Chinese Loess Plateau sediments that are $<20 \mu \mathrm{m}$ have a REE composition very close to that of the UC (Fig. 24a). Loess samples fractionated to $<20 \mu \mathrm{m}$ from the other regions have REE compositions that are not as close to that of the UC and are distinct from the composition of the Loess Plateau (Fig. 24a-c). Qaidam Basin-derived loess and Tarim Basin-derived loess have some overlap with the field defined by samples from the Loess Plateau, but numerous samples fall outside this field. Samples from the Junggar Basin have no overlap at all with those from the Loess Plateau. Sun (2002a) also provided other geochemical, mineralogical, and Srisotopic data that showed that loess bodies adjacent to these three basins are compositionally distinct and differ from the Chinese Loess Plateau. He concluded that more likely sources for the Loess Plateau are silts derived from alluvial fan deposits flanking the Qilian Shan in China, and the Gobi Altay and Hangayn Mountains in Mongolia (Fig. 2). In support of this concept, Sun (2002a) points out that surface winds strong enough to transport dust in the Tarim Basin are frequently from the northeast (Fig. 23a). While this explains the occurrence of loess on 

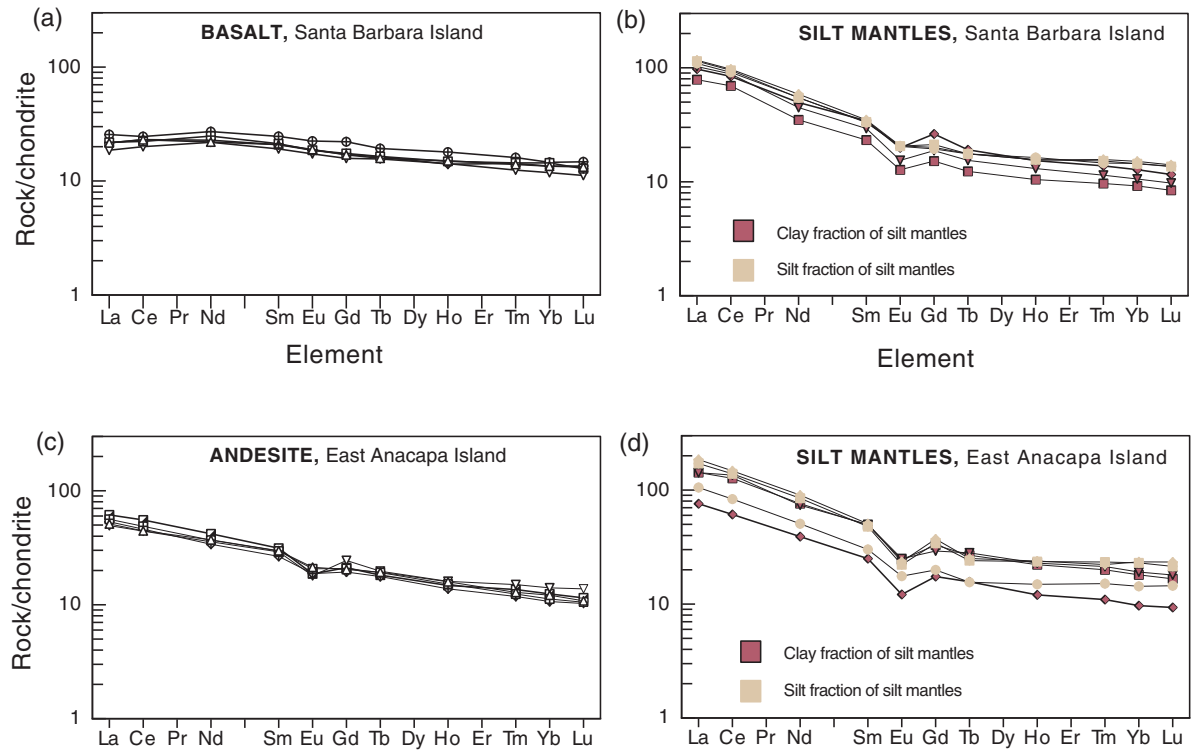

Fig. 21. Chondrite-normalized plots of rare earth element concentrations in local volcanic rocks and in the silt $(53-2 \mu \mathrm{m})$ and clay $(<2 \mu \mathrm{m})$ fractions of loess mantles on the California Channel Islands. Data from Muhs et al. (2008b). the north side of the Kunlun Shan, it is contrary to the idea that dust from the Tarim Basin is delivered to the Loess Plateau. On the other hand, modern, dust-transporting winds in the region around the Badain Jaran Shamo and Tengger Shamo are typically from the northwest, which could supply dust to the Loess Plateau (Fig. 23b). Hu and Yang (2016) note that alluvial fan sediments are delivered to the Badain Jaran and Tengger basins from the Altay Mountains, Gobi Altay, and the Qilian Shan (Fig. 2). From a number of studies, Hu and Yang (2016) compiled REE compositions of rocks from these mountains. Not surprisingly, given the diverse rock types in these mountain ranges, their results show a considerable range of variability in REE compositions (Fig. 24d). Nevertheless, a compilation of samples (mostly bulk analyses, but the $<20 \mu \mathrm{m}$ samples from Sun (2002a) are also shown) from the Loess Plateau fall squarely between the ranges of values for rocks in the Qilian Shan, the Altay Mountains, and the Mongolian Gobi (Fig. 24d). These results at least permit an interpretation that the Badain Jaran Shamo and Tengger Shamo, supplied with fine-grained sediments from these mountains, could be the immediate sources of dust for the Loess Plateau, in support of Sun's (2002a) proposal.

Other studies show that loess bodies elsewhere in China have distinct REE compositions, indicating separate sources for each. Although loess in the Harbin region of northeastern China (Fig. 2) has a REE composition that shows considerable overlap with the Chinese Loess Plateau, loess from the Qinling Mountains shows less overlap, and loess from the Xigaze area of Tibet (Fig. 2) shows no overlap at all (Fig. 25a-c). A worthwhile effort would be to inventory the REE composition of the smaller, more isolated loess bodies in southern China, well south of the Loess Plateau, to investigate whether their compositions are distinct.

Use of the REE has also been conducted in China to determine if sources for dust on the Loess Plateau have changed over time. Ding et al. (2001) investigated a thick section at Jiaxian, in the northern Chinese Loess Plateau (Fig. 2), that has, in its lower part, many meters of red clay deposits, thought to date from the Tertiary. These deposits are similar in character to those shown in the lower part of the section near Lanzhou (Fig. 3b). Results show that some of the Tertiary red clay deposits at Jiaxian have REE compositions that overlap those of Quaternary silts on the Loess Plateau, indicating the possibility of similar sources. However, many red clay samples have Eu/Eu* values that are significantly higher than those of Quaternary loess samples (Fig. 25d). The higher $\mathrm{Eu} / \mathrm{Eu}^{*}$ values are indicative of a more mafic source material, an intriguing notion that invites further study. (a) Santa Barbara Island

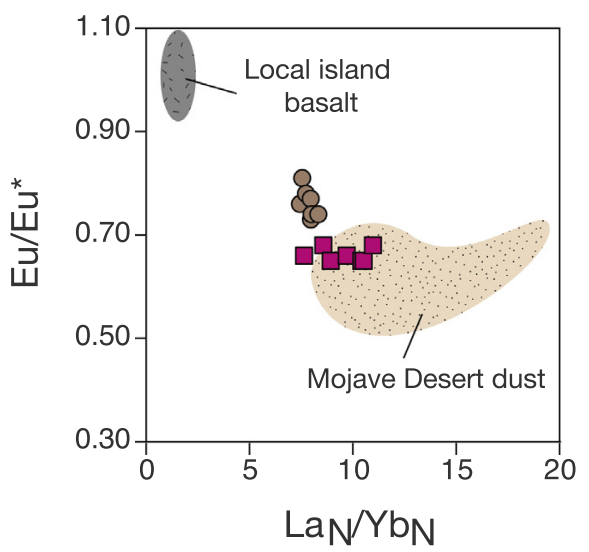

(b) East Anacapa Island

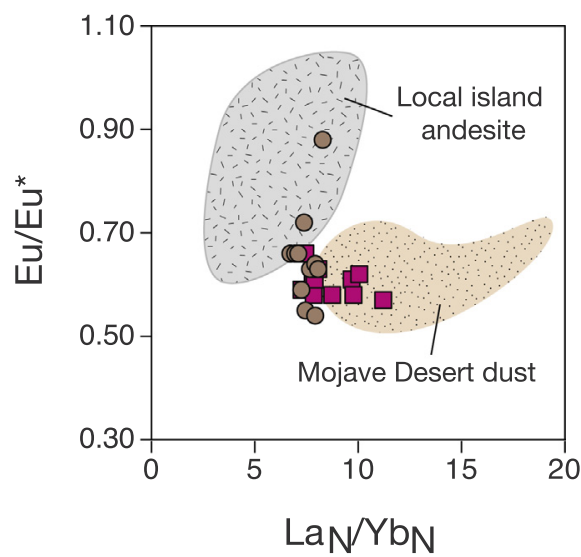

Fig. 22. Plots of $L a_{N} / \mathrm{Yb}_{N}$ vs. Eu/Eu ${ }^{*}$ for silt $(53-2 \mu \mathrm{m})$ and clay $(<2 \mu \mathrm{m})$ fractions of loess mantles on the California Channel Islands compared to local island volcanic rocks and Mojave Desert dust. Channel Islands data are from Muhs et al. (2008b); Mojave Desert dust data are from Reheis (2003) and Reheis et al. (2002).

- Silt fraction $(53-2 \mu \mathrm{m})$

- Clay fraction $(<2 \mu \mathrm{m})$ 


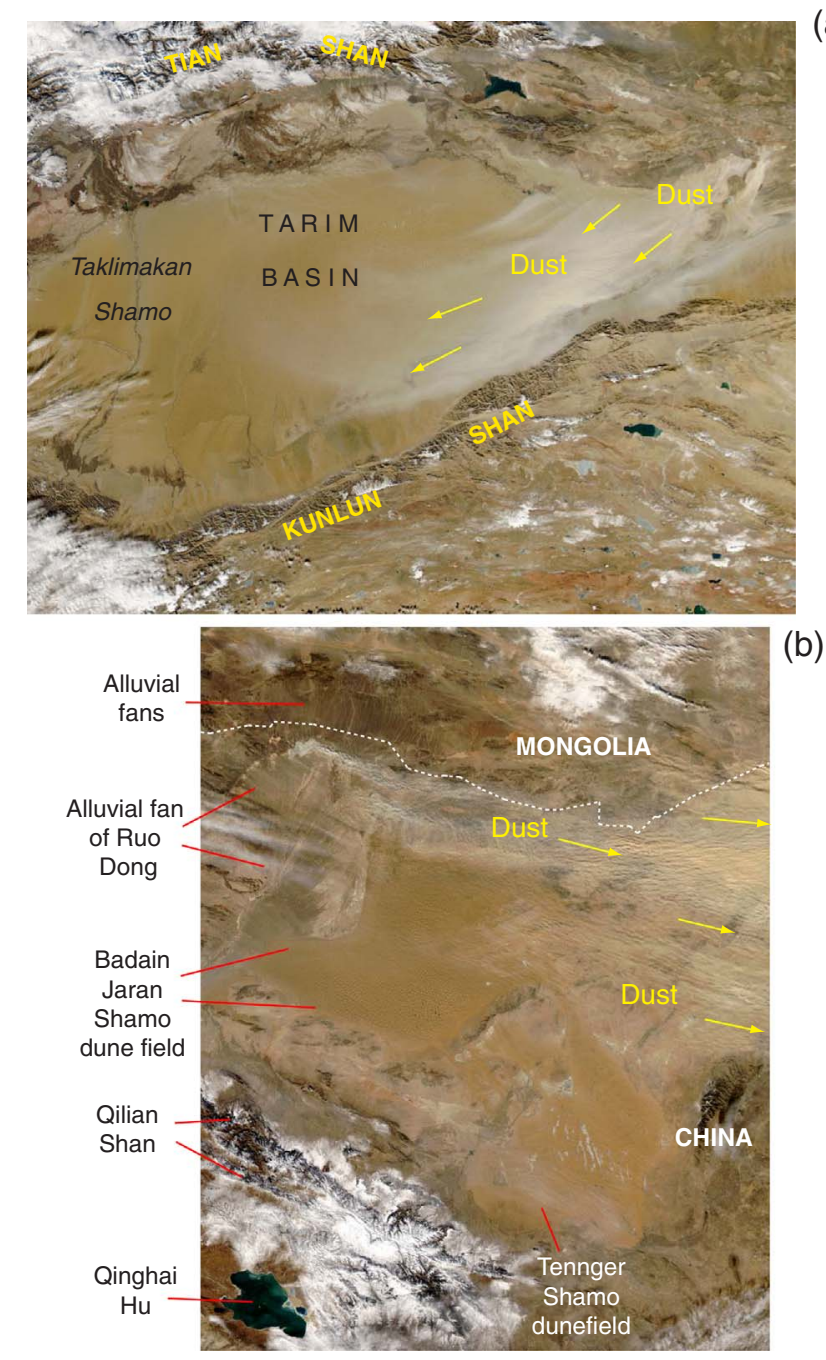

Fig. 23. MODIS images of arid basins in China showing modern dust sources and directions of movement. (a) Tarim Basin (Taklimakan Shamo) and surrounding glaciated mountains (Tian Shan and Kunlun Shan), with dust moving from northeast to southwest towards the northern flank of the Kunlun Shan. Image acquired on 3 December 2005 from the Aqua satellite. (b) MODIS image of southern Mongolia and northern China showing dust sources such as the Badain Jaran Shamo and Tennger Shamo (sandy deserts) and alluvial fans, and dust plumes moving from west-northwest to east-southeast towards the Chinese Loess Plateau. Image acquired from the Aqua satellite on 27 November 2012. Images in both (a) and (b) courtesy of Jeff Schmaltz, MODIS Rapid Response Team, NASA-Goddard Space Flight Center.

In North America, studies of REE compositions of loess for inferences about provenance have not been as extensive as in China, but some data are available. The fine-grained $(<20 \mu \mathrm{m})$ fraction of lower Mississippi River valley loess (from localities in Louisiana, Mississippi, and Tennessee shown in Fig. 7) was investigated as a possible longrange-transported aeolian source for soils on Caribbean islands (Muhs et al., 2007b). Thus, although bulk analyses are not presently available, these data allow at least some preliminary comparisons with REE compositions of Chinese loess. The two loess bodies show considerable overlap and both have values close to the UC (Fig. 26a). Loess from the lower Mississippi River is derived from outwash of the Laurentide Ice Sheet. The southern lobes of this glacier that reached the Mississippi River drainage (Fig. 7) eroded terrains rich in Precambrian crystalline rocks (granitic rocks and gneisses), Paleozoic shales and carbonate rocks, and Cretaceous shales (Fig. 8). Such a broad mix of upper continental crustal material not surprisingly results in a REE composition for loess that is very close to that of the UC. Data on the REE composition of loess from the Great Plains region (Kansas; see Fig. 7) shown in
Fig. 26a are from Taylor et al. (1983) and as discussed earlier, specific localities where these samples were collected are unknown. Nevertheless, if they are derived from the same sources as loess in adjacent Nebraska, then as with the Sc-Th-La composition, the REE composition of this loess is consistent with a combination of felsic, non-glacial, volcaniclastic siltstone and silts from felsic Precambrian crystalline rocks of the Rocky Mountains of Colorado and Wyoming.

Loess from central Alaska (Fig. 10), studied by Muhs and Budahn (2006) also has a REE composition similar to that of the Chinese Loess Plateau and the UC (Fig. 26b). This composition is consistent with other data presented earlier indicating that this loess is derived primarily from felsic sources in granitic mountain ranges, as well as metasedimentary rocks. In contrast, loess from the Matanuska Valley of southcentral Alaska (Fig. 10) has significantly higher $\mathrm{Eu} / \mathrm{Eu}^{*}$ and significantly lower $\mathrm{La}_{\mathrm{N}} / \mathrm{Yb}_{\mathrm{N}}$, indicating more mafic sources (Fig. 26c). Muhs et al. (2016) concluded, based on comparisons with alluvial silts, that the main source of loess in this region is the Matanuska River, which is fed by glaciogenic silts derived from the Talkeetna and Chugach Mountains. Although both mountain ranges host granitic rocks, they also contain larger amounts of metasedimentary rocks with mafic protoliths, which explains this composition.

An even more dramatic example of a mafic composition is seen in Holocene loess from southeastern Alaska, near the dominantly volcanic Wrangell-St. Elias Mountains (Fig. 10). These mountains, which still host large glaciers (Figs. 10 and 11) are composed of a wide variety of rocks, but include mafic volcanic rocks, plus older metasedimentary rocks with mafic protoliths. Furthermore, loess in this area also receives contributions from the Chugach Mountains, a range that contains abundant mafic metasedimentary rocks as well (Muhs et al., 2013b). Thus, loess in this part of Alaska has the highest $\mathrm{Eu} / \mathrm{Eu}^{*}$ of any aeolian silts yet studied in Alaska, as well as relatively low $\mathrm{La}_{\mathrm{N}} / \mathrm{Yb}_{\mathrm{N}}$ (Fig. 26d). One inference that can be drawn from these examples is that in a lithologically diverse region such as Alaska, loess compositions are expected to vary considerably from location to location, but REE concentrations, when expressed as $\mathrm{Eu} / \mathrm{Eu}^{*}$ vs. $\mathrm{La}_{\mathrm{N}} / \mathrm{Yb}_{\mathrm{N}}$, seem to be capable of allowing direct ties to the most likely immediate-source rivers and the ultimate-source rocks that supply the particles.

\section{Chemical weathering in loess-derived paleosols and implications for paleoclimate}

\subsection{Soil formation versus loess sedimentation and chemical weathering as a function of climate}

One characteristic of loess sequences worldwide, making them particularly valuable as archives of Quaternary climate change, is that in addition to accumulations of aeolian silt (which yield direct records of atmospheric circulation), loess units are separated stratigraphically by buried soils, or paleosols. Soils form when rates of sedimentation diminish to the point where pedogenic processes can become dominant and soil profile differentiation, expressed as horizons, can commence. In certain regions, such as Europe and the glaciated portion of North America, loess supplies at present are largely absent and soil formation has been ongoing since the end of the last glacial period. Thus, periods of loess deposition mark glacial periods and paleosols mark interglacial or interstadial periods. This has led to the concept that loess-paleosol sequences are the closest terrestrial equivalent of the deep-sea oxygen isotope record, because in some regions, loess production "turns on" during glacial periods and "turns off" during interglacial periods. Indeed, even by the 1980s, there were attempts at correlation of loess records in Europe (Wintle et al., 1984) and China (Kukla et al., 1988) with the deep-sea oxygen isotope record.

While the "turn on/turn off" loess/paleosol sedimentation concept has some validity, at least in broad terms, for some parts of Europe and North America (where large ice sheets provided the silts for loess), it has complications in other regions. In Alaska, glacial supplies still exist, 

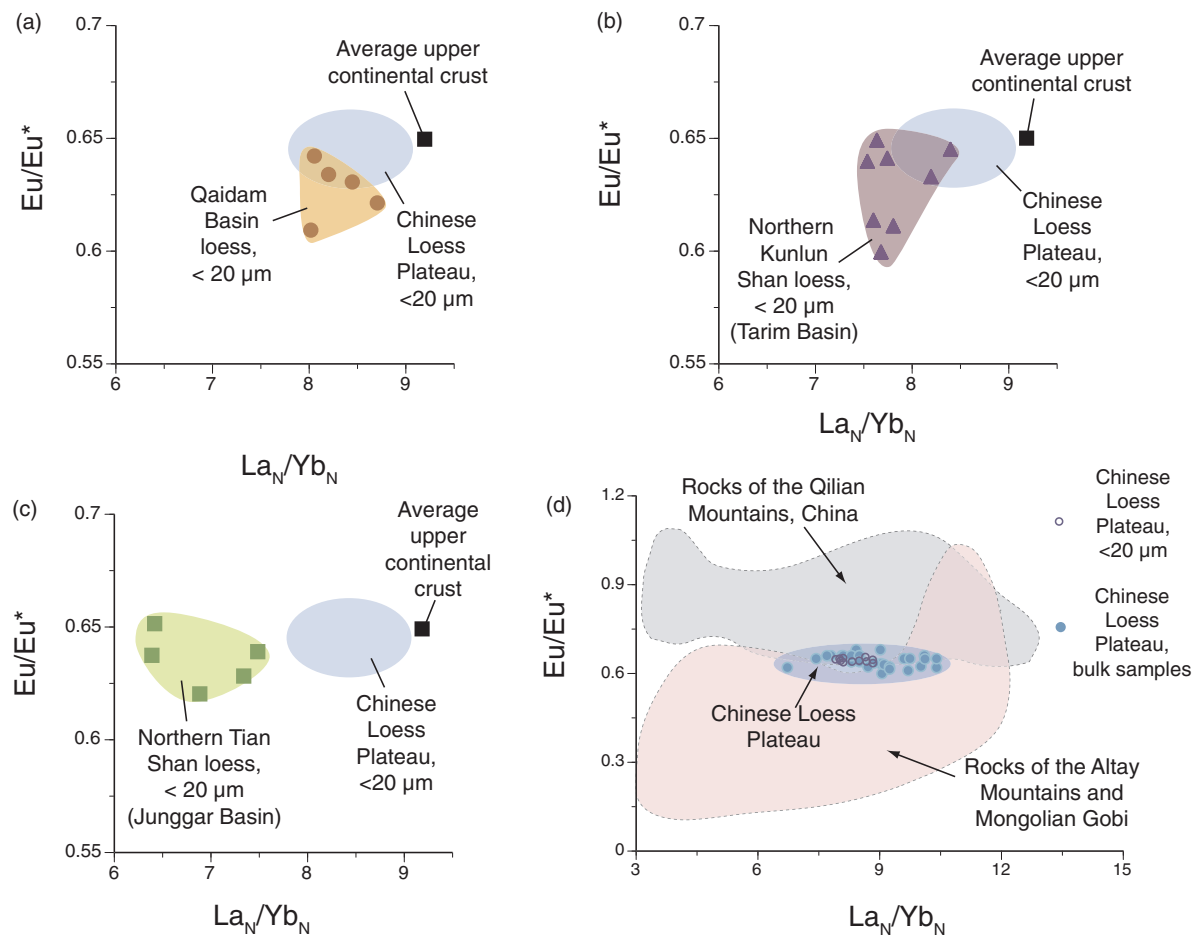

Fig. 24. (a-c): Plots of $\mathrm{La}_{\mathrm{N}} / \mathrm{Yb}_{\mathrm{N}}$ vs. Eu/Eu for the $<20 \mu \mathrm{m}$ fraction of loess deposits in various parts of China compared to the same size fraction for deposits of the Chinese Loess Plateau; data from Sun (2002a, 2002b). Also shown for comparison is the composition of the average upper continential crust (from Taylor and McLennan, 1985). (d) Plot of $\mathrm{La}_{\mathrm{N}} / \mathrm{Yb}_{\mathrm{N}}$ vs. $\mathrm{Eu} / \mathrm{Eu}^{*}$ for loess of the Chinese Loess Plateau (both bulk samples and $<20 \mu \mathrm{m}$ fraction) compared to range of compositions of rocks from the Qilian Shan (see Figs. 2 and 23b for location) and the Altay Mountains and Mongolian Gobi (see Fig. 2 for location). Chinese Loess Plateau $\mathrm{La}_{\mathrm{N}} / \mathrm{Yb}_{\mathrm{N}}$ and $\mathrm{Eu} / \mathrm{Eu}^{*}$ data are from Gallet et al. (1996), Ding et al. (2001), Jahn et al. (2001), Sun (2002a), and Sun et al. (2007); ranges of $\mathrm{La}_{\mathrm{N}} / \mathrm{Yb}_{\mathrm{N}}$ and $\mathrm{Eu} / \mathrm{Eu}^{*}$ values for the Qilian Shan, Altay Mountains, and Mongolian Gobi are from compilation by Hu and Yang (2016) and sources therein. with dust transport and loess accumulation still taking place (Fig. 11). Where loess accumulation is rapid, soil formation processes cannot keep up. In contrast, well downwind of zones of loess accumulation, soil formation is an ongoing process. Between these two extremes are zones where loess accumulation and soil formation are both active processes: soil formation occurs, but small increments of dust are added to developing soils (Muhs et al., 2004). In China, there is little question that dust is still being transported at the present time (see Figs. 4 and 23) and modern dust sources, pathways, and end points have been well studied (Derbyshire et al., 1998; Sun et al., 2001). Thus, the view that dust transport and loess accretion in China are limited to glacial periods is clearly oversimplified. What is more appropriate as a concept for Chinese loess-paleosol sequences in China (and by extension for Alaska) was nicely articulated by Verosub et al. (1993) when they stated that loess accretion and pedogenesis in China are essentially competing processes. During glacial periods, loess accretion is dominant, but
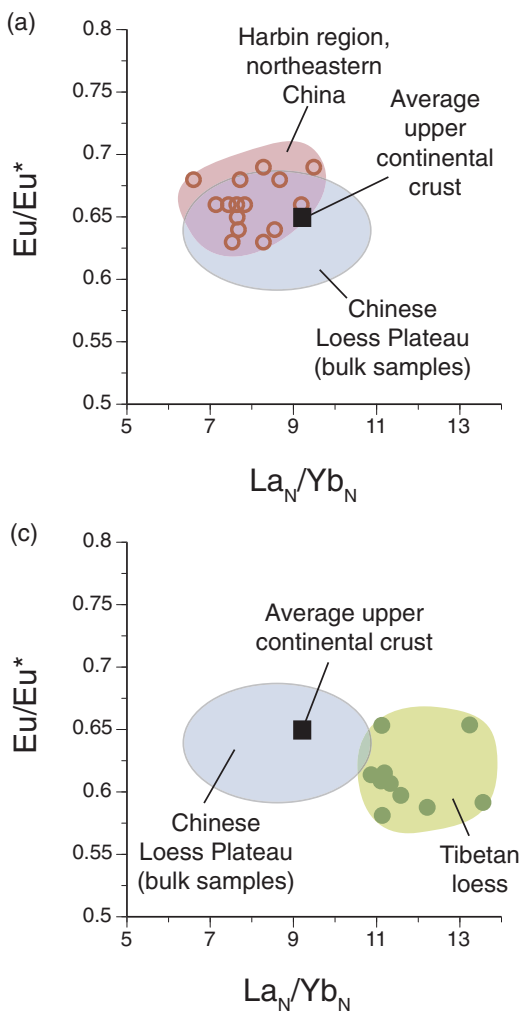
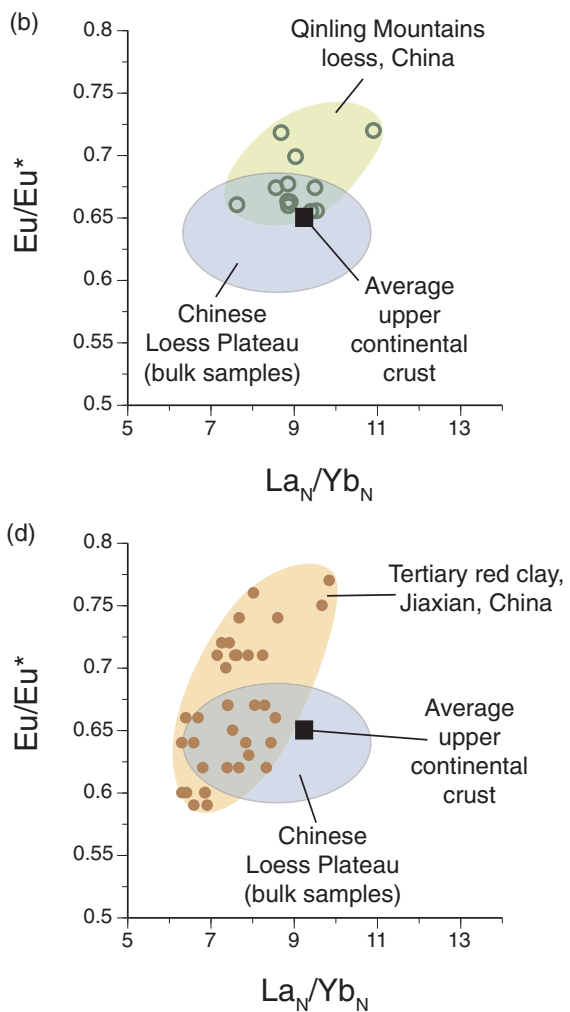

Fig. 25. (a-c): Plots of $\mathrm{La}_{\mathrm{N}} / \mathrm{Yb}_{\mathrm{N}}$ vs. Eu/Eu* in bulk loess (i.e., all size fractions) for deposits from the Harbin region of northeastern China, the Qinling Mountains, and Tibet (locations shown in Fig. 2) compared to the Chinese Loess Plateau. Sources of Chinese Loess Plateau data are the same as in Fig. 24; data for other localities are from Sun et al. (2007) [Tibet], Zhang et al. (2012) [Qinling Mountains], and Xie and Chi (2016) [Harbin area, northeastern China]. (d) Plot of $\mathrm{La}_{\mathrm{N}} / \mathrm{Yb}_{\mathrm{N}}$ vs. Eu/Eu* in Tertiary "red clay" deposits from Jiaxian, China (see Fig. 2 for location; data source is Ding et al. (2001)) compared to bulk loess from the Chinese Loess Plateau (sources as above). 


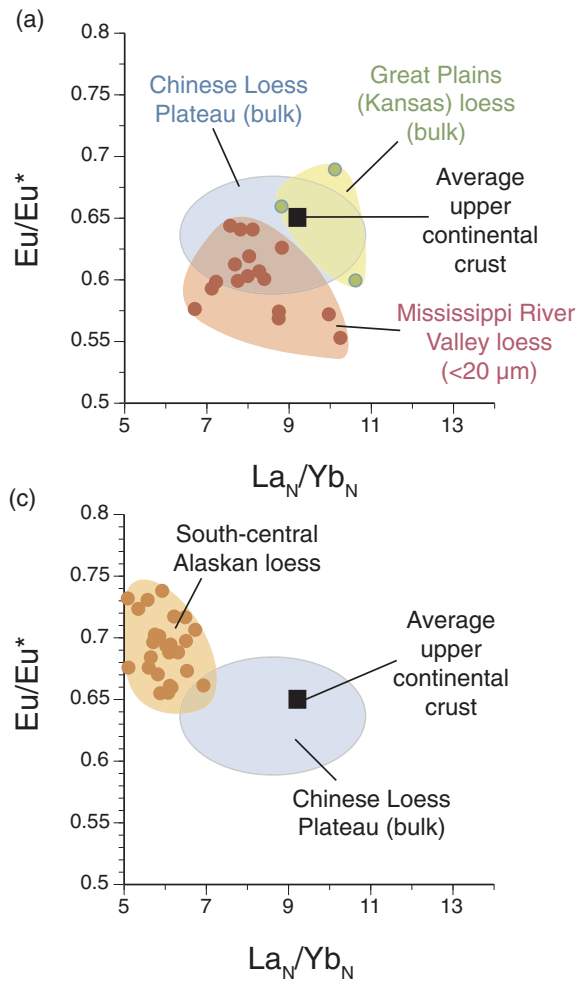

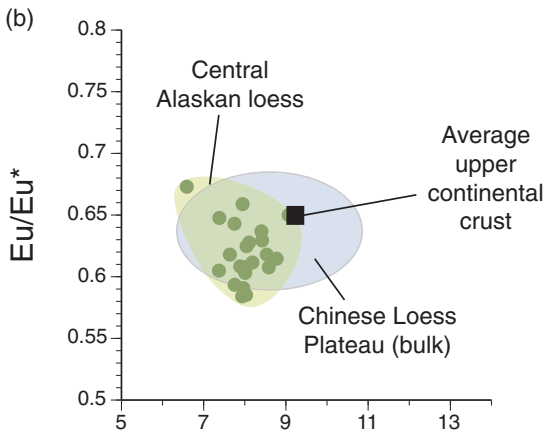

Fig. 26. Plots of $\mathrm{La}_{\mathrm{N}} / \mathrm{Yb}_{\mathrm{N}}$ vs. Eu/Eu" in loess from various parts of North America compared to the Chinese Loess Plateau. North American data from Taylor et al. (1983) [Great Plains (Kansas) loess]; Muhs et al. (2007b) [Mississippi River valley loess]; Muhs and Budahn (2006) [central Alaska loess]; Muhs et al. (2016) [south-central Alaska loess]; and Muhs et al. (2013b) [southeastern Alaska loess]; Chinese Loess Plateau data from same sources as in Fig. 24.

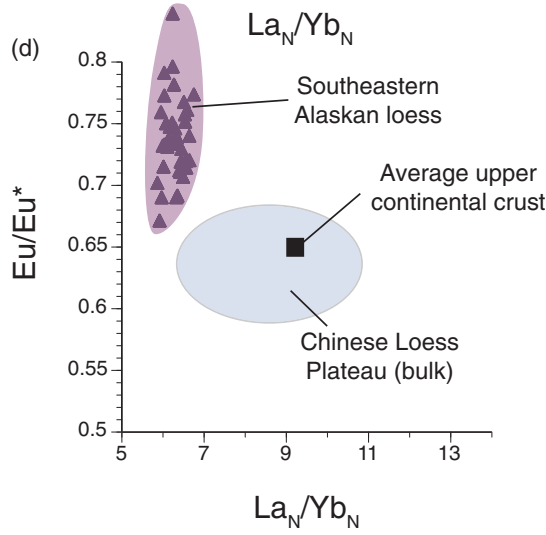

syndepositional weathering and incipient soil formation can still take place. During interglacial periods, pedogenesis becomes dominant, but loess accretion, albeit at a lower rate, can continue. Even in areas of North America where the "turn-on/turn-off" glaciogenic loess deposition concept has some validity, minimally developed paleosols, consisting of pale, thin incipient A horizons, can be found within last-glacial-aged Peoria Loess, although sedimentation rates overall were quite high (Ruhe, 1983). Recognition of the complex interplay of loess sedimentation and pedogenesis is crucial to valid paleoclimatic interpretations of loess-paleosol sequences in general and the geochemistry of paleosols in particular. With these qualifications in mind, it is possible, however, to explore what the geologic record of loess-derived paleosols presents using geochemistry and what it implies for paleoclimatic interpretations.

Use of paleosols for paleoclimatic interpretations requires an understanding of the five soil-forming factors, as articulated by Jenny (1941) and explored in modern pedology texts by Birkeland (1999) and Schaetzl and Thompson (2015). These factors are climate, organisms (biota), relief (topographic position), parent material, and time. Over the past several decades, there have been a number of attempts to isolate the particular importance of each factor by keeping the other factors constant (or as much as the natural world will allow, anyway) and developing soil chronosequences, soil toposequences, and so on. In studying loess-paleosol sequences for paleoclimatic interpretations, the importance of both soil chronosequences (in order to estimate the duration of pedogenesis) and soil climosequences (in order to understand how climate affects rates and directions of pedogenesis) on modern landscapes become the most critical.

There are few locations where one can reliably develop a soil climosequence to understand how the geochemistry of soils developed in loess might change as a function of climate, keeping all the other factors of soil formation constant. However, one such area that has been explored for this purpose is the Mississippi River valley (Fig. 7), where the final episodes of loess deposition during the last glacial period occurred at approximately the same time (thus controlling the "time" factor), site locations can be chosen for similar topographic positions (the "relief" factor), the underlying loess is compositionally similar, all derived from the Mississippi River valley (the "parent material" factor), and forested vegetation is typical along the entire length of the river valley (the "organisms" factor). What is left is a mix of climate variables, where precipitation and mean annual temperatures are higher in the southern part of the valley (Louisiana and Mississippi) and lower in the northern part of the valley (Iowa and Illinois). Because chemical weathering of minerals requires water and proceeds at higher rates with higher temperatures, loss of soluble elements due to weathering should be greatest in the southern part of the valley and least in the northern part of the valley. Muhs et al. (2001) tested this hypothesis in a soil climosequence study of 22 pedons developed in last-glacial Peoria Loess over the length of the valley, covering a precipitation gradient from $\sim 1550 \mathrm{~mm} / \mathrm{yr}$ in the south to $\sim 780 \mathrm{~mm} / \mathrm{yr}$ in the north. Minerals in Peoria Loess along the Mississippi River valley include quartz, plagioclase, K-feldspar, mica, amphiboles, calcite, dolomite, and clay minerals such as smectite, mica, kaolinite, and possibly chlorite (Frye et al., 1962, 1968; Snowden and Priddy, 1968; Grimley et al., 2003). With the exception of quartz, all of these minerals can potentially experience chemical weathering given favorable climatic conditions and enough time (Birkeland, 1999). Using various lines of evidence, Bettis et al. (2003) estimate that Peoria Loess deposition in the Mississippi River valley probably ended around $14,000-13,000 \mathrm{cal}$ yr B.P. Although it is assumed that precipitation amounts were different from present at times during the past $\sim 14,000 \mathrm{yr}$, it is likely that the present precipitation gradient existed during all or most of the time of pedogenesis.

Results from the soil climosequence study indicate that many of the primary minerals have experienced losses, with greatest losses in the southern portion of the transect (Fig. 27). Abundances of soluble major elements $\left(\mathrm{CaO}, \mathrm{MgO}, \mathrm{Na}_{2} \mathrm{O}, \mathrm{K}_{2} \mathrm{O}\right.$ ) were compared to abundances of relatively immobile $\mathrm{TiO}_{2}$ and $\mathrm{ZrO}_{2}$ and summed as profile averages. Results for major element depletions are similar whether normalized to $\mathrm{TiO}_{2}$ or $\mathrm{ZrO}_{2}$. All soluble major element losses indicate logarithmic or linear decreases as a function of mean annual precipitation. Coefficients of determination are high, with $\sim 75 \%$ of the variability explained by mean annual precipitation. Loss of $\mathrm{CaO}$ likely represents depletion of calcite, dolomite, and possibly some Ca-plagioclase; MgO loss is likely also from depletion of these minerals (Fig. 27a and b). Depletion of Na- 
(a) Calcite, dolomite, and Ca-plagioclase:

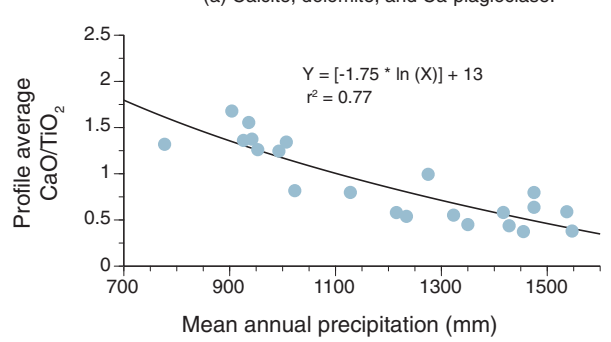

(c) Na-plagioclase:

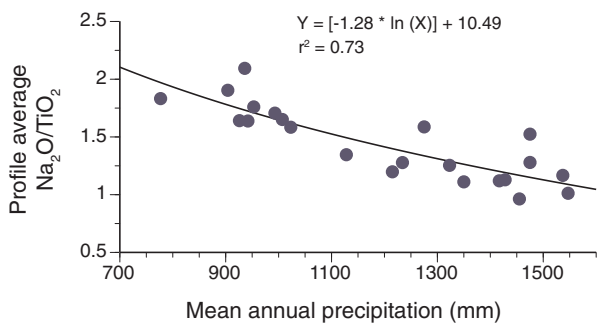

(b) Dolomite and calcite:

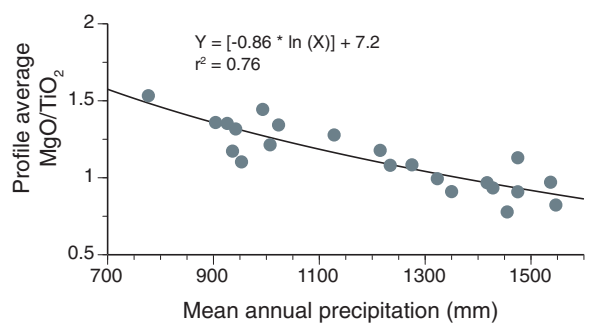

Fig. 27. Plots of soluble major elements (and the minerals they represent) in Peoria Loess-derived modern soils relative to immobile $\mathrm{TiO}_{2}$ in a soil climosequence along a moisture gradient in the Mississippi River valley (see Fig. 7 for localities). Note that element ratios are weighted profile averages, using soil horizon thicknesses as weights. Precipitation data are from the National Climatic Data Center, Asheville, North Carolina; geochemical data are from Muhs et al. (2001). plagioclase (and possibly some hornblende) is inferred from lower $\mathrm{Na}_{2} \mathrm{O} / \mathrm{TiO}_{2}$ values (Fig. 27c), while decreases in $\mathrm{K}_{2} \mathrm{O} / \mathrm{TiO}_{2}$ are likely due to losses of mica and possibly some K-feldspar depletion (Fig. 27d). Trace elements that follow these major elements (normalized to $\mathrm{Zr}$ ) also decrease as a function of precipitation. Strontium, which substitutes for $\mathrm{Ca}$ in Ca-bearing minerals, shows a logarithmic increase in loss with higher precipitation $\left(r^{2}=0.86\right)$. Rubidium and Ba, which substitute for $\mathrm{K}$ in K-feldspars and micas, also show greater losses with greater precipitation, although the degree of explanation $\left(r^{2}=0.51\right.$ and 0.43 , respectively) is not as high. This observation is important, as there has been a tendency for investigators in loess research to use $\mathrm{Rb} / \mathrm{Sr}$ as a weathering index, with the assumption that $\mathrm{Rb}$ is more resistant to loss by solution than $\mathrm{Sr}$. This practice is not recommended, as the results indicate that $\mathrm{Rb}$ is also subject to loss.

\subsection{Chemical weathering in loess-derived paleosols in Asia}

One of the most dramatic Quaternary loess sections that has received detailed study for its geochemistry is in the southern Chinese Loess Plateau at Lingtai (Fig. 2). At this locality, Yang et al. (2006) describe a section more than $\sim 100 \mathrm{~m}$ thick, extending back in time to $\sim 1.5 \mathrm{Ma}$, and containing 20 paleosols. These investigators did major element analyses of the entire section and compared mobile elements to relatively immobile elements such as $\mathrm{Al}_{2} \mathrm{O}_{3}$ and $\mathrm{TiO}_{2}$. Here, their data are replotted as individual mobile element abundances relative to $\mathrm{TiO}_{2}$ with a view to examining how they represent specific minerals.

An overall pattern that emerges is variability of soluble element concentrations (normalized to $\mathrm{TiO}_{2}$ ) at glacial-interglacial timescales (Fig. 28). Although, as discussed earlier, loess deposition and soil formation are competing processes on the Chinese Loess Plateau, soils show more depletion of soluble major elements compared to subjacent loess deposits that serve as their parent material. For example, the modern soil, S0, is developed in loess of last-glacial age, L1. This soil shows depletion of carbonate minerals, calcite and dolomite, as shown by lower $\mathrm{CaO} / \mathrm{TiO}_{2}$ values compared to $\mathrm{L} 1$ loess. Loss of Na-plagioclase (and possibly hornblende) in this soil is also inferred from lower $\mathrm{Na}_{2} \mathrm{O}$ / $\mathrm{TiO}_{2}$ values compared to the underlying loess. Somewhat more modest losses of K-bearing minerals (K-feldspar and mica) are apparent in the plot of $\mathrm{K}_{2} \mathrm{O} / \mathrm{TiO}_{2}$. The last-interglacial soil (S1) and the penultimate interglacial soil (S2) show even more dramatic losses of calcite, dolomite, and Na-plagioclase than the modern S0 soil, due either to a longer period of pedogenesis, a paleoclimate more favorable to mineral dissolution (i.e., warmer and wetter, with an enhanced summer monsoon) or more likely both of these factors.

Yang et al. (2006) developed a chemical weathering index for this section, based on the sum of $\mathrm{CaO}$ and $\mathrm{MgO}$ (representing carbonate minerals) and $\mathrm{Na}_{2} \mathrm{O}$ (representing plagioclase) relative to $\mathrm{TiO}_{2}$ (representing resistant Ti-bearing heavy minerals). They report that this chemical weathering index $\left(\mathrm{CaO}+\mathrm{MgO}+\mathrm{Na}_{2} \mathrm{O}\right) / \mathrm{TiO}_{2}$, shows variability at two different timescales at Lingtai. Variability is apparent on a glacial-interglacial timescale, and this trend is parallel to the plots for individual major elements, as discussed above. However, there is also variability of their weathering index at a longer timescale, also seen in the individual element plots for $\mathrm{CaO} / \mathrm{TiO}_{2}, \mathrm{MgO} / \mathrm{TiO}_{2}$, and $\mathrm{Na}_{2} \mathrm{O} / \mathrm{TiO}_{2}$. Yang et al. (2006) note that the alternations of high index values, or minimal evidence of weathering (during periods of loess deposition) and low index values, or greater weathering (during periods of soil formation) fall within a relatively narrow range of variability during the earliest part of the record, from $\sim 1.5 \mathrm{Ma}$ to $\sim 0.65 \mathrm{Ma}$. A regression line they computed (and recomputed identically here) for variability of their chemical weathering index as a function of depth is essentially vertical during the time interval from 1.5 Ma to $0.65 \mathrm{Ma}$ (Fig. 28). In contrast, from the midPleistocene $(\sim 0.65 \mathrm{Ma})$ to the present, the chemical weathering index shows increasing values, during both glacial and interglacial periods. A regression line computed by Yang et al. (2006) (and recomputed here) for this later period shows a distinct slope, indicating diminished chemical weathering, regardless of climatic conditions, towards the present. Yang et al. (2006) point out that a decrease in chemical weathering of both loess and paleosols since the mid-Pleistocene must be due to decreased chemical weathering in loess source areas. Diminished chemical weathering can be caused by both colder and drier climatic conditions. Yang et al. (2006) note that both of these climatic conditions could have occurred in China since the mid-Pleistocene. Colder conditions since the mid-Pleistocene could be due to the shift from a $41 \mathrm{ka}$ to a 100 ka glacial-interglacial orbital forcing cycle and generally greater global ice volume and colder conditions in the latter part of the Pleistocene (Ding et al., 1995; Liu and Ding, 1998). Drier conditions since the mid-Pleistocene could have resulted from tectonic uplift of the Tibetan Plateau (Li, 1991; Sun and Liu, 2000), which would have brought about a more arid climate in the loess source areas. 


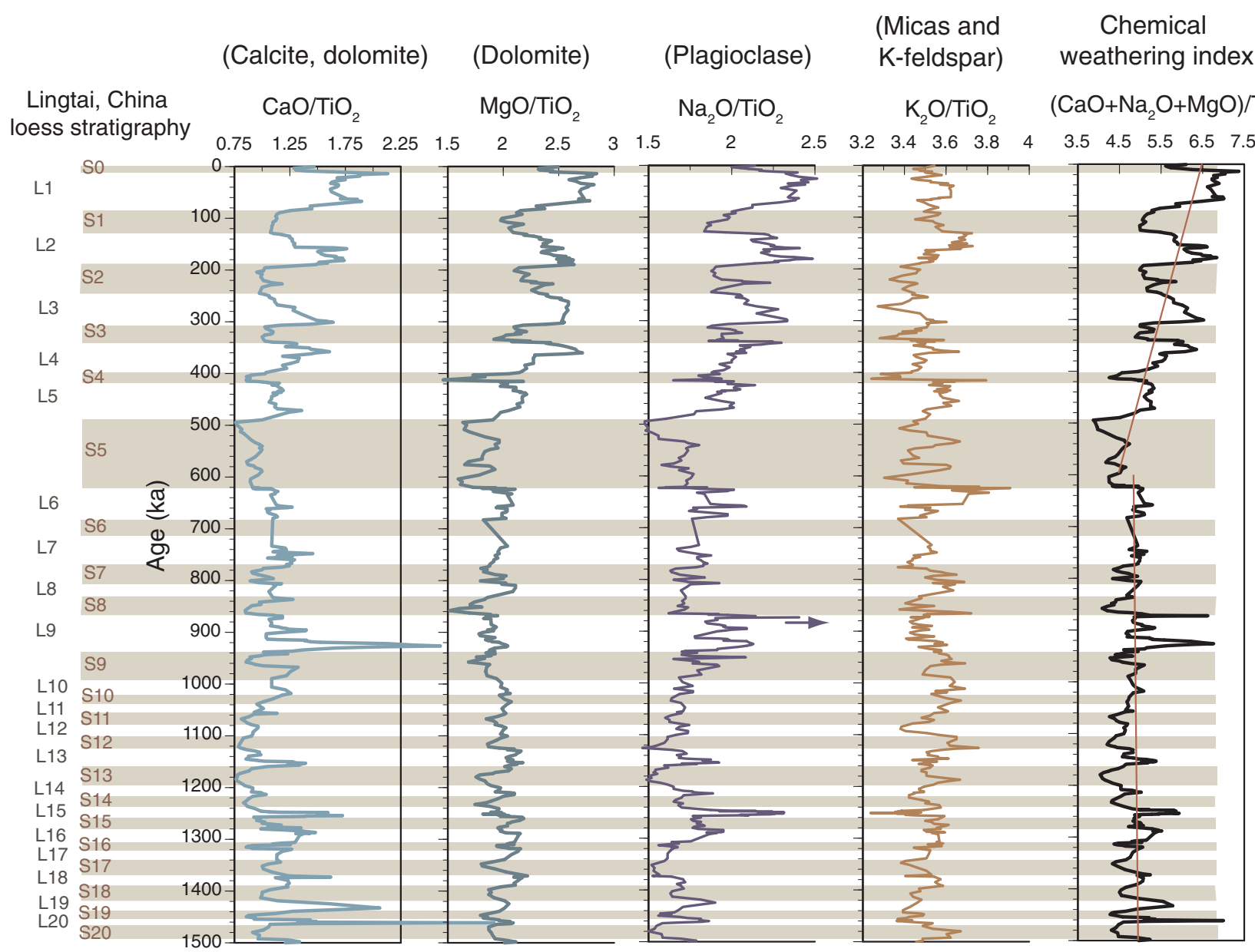

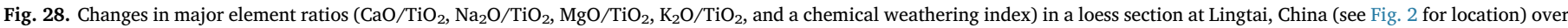

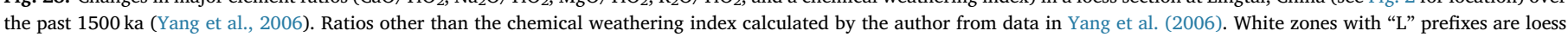
units (glacials and stadials); shaded zones with "S" prefixes are paleosols (interglacials and interstadials). The time scale is taken from Ding et al. (2002a).

It is interesting to consider if additional Asian loess-paleosol sequences exhibit similar geochemical records of both glacial-interglacial cycles and longer-term trends of diminished weathering in source areas. Thick loess sections are also found in Central Asia (Dodonov, 2007) and some of the best are found in Tajikistan, such as that shown in Fig. 4 of Dodonov (2007) at Chashmanigar (see location on Fig. 5). As discussed earlier, loess in Tajikistan has much higher abundances of carbonate minerals (see Fig. 16b), which is consistent with carbonate mineral abundance data reported for loess in this region by Dodonov et al. (2006). This compositional difference is seen in the stratigraphic section at Chashmanigar, also studied by Yang et al. (2006). Here, CaO/ $\mathrm{TiO}_{2}$ values are much higher than those seen in the section at Lingtai (Figs. 28 and 29). Ding et al. (2002b) consider that the sandy deserts to the west of Tajikistan, the Karakum and Kyzylkum (see map of these dune fields in Maman et al. (2011)), are the most likely sources of dust that has accumulated as loess, and these regions are the likely sources of the higher carbonate mineral content.

The loess section at Chashmanigar shows the same significant alternations of mineral depletion in the modern soil and paleosols as in the loess section at Lingtai (Fig. 29). One difference, however, is that some of the interglacial paleosols (S1, S2, S5) show spikes of high carbonate content, based on the $\mathrm{CaO} / \mathrm{TiO}_{2}$ plot. A drier climate in the past could conceivably explain this difference, but this seems unlikely, as Lingtai currently receives $\sim 600 \mathrm{~mm} / \mathrm{yr}$ precipitation and Chashmanigar receives $\sim 842 \mathrm{~mm} / \mathrm{yr}$ (Yang et al., 2006). Thus, unless the precipitation gradient between the two localities was drastically different in the past, it seems more likely that southern Tajikistan simply accumulates a much more carbonate-rich dust from its sources compared to the Chinese Loess Plateau. Additionally, the $\mathrm{K}_{2} \mathrm{O} / \mathrm{TiO}_{2}$ plot at Chashmanigar does not always show depletions in the paleosols compared to the loess units with which they are associated. Examples of this include the S4-L5, S5-L6, S8-L9 paleosol-loess couplets (Fig. 29). These observations may suggest that there has been little or no weathering of K-bearing minerals and that the section is exhibiting the natural range of variability in K-bearing minerals, unrelated to weathering. Apart from these differences, plots of $\mathrm{MgO} / \mathrm{TiO}_{2}$ and $\mathrm{Na}_{2} \mathrm{O} / \mathrm{TiO}_{2}$ show depletions in paleosols compared to underlying loess units. Using the same chemical weathering index, $\left(\mathrm{CaO}+\mathrm{MgO}+\mathrm{Na}_{2} \mathrm{O}\right) / \mathrm{TiO}_{2}$, as at Lingtai, Yang et al. (2006) point out that there is also a change in overall major element geochemistry in the mid-Pleistocene. Based on fitted regression lines, at Chashmanigar the change in regime seems to be at $\sim 0.85 \mathrm{Ma}$, earlier than that observed at Lingtai. Despite this difference, Yang et al. (2006) attribute the mid-Pleistocene change in composition at Chashmanigar to be due to the same causes as those observed at Lingtai.

\subsection{Chemical weathering in loess-derived paleosols in North America}

One significant difference between the loess-paleosol records of Asia and those of North America is that the latter records contain only a fraction of the time period of their Asian counterparts. Apart from Alaska, where the record may go back to $\sim 3.0 \mathrm{Ma}$ (Westgate et al., 1990), in midcontinental North America, loess records older than the penultimate glacial period (equivalent to Chinese loess unit L2) rarely 


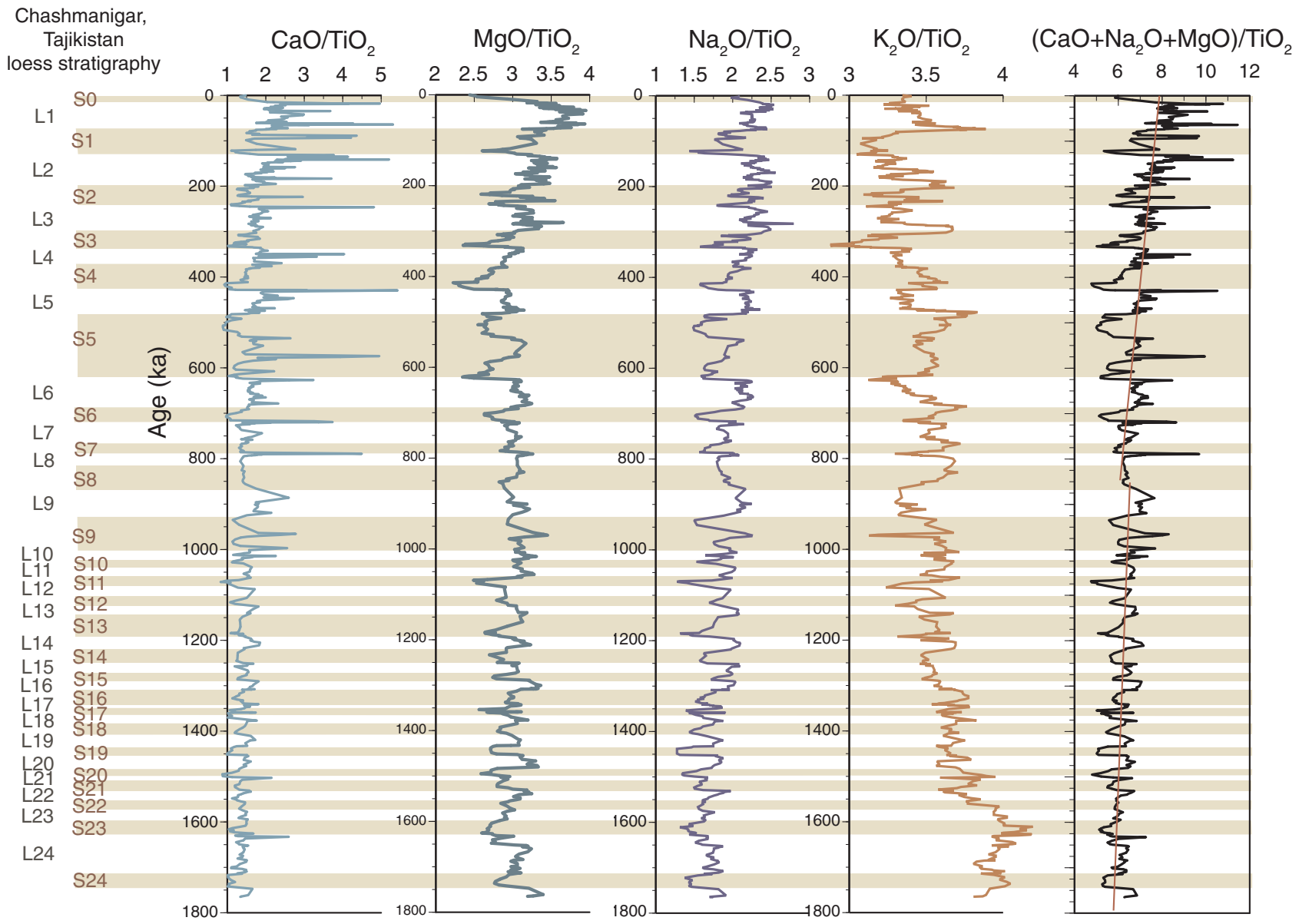

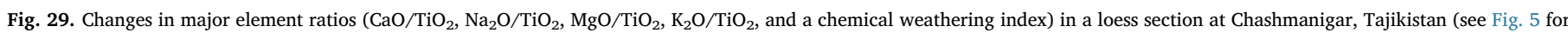

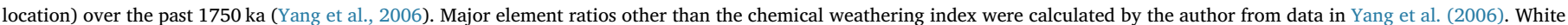

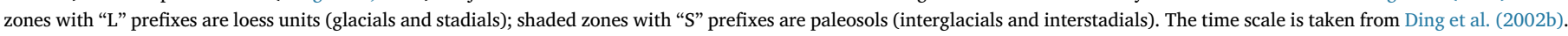

are exposed or even apparent from drilling. In the few places where older loess units are exposed (e.g., Fig. 9b), they are typically altered throughout due to pedogenesis. Furthermore, unlike Asia, two of the youngest loess units in midcontinental North America (Loveland Loess, equivalent to Chinese L2 and Peoria Loess, equivalent to Chinese L1LL1) are much thicker than older units. Indeed, glaciogenic Peoria Loess (in Iowa) has a thickness of up to $\sim 40 \mathrm{~m}$ (Muhs and Bettis, 2000; Muhs et al., 2013a) and nonglaciogenic Peoria Loess (in Nebraska) has a thickness of up to $\sim 45 \mathrm{~m}$ (Mason, 2001; Muhs et al., 2008a). In contrast, the underlying Roxana Loess (as it is called in the Mississippi River valley; approximately equivalent to Chinese L1LL2) and its equivalent the Gilman Canyon Formation (as it is called in the Great Plains) is much thinner. In fact, Roxana Loess and the Farmdale Soil (approximately equivalent to Chinese L1SS1) developed in it sometimes are so thin that they are misidentified as a buried A horizon of the underlying Sangamon Soil (Fig. 9a). Deposits older than Loveland Loess are extremely rare and are very thin where they exist at all. The reasons for both the lack of older loess records and the extraordinary thickness of last-glacial-aged loess in midcontinental North America have been discussed by Mason et al. (2007), who offer two explanations: (1) much greater dust production during the last glacial period and (2) widespread erosional removal of the older loess record, to a far greater extent than that seen on other continents.

In the Mississippi River valley, a more complete loess section that has been described is a locality near Thebes, Illinois (Fig. 7). The loess at this locality has been studied previously by Grimley et al. (2003). Here, more than $6 \mathrm{~m}$ of Peoria Loess are exposed, underlain by Roxana Loess, in which the Farmdale Soil has developed, in turn underlain by
Loveland Loess, in which the Sangamon Soil has developed (Fig. 30). Below Loveland Loess is a unit called Crowleys Ridge Loess and the Yarmouth Soil has developed in this oldest loess. Loss of calcite and dolomite in the modern soil developed in Peoria Loess is apparent based on low $\mathrm{CaO} / \mathrm{TiO}_{2}$ values. The modern soil has also experienced some loss of plagioclase, based on lower $\mathrm{Na}_{2} \mathrm{O} / \mathrm{TiO}_{2}$ values in the uppermost horizons but apparently little or no loss of mica or K-feldspar, based on $\mathrm{K}_{2} \mathrm{O} / \mathrm{TiO}_{2}$ values. Apatite loss is apparent in the lower horizons of the modern soil, based on lower $\mathrm{P}_{2} \mathrm{O}_{5} / \mathrm{TiO}_{2}$ values (in upper horizons, it is higher due to biocycling; see Runge et al., 1974). Alteration of the same minerals is apparent in the Farmdale Soil developed in Roxana Loess, with also some mica or K-feldspar loss, based on somewhat lower $\mathrm{K}_{2} \mathrm{O}$ / $\mathrm{TiO}_{2}$ values. The Sangamon Soil, developed in Loveland Loess, displays significant mineral alteration, with lower values for $\mathrm{CaO} / \mathrm{TiO}_{2},(\mathrm{CaO}$ $\left.+\mathrm{MgO}+\mathrm{Na}_{2} \mathrm{O}\right) / \mathrm{TiO}_{2}, \mathrm{Na}_{2} \mathrm{O} / \mathrm{TiO}_{2}, \mathrm{~K}_{2} \mathrm{O} / \mathrm{TiO}_{2}$, and $\mathrm{P}_{2} \mathrm{O}_{5} / \mathrm{TiO}_{2}$ compared to the modern soil (Fig. 30). An even greater degree of weathering is apparent in the oldest paleosol, the Yarmouth Soil, developed in Crowleys Ridge Loess.

The greater degree of chemical weathering exhibited in the Sangamon Soil compared to the modern soil is consistent with morphological data that show better profile development (thicker soil profiles, higher clay content, better ped structures, redder hues) that are typical of the Sangamon Soil throughout much of the North American midcontinent (Thorp et al., 1951; Simonson, 1954; Ruhe, 1969, 1974; Ruhe et al., 1974; Hall and Anderson, 2000; Grimley et al., 2003; Markewich et al., 2011). More intense weathering of the Sangamon Soil in comparison to the modern soil raises the question of whether climate or time was a factor, as either could bring about the observed 


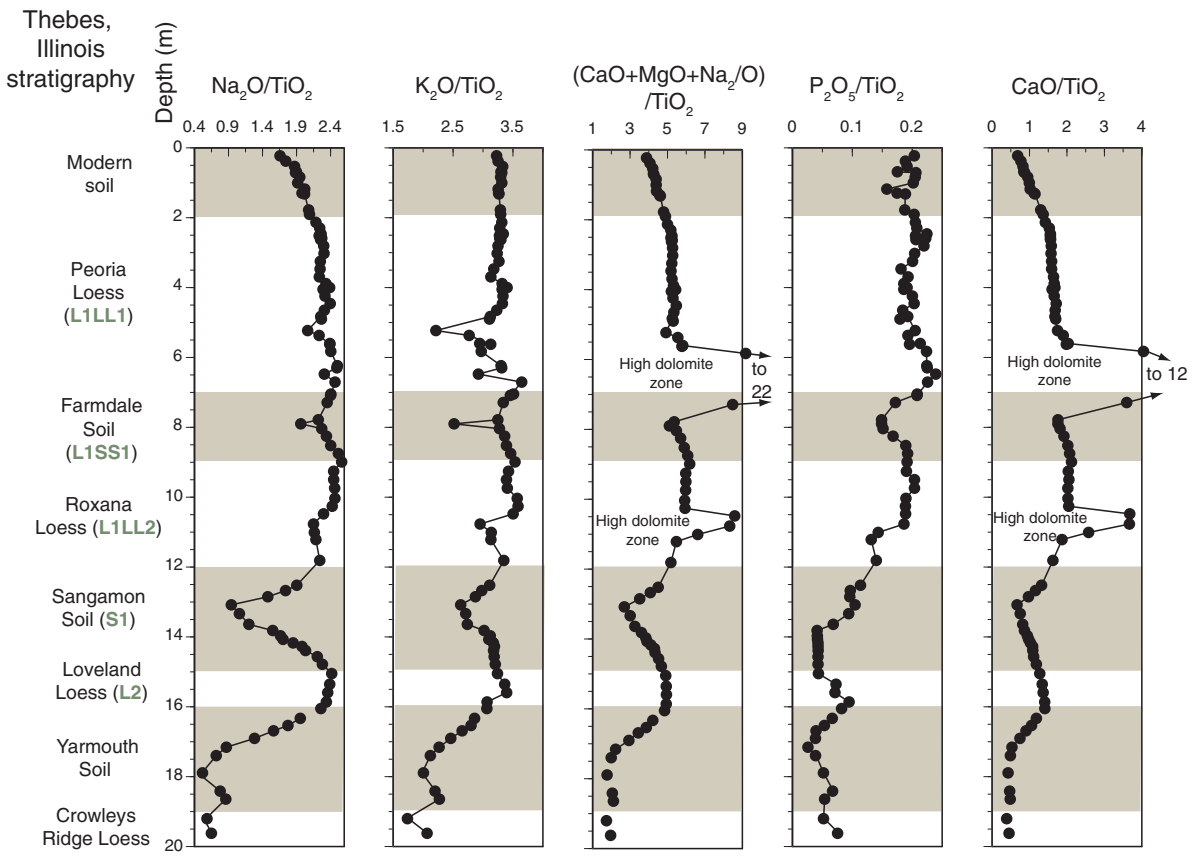

Fig. 30. Stratigraphy and changes in major element ratios $\left(\mathrm{CaO} / \mathrm{TiO}_{2}, \mathrm{Na}_{2} \mathrm{O} / \mathrm{TiO}_{2}, \mathrm{P}_{2} \mathrm{O}_{5} / \mathrm{TiO}_{2}, \mathrm{~K}_{2} \mathrm{O} / \mathrm{TiO}_{2}\right.$, and a chemical weathering index) in a loess section near Thebes, Illinois, USA (see Fig. 7 for location). Brown shaded zones represent paleosols; names in bold green font are probable equivalent units in the Chinese loess stratigraphic nomenclature. Stratigraphic data and some geochemical data are from Grimley et al. (2003); other geochemical data are from Muhs (2007). differences. Thorp et al. (1951), working in an era before modern geochronological methods were established, considered that the Sangamon Soil developed over a very long interglacial period. Ruhe (1969, p. 177) thought that both climate and time (i.e., greater moisture and warmth and a long period of pedogenesis) were factors that explained the greater degree of development of the Sangamon Soil. In a later study, however, Ruhe (1974) and Ruhe et al. (1974) seem to have favored climate as a factor, comparing the Sangamon Soil to the Ultisols of the southeastern U.S. This is essentially a scenario with an enhanced monsoonal flow of air to the North American midcontinent, similar to that described for China by Porter and An (1995) and illustrated in Fig. 31. Ruhe (1974) hypothesized that during Sangamon time, a greater residence time and intensity of monsoonal air flow from the Gulf of Mexico generated an "extension" of the subtropical Ultisol belt to the north (Fig. 31c). Hall and Anderson (2000), on the other hand, considered that the Sangamon Soil likely developed over a much longer period than the Holocene and that this explained the greater degree of development. Grimley et al. (2003) also considered that time was much more important than climate in explaining the greater degree of weathering of Sangamon Soils, and offered the possibility that Sangamon Soils developed over $\sim 50,000$ years whereas modern soils developed over $\sim 10,000$ years. Luminescence ages indicate that Loveland Loess along the lower Mississippi River valley accumulated between $\sim 184$ ka and $\sim 122$ ka (Markewich et al., 2011), correlating this sediment with Marine Isotope Stage (MIS) 6, using the chronology of Martinson et al. (1987), similar to the age of the L2 loess in China. Luminescence ages of $\sim 56 \mathrm{ka}$ to $\sim 34$ ka have been reported for Roxana Silt in the lower Mississippi River valley (Markewich et al., 2011). All these ages indicate that the Sangamon Soil in the lower Mississippi River valley could have been developing between $\sim 122 \mathrm{ka}$ and $\sim 56 \mathrm{ka}$, a time period of $\sim 66 \mathrm{ka}$. This is in good agreement with ${ }^{10} \mathrm{Be}$ accumulation-rate ages, also reported by Markewich et al. (2011) that indicate the Sangamon Soil could have been developing over a $60-80$ ka period. Thus, these reported ages indicate clearly that time is a major factor in the greater chemical weathering of the Sangamon Soil. However, Markewich et al. (2011) also indicate that they consider climate to have played an important role. This interpretation is supported by the findings of King and Saunders (1986), who reported the existence of Geochelone (giant tortoise) fossils in Sangamon-aged deposits in the State of Illinois in the Mississippi River valley. The presence of these animals in Illinois would require year-round temperatures above freezing, a condition significantly warmer than is the case at present.

Although the Sangamon Soil in North America correlates broadly with the S1 paleosol in China, there are some differences. In parts of China where loess sedimentation rates are high (see hypothetical example in Fig. 2 of Porter (2001)), the S1 paleosol can be subdivided into three separate paleosols, S1SS3 (=MIS 5.5), S1SS2 (=MIS 5.3), and S1SS1 (=MIS 5.1), separated by brief periods of loess deposition. Markewich et al. (2011) infer that periods of Sangamon Soil formation may have been episodic and they suggest that the two periods of soil formation occurred from $\sim 130-90 \mathrm{ka}$ (MIS 5.5, 5.4, 5.3, 5.2) and again from $\sim 74-58 \mathrm{ka}$ (MIS 4). At the Thebes locality shown in Fig. 30, it can only be inferred that there was a single, but perhaps long period of pedogenesis.

Some of the same characteristics in the Thebes, Illinois section are found at Lingtai, where the S1 paleosol also seems to be recorded as a single unit (Fig. 28). Compared to its modern soil, the S1 paleosol at Lingtai has greater depletions of carbonate minerals and plagioclase (as seen in the plots for $\mathrm{CaO} / \mathrm{TiO}_{2}, \mathrm{MgO} / \mathrm{TiO}_{2}$, and $\mathrm{Na}_{2} \mathrm{O} / \mathrm{TiO}_{2}$ ). Thus, it is possible that during $\mathrm{S} 1$ time (the last interglacial period) in China, there was an enhanced summer monsoon (Fig. 31b) or one that had a greater residence time, promoting greater chemical weathering. Like the North American midcontinent, however, time may have played a role in the greater weathering observed.

In the Great Plains loess belt, at a locality near Eustis, Nebraska (Fig. 7), there is a good example of a loess-paleosol sequence in a semiarid region. Whereas Thebes, Illinois, described above, has a present mean annual precipitation of $\sim 1200 \mathrm{~mm}$, Eustis, Nebraska has a present mean annual precipitation of $\sim 550 \mathrm{~mm}$, less than half that of the Thebes area. Eustis and Thebes have the same upper three loess stratigraphic units, from youngest to oldest, Peoria Loess, Roxana Loess (called the "Gilman Canyon Formation" in the Great Plains), and Loveland Loess (Fig. 32). Optically stimulated luminescence (OSL), thermoluminescence (TL), and radiocarbon ages of the three loess units at Eustis (Fig. 32) show the same ages as those reported for these units in the Mississippi River valley (see ages in Bettis et al. (2003) and Markewich et al. (2011)). In the modern soil at Eustis, there are slight depletions of $\mathrm{Na}_{2} \mathrm{O}$ relative to $\mathrm{TiO}_{2}$ in the subsoil and slight depletions of $\mathrm{K}_{2} \mathrm{O}$ in surface horizons. Apatite weathering in the modern soil is 

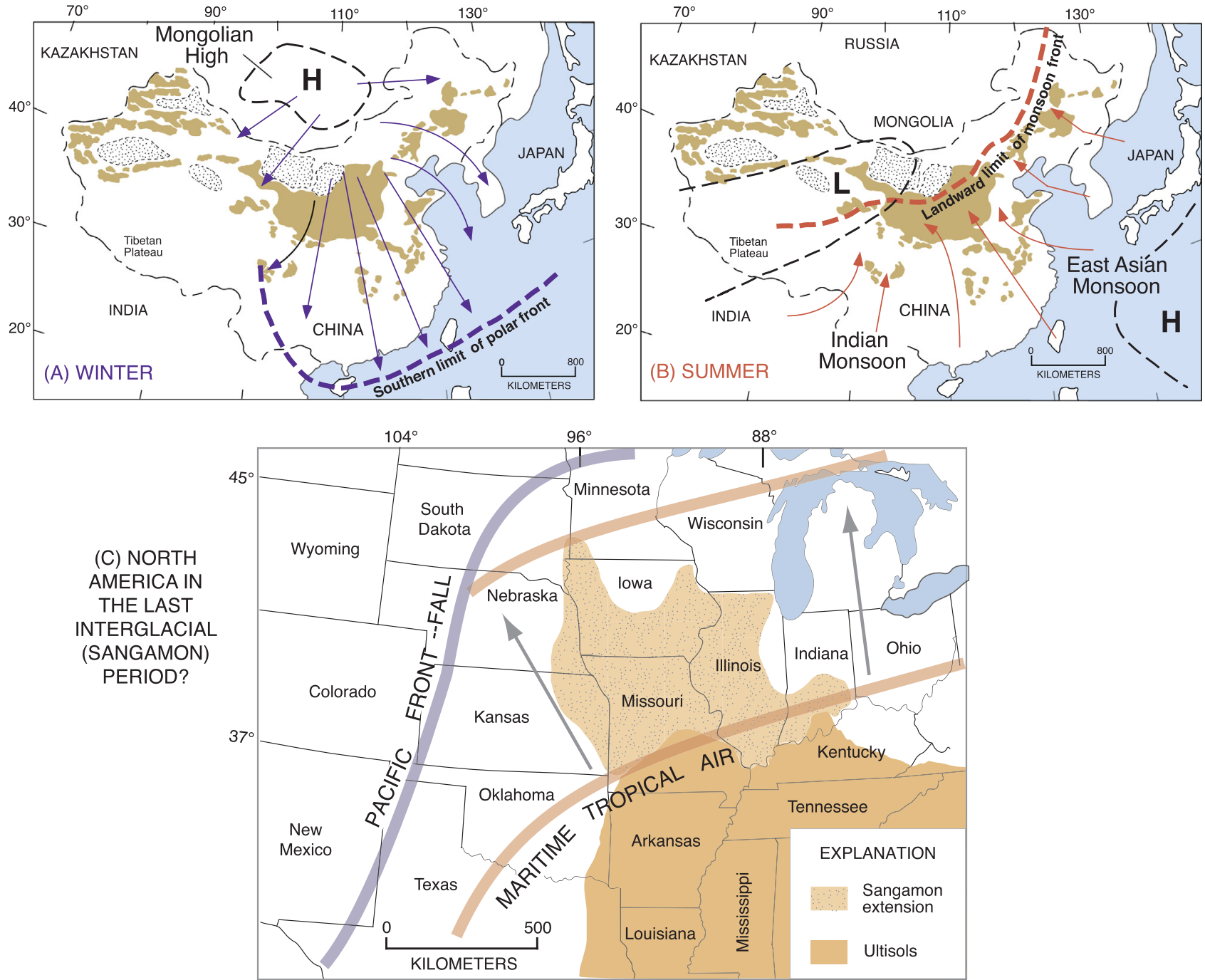

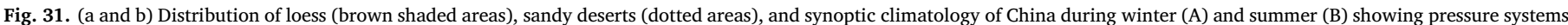

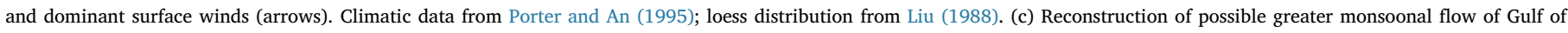

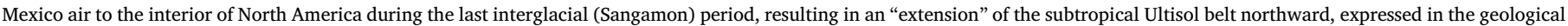
record of loess as the Sangamon Soil. Redrawn from Ruhe (1974).

indicated by lower $\mathrm{P}_{2} \mathrm{O}_{5} / \mathrm{TiO}_{2}$ values. Loss of carbonate minerals, calcite and dolomite, is indicated by low $\mathrm{CaO} / \mathrm{TiO}_{2}$ values in the upper part of the modern soil, but a calcic horizon has accumulated here, as indicated by higher $\mathrm{CaO} / \mathrm{TiO}_{2}$ values in the lower part of the modern soil. The upper part of the paleosol portion of the Gilman Canyon Formation shows that weathering of plagioclase, mica, apatite, and carbonate minerals occurred, as indicated by lower values of $\mathrm{Na}_{2} \mathrm{O}$ / $\mathrm{TiO}_{2}, \mathrm{~K}_{2} \mathrm{O} / \mathrm{TiO}_{2},\left(\mathrm{CaO}+\mathrm{MgO}+\mathrm{Na}_{2} \mathrm{O}\right) / \mathrm{TiO}_{2}, \mathrm{P}_{2} \mathrm{O}_{5} / \mathrm{TiO}_{2}$, and $\mathrm{CaO} / \mathrm{TiO}_{2}$ relative to the lower horizons of this paleosol (Fig. 32). The same is true for the Sangamon Soil except that it too, like the modern soil, has a well-developed calcic horizon, with very high $\mathrm{CaO} / \mathrm{TiO}_{2}$ values. Thus, although the Sangamon Soil at Thebes is leached of carbonates throughout its depth, at Eustis this soil has experienced a net accumulation of secondary carbonates, visible in the field as coatings on ped faces and pore fillings. These observations suggest that the present humid to semiarid precipitation gradient, going west from the Mississippi River valley to the Great Plains, likely also existed at the time of Sangamon Soil formation, during the last interglacial period and afterward. This inference requires more testing using data from a greater number of localities along this moisture gradient, but is worthy of further study. A similar sort of study could be done with the S1 (last interglacial paleosol) on the Chinese Loess Plateau (Fig. 2), where a north-to-south (arid to humid) moisture gradient also exists.
It has been axiomatic in geology and pedology that rates of chemical weathering and/or soil formation should be greatly diminished in colder climates. Indeed, Van't Hoff's Law states that for each $10^{\circ} \mathrm{C}$ rise in temperature, rates of chemical reactions should increase between two and three times. Thus, the reverse of this would be that in cold climates, rates of chemical reactions, including rates of mineral weathering, should diminish compared to those in mid-latitudes or low latitudes. Anderson (2007) reviewed this topic and pointed out that chemical weathering in cold climates is in fact greatly diminished, but under favorable circumstances, chemical weathering can proceed. There have been a number of studies of loess and loess-derived soils in Alaska, with some offering evidence that there is little or no measurable chemical weathering and other studies indicating that chemical weathering is significant (see review in Muhs et al., 2008c).

A final example from North America given here represents the loess record of past pedogenesis in a subarctic environment at high latitude in central Alaska (Fig. 33). Detailed study of loess exposures in central Alaska confirms that paleosols do exist in these sections (an observation not always accepted by some Alaskan investigators in the past) and chemical weathering has taken place within these buried soils (Muhs et al., 2003, 2008c). Muhs et al. (2008c) showed that plagioclase has been lost during pedogenesis of both modern and buried soils. This is expressed both in plots of $\mathrm{Na}_{2} \mathrm{O} / \mathrm{TiO}_{2}$ (Fig. 33) and $\mathrm{SiO}_{2} / \mathrm{TiO}_{2}$ (not 

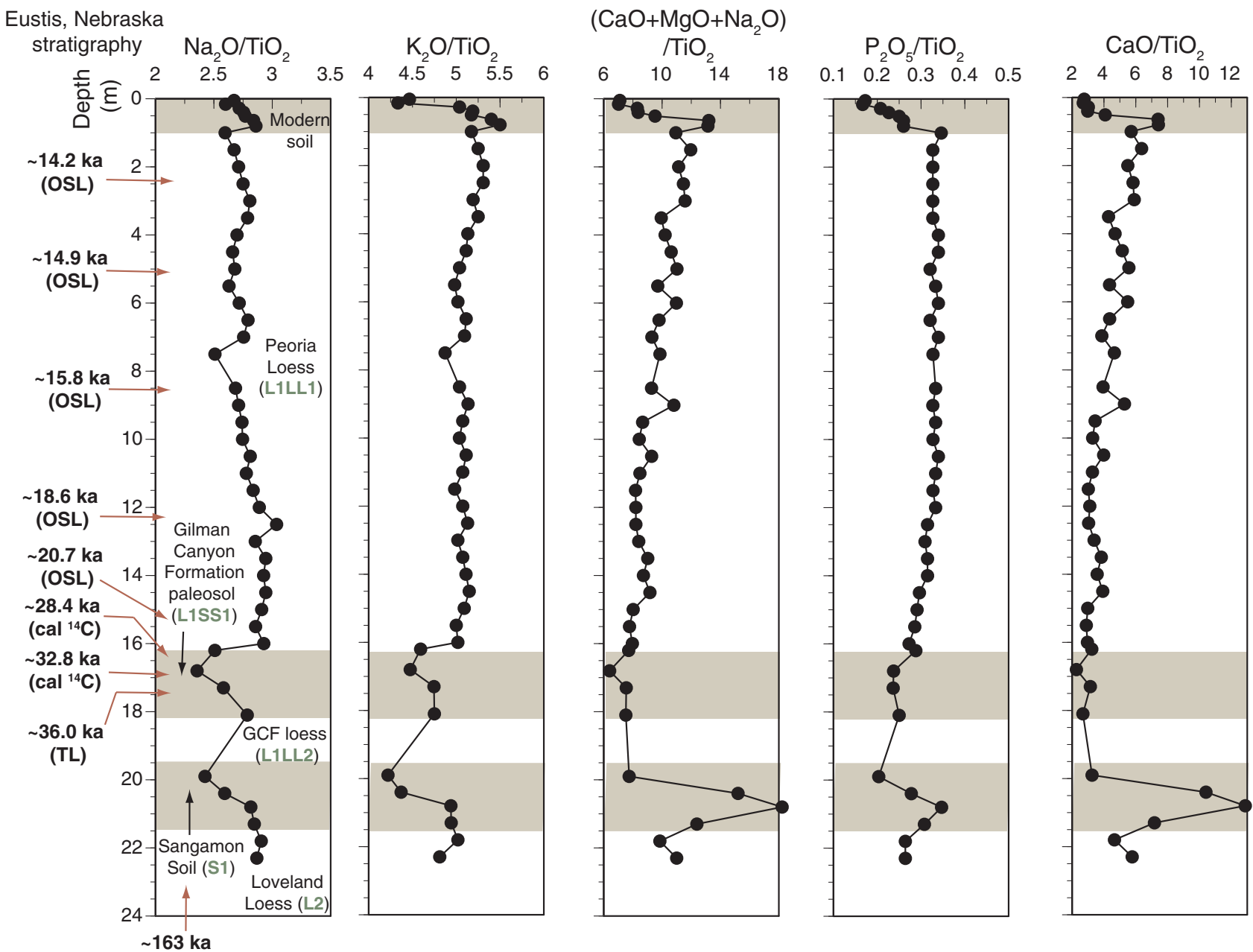

(TL)

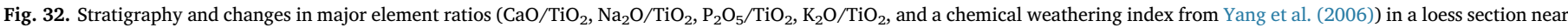

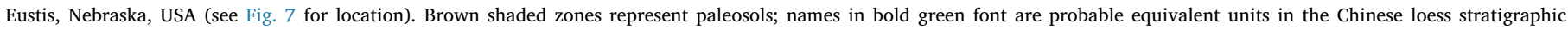

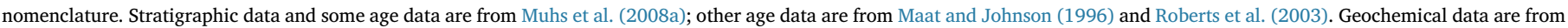
Muhs et al. (2008a; see Supplementary Data).

shown here, but see Muhs et al. (2008c), their Fig. 6 for the same loess section). All paleosols shown in Fig. 33 show depletions of $\mathrm{Na}_{2} \mathrm{O} / \mathrm{TiO}_{2}$ relative to underlying loess deposits that are the likely soil parent materials. Bulk mineralogical studies by Muhs et al. (2008c) show that plagioclase/quartz plots parallel those of $\mathrm{Na}_{2} \mathrm{O} / \mathrm{TiO}_{2}$, indicating that $\mathrm{Na}_{2} \mathrm{O} / \mathrm{TiO}_{2}$ is faithfully recording plagioclase losses. The $\mathrm{K}_{2} \mathrm{O} / \mathrm{TiO}_{2}$ plot shows depletion of some K-bearing mineral or minerals in most (but not all) paleosols. It is likely that silt- and clay-sized muscovite is one of the K-bearing minerals being depleted. This mineral is abundant in the silt fraction and is visible in hand specimens. X-ray diffractometry studies show that mica is present in the clay fraction as well and loss of this mineral could explain some of the lower $\mathrm{K}_{2} \mathrm{O} / \mathrm{TiO}_{2}$ values. Loss of apatite is apparent in the $\mathrm{P}_{2} \mathrm{O}_{5} / \mathrm{TiO}_{2}$ data of the loess section in most of the paleosols, although not in the upper part of the modern soil (Fig. 33). This is expected, however, as $\mathrm{P}$ concentrations tend to be high in unweathered parent material (too deep for leaching), low in the lower horizons of the soil (where $\mathrm{P}$ is either leached or taken up by plants), and high again in upper horizons where it is recycled by plants (Runge et al., 1974).

Evidence for other mineral depletions represented by the element ratios comes from comparisons of soil and paleosol compositions and the compositions of silts in fluvial source sediments. Muhs and Budahn (2006), using immobile trace element geochemistry, showed that central Alaskan loesses near Fairbanks (Fig. 10) are derived from a mix of sediments from at least three rivers, the most important of which are the Tanana River and the Yukon River. Based on clay mineralogical studies by Muhs et al. (2008c), smectite is an important species among the clay minerals found in these fluvial sediments. Modern, loess-derived soils in the area contain only small amounts of smectite, if any, and paleosols contain virtually no smectite. These observations indicate that smectite was likely originally present in the loess, but during pedogenesis has been depleted. The same line of reasoning applies to the presence or absence of carbonate minerals. Based on detailed mineralogical studies by Eberl (2004), both calcite and dolomite are present in the modern floodplain sediments of the Tanana River and Yukon River. Depletion of these minerals in the modern soils and paleosols in this area is indicated by both the $\mathrm{CaO} / \mathrm{TiO}_{2}$ values and the chemical weathering index of Yang et al. (2006), $\left(\mathrm{CaO}+\mathrm{MgO}+\mathrm{Na}_{2} \mathrm{O}\right) /$ $\mathrm{TiO}_{2}$ (Fig. 33). Both of these weathering indicators show varying amounts of depletion in paleosols relative to underlying loesses, part of which can be explained by depletion of calcite and dolomite during pedogenesis. Although Muhs et al. (2008c) did not have Ti data for fluvial sediments of the Tanana River and Yukon River, they did have $\mathrm{CaO}$ and $\mathrm{ZrO}_{2}$ abundances for both the river sediments and the loess sections. Their calculated $\mathrm{CaO} / \mathrm{ZrO}_{2}$ values in the loess sections, whether they are in the paleosols or in "unaltered" loess show values that are, with few exceptions, lower than all but the very lowest values in sediments from both rivers. This observation suggests the possibility 

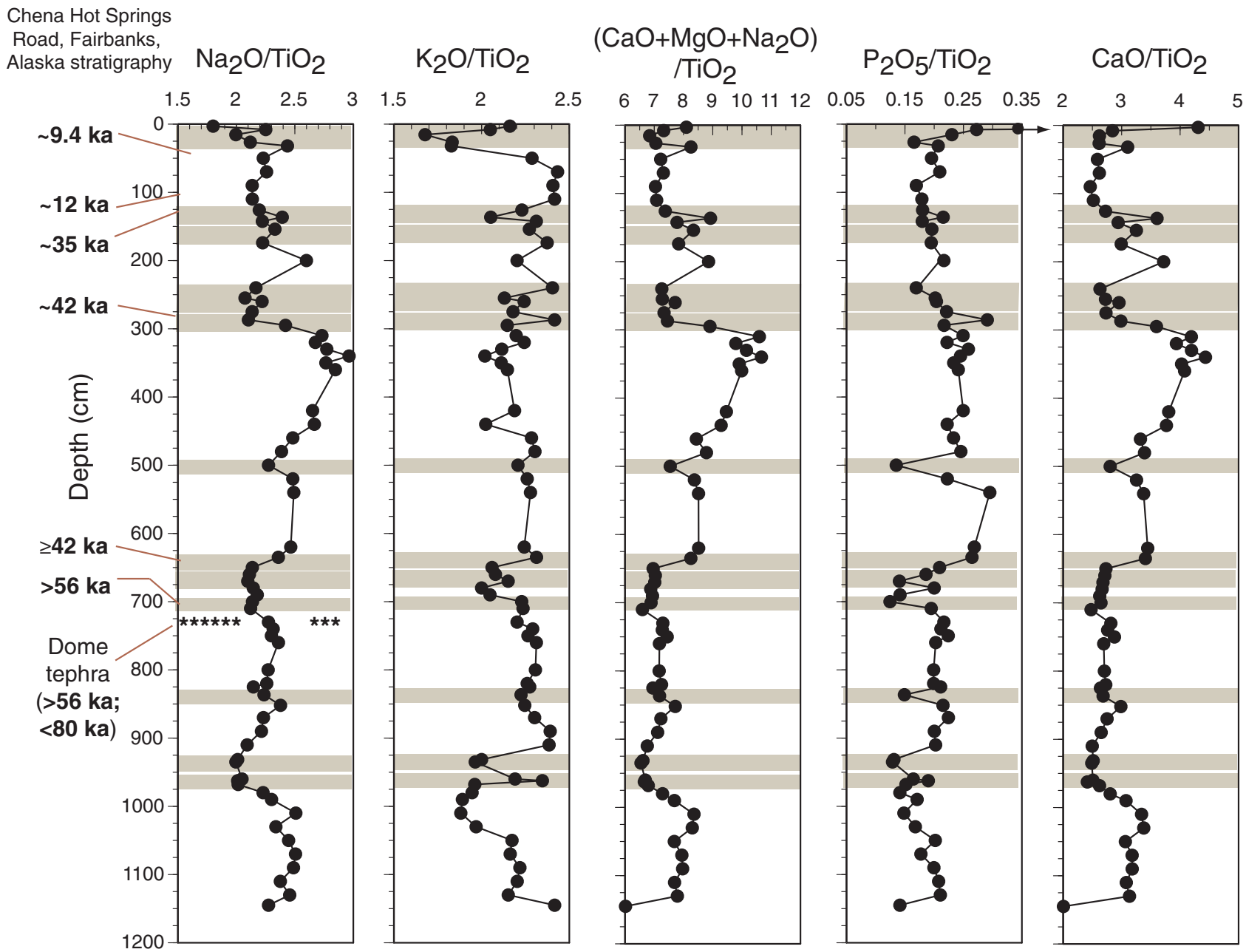

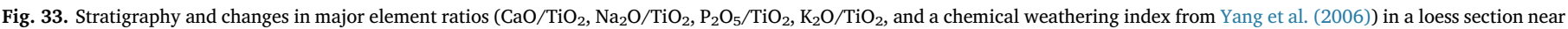

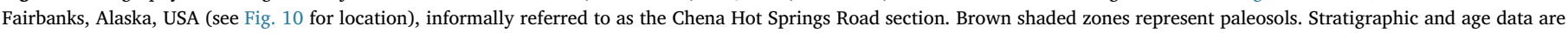
from Muhs et al. (2003, 2008c).

that loess in this area was originally calcareous, but experienced carbonate mineral loss syndepositionally, even before periods of stability and pedogenesis. Muhs et al. (2008c) infer, therefore that even during periods of active loess accumulation, the vegetation in the region was acidic enough (i.e., either boreal forest or moist, acidic tundra) that through-leaching of carbonates could be accomplished, although carbonate solubility would also be enhanced under cooler paleotemperatures.

The observations from Alaska show that loess-derived soils can experience chemical weathering even under the subarctic climate of a high-latitude region. A worthwhile study would be to determine if Asia has comparable evidence of chemical weathering in loess-derived soils and paleosols. An obvious target for such research would be the loess deposits of Siberia, including the area of Yakutia along the Aldan and Lena Rivers (Fig. 1) and along the Arctic Ocean coastal plain of Russia. Another potentially fruitful area for study would be the high-altitude (analogous to high-latitude) loess deposits and intercalated paleosols in the mountains of northwestern China. In the northern Tian Shan (Fig. 2), loess is found as high as $2400 \mathrm{~m}$ above sea level and paleosols are reported in these deposits (Sun, 2002b). In the northern Kunlun Shan (Fig. 2), loess is found between $2500 \mathrm{~m}$ and $5300 \mathrm{~m}$; although paleosols are reported to be rare (Sun, 2002b), detailed exploration might reveal loess-paleosol records worth investigating.

\section{Summary}

Loess is widely distributed over Asia and constitutes one of the most important surficial deposits on that continent. It is found in China, Russia, and several countries in Central Asia, but has been mapped the most carefully and studied in the most detail in China. Pleistocene loess has accumulated to tremendous thicknesses in parts of Asia. In parts of Tajikistan, loess can be as much as $\sim 100 \mathrm{~m}$ thick and in the northwestern parts of the Loess Plateau of China, thicknesses of more than $\sim 300 \mathrm{~m}$ have been measured. The oldest Pleistocene loess in China is likely $\sim 2.6 \mathrm{Ma}$, thus spanning much or all of the Pleistocene. In addition, older Tertiary "red clays," now interpreted to be largely or wholly of aeolian origin, underlie the oldest Pleistocene loess and may span several millions of years of aeolian accretion.

Despite the long history of loess accretion in Asia, deposition was not continuous. Paleosols intercalated within the loess indicate periods when deposition rates were lower, such that loess sedimentation slowed to the point where rates of pedogenesis exceeded rates of dust deposition. In China and Tajikistan, periods of loess accumulation have been linked to glacial periods and periods of soil formation to interglacial periods. However, dust deposition probably continued even during times of pedogenesis and vice versa, and investigators have referred to loess accumulation and pedogenesis as competing processes.

Geochemistry is the key to identifying which rock types have been 
most important in generating the dust that accumulates as loess. Mountains in China contain an astounding diversity of rock types that can contribute particles to loess. These include granitic plutons, gneisses, amphibolites, sandstones, conglomerates, volcanic rocks, and carbonate rocks. Desert basins of western and northern China, long thought to be the source areas for loess, receive sediments from an extremely wide range of rock types, with granitic rocks always being a primary, but not sole contributor.

In most of North America, loess does not have the long history that is evident in Asia, with the exception of Alaska, where the record may go back to $\sim 3.0 \mathrm{Ma}$. Elsewhere, the oldest widespread loess that is preserved is that from the penultimate glacial period. Loess in the greater Mississippi River valley of midcontinental North America is dominantly glacially derived, deflated from outwash along major river valleys that drained the Laurentide Ice Sheet. Lobes of the Laurentide Ice Sheet eroded different bedrock terrains in North America, including Precambrian crystalline rocks (granites and gneisses), but also carbonate rocks and shales. West of the Missouri River, in the Great Plains region, loess is dominantly non-glaciogenic. Two contributors are important: felsic Tertiary volcaniclastic siltstones of the White River Group and silts from a variety of fluvial sources, most importantly the Platte River system that drains Precambrian crystalline rocks of the Rocky Mountains.

In spite of the different source sediments for loess in the Mississippi River valley and the Great Plains, the youngest loess deposits are of broadly similar age and date to the late last glacial period (MIS 2, or Chinese equivalent L1LL1), the early last glacial period (MIS 4, or Chinese equivalent L1LL2), and the penultimate glacial period (MIS 6, or Chinese equivalent L2). Paleosols formed between times of loess deposition, similar to those in China. However, unlike Asia, older, preMIS 6 loess deposits are rare in midcontinental North America, and where present are thin, possibly the result of widespread erosion and/or significant dust production only during later glacial periods of the Quaternary.

In Alaska, loess is dominantly glaciogenic and glacial flour produces dust storms and loess accumulation continues to this day. Derivation of loess comes from glacial erosion of rocks that compose a series of accreted terranes and lithologies are diverse, ranging from granitic intrusions to very young mafic volcanic rocks and a large suite of metasedimentary rocks of mafic to felsic composition. Unlike the North American midcontinent, loess in Alaska has some similarities to Asia in that the record is much longer and loess accumulation is not simply a "turn on" (glacial periods) and "turn off" (interglacial periods) cycle. In Alaska, there is accumulation of fine-grained particles even when pedogenesis is dominant and there is syndepositional weathering when loess accumulation is dominant.

The major element composition of loess is a function of its mineralogy and has similarities to, but is not identical to average upper continental crust, except at the broadest level of generalization. Indeed, there are regional differences in major element concentrations that are indicative of distinctive mineralogy and specific source rocks for different loess bodies. In Asia, higher concentrations of carbonate minerals are apparent from high concentrations of $\mathrm{CaO}$ and $\mathrm{MgO}$ in loess of Tajikistan, whereas loess in Yakutia has low concentrations of these elements and low concentrations of carbonate minerals. Deposits in the Chinese Loess Plateau have intermediate amounts of $\mathrm{CaO}$ and $\mathrm{MgO}$. The reverse is true for concentrations of plagioclase and K-feldspar/mica: these minerals are most abundant in loess of Yakutia, based on concentrations of $\mathrm{Na}_{2} \mathrm{O}$ and $\mathrm{K}_{2} \mathrm{O}$, and least abundant in loess of Tajikistan. The same kind of regional differences are apparent in North America: Mississippi River valley loess has high amounts of carbonate minerals and therefore high $\mathrm{CaO}$ and $\mathrm{MgO}$, whereas central Alaskan loess has low concentrations of carbonate minerals and low $\mathrm{CaO}$ and $\mathrm{MgO}$. These observations show that loess bodies are not all uniform, monotonous replicas of average upper continental crust, but have distinctive compositions that reflect different source rocks.
In addition to being regionally distinctive, there is spatial variation of sediment geochemistry of loess within a region. Abundances of $\mathrm{SiO}_{2}$ and $\mathrm{Na}_{2} \mathrm{O}$ decrease to the southeast from the Mu Us desert margin to the northern Chinese Loess Plateau, as coarse-grained quartz and plagioclase are winnowed. In contrast, clay mineral content increases downwind, to the southeast, and this is reflected in higher $\mathrm{Fe}_{2} \mathrm{O}_{3}$ contents. In the North American midcontinent, similar spatial trends in loess geochemistry are also apparent, moving eastward from loess sources such as the Missouri River.

Plots of $\log \left[\left(\mathrm{CaO}+\mathrm{Na}_{2} \mathrm{O}\right) / \mathrm{K}_{2} \mathrm{O}\right]$ vs. $\log \mathrm{SiO}_{2} / \mathrm{Al}_{2} \mathrm{O}_{3}$ provide a geochemical portrayal of three of the most abundant sedimentary rocks on the Earth: sandstones, shales, and carbonate rocks. Most loess bodies plot between the fields for sandstones and shales, but some plot away from these fields and towards the field for carbonate rocks due to greater inputs of calcite and dolomite from carbonate source rocks. Another useful graphical portrayal of sedimentary rocks is $\mathrm{K}_{2} \mathrm{O} / \mathrm{Al}_{2} \mathrm{O}_{3}$ vs. $\mathrm{Na}_{2} \mathrm{O} / \mathrm{Al}_{2} \mathrm{O}_{3}$. This plot is particularly useful for comparing the nature of igneous rock input (mafic vs. felsic) to a loess body and the degree of fine-grained sedimentary or metasedimentary rock input (shales and slates) to a loess body. Almost all loess bodies plot below the fields for igneous rocks, indicating that most all of them are not simply "ground-up igneous rocks," but have components derived from second-cycle (or later) sediments that have experienced some loss of $\mathrm{Na}_{2} \mathrm{O}$ relative to $\mathrm{Al}_{2} \mathrm{O}_{3}$. Loess bodies from different parts of China show distinctive compositions along this axis, indicating that some loess sediments are more directly derived from igneous rocks than others. The same is true for loess bodies in North America, where some fall within the igneous rock field, but most do not. Furthermore, contributions from igneous rock types can be discerned from such plots, where some loess bodies have more mafic source rocks than others.

Trace elements also have tremendous power in deciphering loess sources. Chief among these are relatively immobile trace elements such as Sc, Th, Zr and the REE. Ternary plots of Sc-Th-La and Zr-Sc-Th are particularly useful in determining the degree of mafic vs. felsic rock inputs. Most Asian loesses clearly have felsic source rocks, suggesting dominantly rocks of granitic composition as sources, whereas others have had more inputs from rocks of mafic composition. In North America, loess bodies from different parts of the continent show a considerable range of mafic to felsic source materials based on Sc-Th-La and $\mathrm{Zr}$-Sc-Th plots.

Rare earth elements are among the most useful trace elements for provenance studies in loess. REE compositions of loess in Asia show both similarities and differences between regions. Loess in the Harbin region of northeastern China has similar REE compositions to silts on the Chinese Loess Plateau. However, loess from the Qinling Mountains shows only partial overlap with the Chinese Loess Plateau and loess from Tibet shows no overlap at all, having a much more felsic signature. Fewer studies of the REE composition of loess in North America have been conducted, but some data are available that allow for identification of regional distinctiveness in loess. Loess from the Great Plains, the fine-grained $(<20 \mu \mathrm{m})$ component of Mississippi River valley loess, and loess from central Alaska all show considerable overlap with the Chinese Loess Plateau, demonstrating a dominantly average upper continental crustal REE composition. However, loess from other localities in Alaska have distinctive compositions on $\mathrm{La}_{\mathrm{N}} / \mathrm{Yb}_{\mathrm{N}} \mathrm{Vs}$. $\mathrm{Eu} / \mathrm{Eu}^{*}$ plots, indicating more mafic source rocks.

Part of the richness of the loess-paleosol stratigraphic record stems from its ability not only to document past atmospheric circulation during glacial periods (the loess component of the record), but also past vegetation and moisture regime during interglacials (the paleosol component of the record). One of the most effective means of elucidating past interglacial moisture regimes is to examine the geochemistry of loess-derived paleosols, because this composition reflects the degree of mineral alteration. Virtually all mineral-alteration processes of a chemical nature require water, so degree of mineral alteration, represented by geochemistry, says much about overall moisture regime 
during the period of soil formation.

A soil climosequence study in the Mississippi River valley of North America shows that the geochemistry of loess-derived modern soils shows a strong reliance on climate. Profile averaged $\mathrm{CaO} / \mathrm{TiO}_{2}, \mathrm{MgO}$ / $\mathrm{TiO}_{2}, \mathrm{Na}_{2} \mathrm{O} / \mathrm{TiO}_{2}$, and $\mathrm{K}_{2} \mathrm{O} / \mathrm{TiO}_{2}$ all show strong negative relations with present mean annual precipitation, indicating that the degree of mineral alteration increases with increased precipitation. Trace element ratios that represent these same minerals, $\mathrm{Sr} / \mathrm{Zr}, \mathrm{Rb} / \mathrm{Zr}$, and $\mathrm{Ba} / \mathrm{Zr}$ also show decreases in values with increasing precipitation. These observations show that simple mobile-to-immobile element ratios can be powerful tools in interpreting degree of mineral alteration in paleosols.

In Asia, detailed geochemical studies of long-term loess-paleosol records have been carried out in the Chinese Loess Plateau and in Tajikistan. These records show significant mineral depletions in all paleosols relative to the underlying loess parent materials. On the Chinese Loess Plateau, paleosols from the previous five interglacials all show greater mineral depletions than their modern soil counterparts, indicating greater moisture during those times, a longer period of chemical weathering, or both. Prior to $\sim 600 \mathrm{ka}$, however, the degree of mineral alteration is even greater and differences between interglacials and glacials, with respect to mineral weathering, are greatly diminished overall. These data are interpreted to reflect a greater degree of weathering of source materials prior to $\sim 600 \mathrm{ka}$ during both glacials and interglacials. This different weathering regime in the early Pleistocene is considered to be due not only to orbital forcing (which generated shorter interglacial-glacial cycles at this time), but also was a time prior to complete uplift of the Tibetan Plateau, which later blocked tropical moisture from reaching China's interior, increasing aridity and decreasing weathering.

In North America, the record of earlier loess accumulation and paleosol formation does not go back nearly as far as in Asia and the only widespread paleosol is the Sangamon Soil. This paleosol appears to have developed over a long time period, during all of MIS 5 and likely at least part of MIS 4. In the relatively humid Mississippi River valley, as on the Loess Plateau, it exhibits a significant degree of mineral alteration with losses of carbonate minerals, plagioclase, mica, and apatite (from $\mathrm{Na}_{2} \mathrm{O} / \mathrm{TiO}_{2}, \mathrm{CaO} / \mathrm{TiO}_{2}, \mathrm{~K}_{2} \mathrm{O} / \mathrm{TiO}_{2}$, and $\mathrm{P}_{2} \mathrm{O}_{5} / \mathrm{TiO}_{2}$ ). In addition to time, however, the last interglacial period may have been warmer and more humid, with a strengthened monsoon, analogous to the summer monsoon of China, which would have enhanced mineral weathering in the Sangamon Soil. In the semiarid Great Plains, the Sangamon Soil shows only modest evidence of plagioclase, mica, and apatite depletion but evidence of subsoil accumulation of carbonates in a calcic horizon. This suggests that the east-to-west, humid to semiarid moisture gradient from the Mississippi River valley that is present today also existed during the last interglacial period. This hypothesis is worthy of more detailed testing in North America and is one that could also be tested along the moisture gradient of the Chinese Loess Plateau. In any such study, just as in those described throughout this review, major and trace element geochemistry, combined with traditional stratigraphy and mineralogy, will be critical tools in deciphering the geologic record.

\section{Acknowledgments}

I thank Jimin Sun, Liping Zhou, Edward Derbyshire, and Ann Wintle for inviting me to contribute this paper, which is an honor. The Climate and Land Use Change Program of the U.S. Geological Survey supports my work. This paper is dedicated to two people. One of these is Professor Liu Tungsheng of the Chinese Academy of Sciences. His pioneering work on loess and his book Loess in China have been an inspiration for my own work on loess in North America. The other person to whom I would like to dedicate the paper is the late Robert L. Muhs, my father, who has two geographic connections to the study. Bob Muhs spent the first 20 years and last 30 years of his life in Camanche, Iowa, in the loess country along the upper Mississippi River that he loved so much. During World War II, he spent 1944 and 1945 in the U.S. Army
Air Forces in China, stationed at various times in Guilin, Zhijiang, Chengdu, and Xi'an. Special thanks go to Jimin Sun, who kindly provided trace element data for loess he studied from various parts of China, and for his invitation, encouragement (and patience) in bringing this paper to completion. Art Bettis (University of Iowa), an anonymous journal reviewer, Margaret Redsteer and Janet Slate (both U.S. Geological Survey) made helpful comments on an earlier version of the paper, which I appreciate. Any use of trade, product or firm names is for descriptive purposes only and does not imply endorsement by the U.S. Government.

\section{References}

Ahmad, I., Chandra, R., 2013. Geochemistry of loess-paleosol sediments of Kashmir Valley, India: provenance and weathering. J. Asian Earth Sci. 66, 73-89.

Aleinikoff, J.N., Muhs, D.R., Sauer, R., Fanning, C.M., 1999. Late Quaternary loess in northeastern Colorado, II. Pb isotopic evidence for the variability of loess sources. Geol. Soc. Am. Bull. 111, 1876-1883.

Aleinikoff, J.N., Muhs, D.R., Bettis III, E.A., Johnson, W.C., Fanning, C.M., Benton, R., 2008. Isotopic evidence for the diversity of late Quaternary loess in Nebraska: glaciogenic and non-glaciogenic sources. Geol. Soc. Am. Bull. 120, 1362-1377.

Anderson, S.P., 2007. Biogeochemistry of glacial landscape systems. Annu. Rev. Earth Planet. Sci. 35, 375-399.

Bettis III, E.A., Muhs, D.R., Roberts, H.M., Wintle, A.G., 2003. Last glacial loess in the conterminous USA. Quatern. Sci. Rev. 22, 1907-1946.

Bhatia, M.R., Crook, K.A.W., 1986. Trace element characteristics of graywackes and tectonic setting discrimination of sedimentary basins. Contrib. Miner. Petrol. 92, 181-193.

Birkeland, P.W., 1999. Soils and Geomorphology. Oxford University Press, New York, pp. 430.

Brown, J., Ferrians Jr., O.J., Heginbottom, J.A., Melnikov, E.S., 1997. Circum-Arctic map of permafrost and ground-ice conditions. U.S. Geological Survey Map CP-45, scale $1: 10,000,000$.

Bryan, K., 1945. Glacial versus desert origin of loess. Am. J. Sci. 243, 245-248.

Budahn, J.R., Schmitt, R.A., 1985. Petrogenetic modeling of Hawaiian tholeiitic basalts: a geochemical approach. Geochim. Cosmochim. Acta 49, 67-87.

Burbank, D.W., Li, Jijun., 1985. Age and palaeoclimatic significance of the loess at Lanzhou, North China. Nature 316, 429-431.

Busacca, A.J., McDonald, E.V., 1994. Regional sedimentation of late Quaternary loess on the Columbia Plateau: sediment source areas and loess distribution patterns. Washington Div. Geol. Earth Resour. Bull. 80, 181-190.

Chamberlin, T.C., 1897. Supplementary hypothesis respecting the origin of the loess of the Mississippi Valley. J. Geol. 5, 795-802.

Chen, F., Li, Jijun., 1991. Loess stratigraphy of the Lanzhou profile and its comparison with deep-sea sediment and ice core record. GeoJournal 24, 201-209.

Chlachula, J., 2003. The Siberian loess record and its significance for reconstruction of Pleistocene climate change in north-central Asia. Quatern. Sci. Rev. 22, 1879-1906.

Crusius, J., Schroth, A.W., Gassó, S., Moy, C.M., Levy, R.C., Gatica, M., 2011. Glacial flour dust storms into the Gulf of Alaska: hydrologic and meteorological controls and their importance as a source of bioavailable iron. Geophys. Res. Lett. 38. http://dx.doi. org /10.1029/2010GL046573.

Derbyshire, E., 1983. On the morphology, sediments, and origin of the Loess Plateau of central China. In: Gardner, R., Scoging, H. (Eds.), Mega-Geomorphology. Clarendon Press, Oxford, pp. 172-194.

Derbyshire, E., Meng, X., Kemp, R.A., 1998. Provenance, transport and characteristics of modern aeolian dust in western Gansu Province, China, and interpretation of the Quaternary loess record. J. Arid Environ. 39, 497-516.

Ding, Z.L., Liu, T.S., Rutter, N.W., Yu, Z.W., Guo, Z.T., Zhu, R.X., 1995. Ice-volume forcing of East Asian winter monsoon variations in the past 800,000 years. Quatern. Res. 44, 149-159.

Ding, Z.L., Sun, J.M., Liu, T.S., Zhu, R.X., Yang, S.L., Guo, B., 1998. Wind-blown origin of the Pliocene red clay formation in the central Loess Plateau, China. Earth Planet. Sci. Lett. 161, 135-143.

Ding, Z.L., Sun, J.M., Yang, S.L., Liu, T.S., 2001. Geochemistry of the Pliocene red clay formation in the Chinese Loess Plateau and implications for its origin, source provenance and paleclimate change. Geochim. Cosmochim. Acta 65, 901-913.

Ding, Z.L., Derbyshire, E., Yang, S.L., Yu, Z.W., Xiong, S.F., Liu, T.S., 2002a. Stacked 2.6Ma grain size record from the Chinese loess based on five sections and correlation with the deep-sea $\mathrm{d}^{18} \mathrm{O}$ record. Paleoceanography 17, 1033. http://dx.doi.org/10. 1029/2001PA000725.

Ding, Z.L., Ranov, V., Yang, S.L., Finaev, A., Han, J.M., Wang, G.A., 2002b. The loess record in southern Tajikistan and correlation with Chinese loess. Earth Planet. Sci. Lett. 200, 387-400.

Ding, Z.L., Derbyshire, E., Yang, S.L., Sun, J.M., Liu, T.S., 2005. Stepwise expansion of desert environment across northern China in the past 3.5 Ma and implications for monsoon evolution. Earth Planet. Sci. Lett. 237, 45-55.

Dodonov, A.E., 2007. Central Asia. In: Elias, S. (Ed.), The Encyclopedia of Quaternary Sciences. Elsevier, Amsterdam, pp. 1418-1429.

Dodonov, A.E., Sadchikova, T.A., Sedov, S.N., Simakova, A.N., Zhou, L.P., 2006. Multidisciplinary approach for paleoenvironmental reconstruction in loess-paleosol studies of the Darai Kalon section, southern Tajikistan. Quatern. Int. 152-153, 48-58. Dyke, A.S., Andrews, J.T., Clark, P.U., England, J.H., Miller, G.H., Shaw, J., Veillette, J.J., 
2002. The Laurentide and Innuitian ice sheets during the last glacial maximum. Quatern. Sci. Rev. 21, 9-31.

Eberl, D.D., 2004. Quantitative mineralogy of the Yukon River system: changes with reach and season, and determining sediment provenance. Am. Miner. 89, 1784-1794.

Eden, D.N., Qizhong, W., Hunt, J.L., Whitton, J.S., 1994. Mineralogical and geochemical trends across the Loess Plateau, North China. Catena 21, 73-90.

Fang, X., Liu, D., Song, C., Dai, S., Meng, Q., 2013. Oligocene slow and MioceneQuaternary rapid deformation and uplift of the Yumu Shan and North Qilian Shan: evidence from high-resolution magnetostratigraphy and tectonosedimentology. Geol. Soc. Lond. Spec. Publ. 373, 149-171.

Fehrenbacher, J.B., 1973. Loess stratigraphy, distribution and time of deposition in Illinois. Soil Sci. 115, 176-182.

Foster, H.L., Laird, J., Keith, T.E.C., Cushing, G.W., Menzie, D.W., 1983. Preliminary geologic map of the Circle Quadrangle, Alaska. U.S. Geological Survey Open-File Report 83-170-A, scale, 1:250,000.

Frazee, C.J., Fehrenbacher, J.B., Krumbein, W.C., 1970. Loess distribution from a source. Soil Sci. Soc. Am. Proc. 34, 296-301.

Frechen, M., Kehl, M., Rolf, C., Sarvati, R., Skowronek, A., 2009. Loess chronology of the Caspian Lowland in northern Iran. Quatern. Int. 198, 220-233.

Frye, J.C., Glass, H.D., Willman, H.B., 1962. Stratigraphy and mineralogy of the Wisconsinan loesses of Illinois. Illinois State Geol. Surv. Circ. 334, 1-55.

Frye, J.C., Glass, H.D., Willman, H.B., 1968. Mineral zonation of Woodfordian loesses of Illinois. Illinois State Geol. Surv. Circ. 427, 1-44.

Frye, J.C., Glass, H.D., Kempton, J.P., Willman, H.B., 1969. Glacial tills of northwestern Illinois. Illinois State Geol. Surv. Circ. 437, 1-45.

Gallet, S., Jahn, B., Torii, M., 1996. Geochemical characterization of the Luochuan loesspaleosol sequence, China, and paleoclimatic implications. Chem. Geol. 133, 67-88.

Gallet, S., Jahn, B., Van Vliet-Lanoe, B., Dia, A., Rossello, E.A., 1998. Loess geochemistry and its implications for particle origin and composition of the upper continental crust. Earth Planet. Sci. Lett. 156, 157-172.

Garrels, R.M., Mackenzie, F.T., 1971. Evolution of Sedimentary Rocks. W.W. Norton \& Company, Inc., New York, pp. 397.

Graham, I.J., Ditchburn, R.G., Whitehead, N.E., 2001. Be isotope analysis of a 0-500 ka loess-paleosol sequence from Rangitatau East, New Zealand. Quatern. Int. 76 (77), 29-42.

Grimley, D.A., 2000. Glacial and nonglacial sediment contributions to Wisconsin Episode loess in the central United States. Geol. Soc. Am. Bull. 112, 1475-1495.

Grimley, D.A., Follmer, L.R., McKay, E.D., 1998. Magnetic susceptibility and mineral zonations controlled by provenance in loess along the Illinois and central Mississippi River valleys. Quatern. Res. 49, 24-36.

Grimley, D.A., Follmer, L.R., Hughes, R.E., Solheid, P.A., 2003. Modern, Sangamon and Yarmouth soil development in loess of unglaciated southwestern Illinois. Quatern. Sci. Rev. 22, 225-244.

Hall, R.D., Anderson, A.K., 2000. Comparative soil development of Quaternary paleosols of the central United States. Palaeogeogr. Palaeoclimatol. Palaeoecol. 158, 109-145.

Hallberg, G.R., Kemmis, T.J., 1986. Stratigraphy and correlation of the glacial deposits of the Des Moines and James lobes and adjacent areas in North Dakota, South Dakota, Minnesota, and Iowa. Quatern. Sci. Rev. 5, 65-68.

Hallberg, G.R., Lineback, J.A., Mickelson, D.M., Knox, J.C., Goebel, J.E., Hobbs, H.C., Whitfield, J.W., Ward, R.A., Boellstorf, J.D., Swinehart, J.B., Dreeszen, V.H., 1991 Quaternary geologic map of the Des Moines $4 \times 6$ quadrangle, United States. U.S. Geological Survey Miscellaneous Investigations Series Map I-1420 (NK-15), scale 1: 1, 000,000 .

Hallet, B., Hunter, L., Bogen, J., 1996. Rates of erosion and sediment evacuation by glaciers: a review of field data and their implications. Global Planet. Change 12 213-235.

Hamilton, T.D., 1982. A late Pleistocene glacial chronology for the southern Brooks Range: stratigraphic record and regional significance. Geol. Soc. Am. Bull. 93, 700-716.

Heberer, B., Anzenbacher, T., Neubauer, F., Genser, J., Dong, Y., Dunkl, I., 2014. Polyphase exhumation in the western Qinling Mountains, China: rapid early cretaceous cooling along a lithospheric-scale tear fault and pulsed Cenozoic uplift. Tectonophysics $617,31-43$.

Hopkins, D.M., 1963. Geology of the Imuruk Lake area, Seward Peninsula, Alaska. U.S. Geological Survey Bulletin 1141-C.

Hu, F., Yang, X., 2016. Geochemical and geomorphological evidence for the provenance of aeolian deposits in the Badain Jaran Desert, northwestern China. Quatern. Sci. Rev. 131, 179-192.

Hu, J., Wang, H., Wang, M., 2017. Provenance and tectonic setting of siliciclastic rocks associated with the Neoproterozoic Dahongliutan BIF: implications for the Precambrian crustal evolution of the Western Kunlun orogenic belt, NW China. J. Asian Earth Sci. 147, 95-115.

Jackson, M.G., Oskarsson, N., Trønnes, R.G., McManus, J.F., Oppo, D.W., Grönvold, K., Hart, S.R., Sachs, J.P., 2005. Holocene loess deposition in Iceland: evidence for millennial-scale atmosphere-ocean coupling in the North Atlantic. Geology 33, 509-512.

Jahn, B.-M., 2004. The Central Asian Orogenic Belt and growth of the continental crust in the Phanerozoic. In: Malpas, J., Fletcher, C.J.N., Ali, J.R., Aitchison, J.C. (Eds.), Aspects of the Tectonic Evolution of China, vol. 226. Geological Society of London Special Publications, pp. 73-100.

Jahn, B., Gallet, S., Han, J., 2001. Geochemistry of the Xining, Xifeng and Jixian sections, Loess Plateau of China: eolian dust provenance and paleosol evolution during the last 140 ka. Chem. Geol. 178, 71-94.

Jakobsson, S.P., Jónasson, K., Sigurdsson, I.A., 2008. The three igneous rock series of Iceland. Jökull 58, 117-138.

Jenny, H., 1941. Factors of Soil Formation. McGraw-Hill, New York, pp. 281.
Jeong, G.Y., Hillier, S., Kemp, R.A., 2008. Quantitative bulk and single-particle mineralogy of a thick Chinese loess-paleosol section: implications for loess provenance and weathering. Quatern. Sci. Rev. 27, 1271-1287.

King, J.E., Saunders, J.J., 1986. Geochelone in Illinois and the Illinoian-Sangamonian vegetation of the type region. Quatern. Res. 25, 89-99.

Kleiss, H.J., 1973. Loess distribution along the Illinois soil-development sequence. Soil Sci. 115, 194-198.

Kukla, G., Heller, F., Liu, X.M., Xu, T.C., Liu, T.S., An, Z.S., 1988. Pleistocene climates in China dated by magnetic susceptibility. Geology 16, 811-814.

Lewis, G.C., Fosberg, M.A., 1982. Distribution and character of loess and loess soils in southeastern Idaho. Idaho Bureau Min. Geol. Bull. 26, 705-716.

Li, J.J., 1991. The environmental effects of the uplift of the Qinghai- Xizang Plateau. Quatern. Sci. Rev. 10, 479-483.

Li, Y., Song, Y., Chen, X., LI, J., Mamadjanov, Y., Aminov, J., 2016. Geochemical composition of Tajikistan loess and its provenance implications. Palaeogeogr. Palaeoclimatol. Palaeoecol. 446, 186-194.

Liu, C.-Q., Masuda, A., Okada, A., Yabuki, S., Zhang, J., Fan, Z.-L., 1993. A geochemical study of loess and desert sand in northern China: implications for continental crust weathering and composition. Chem. Geol. 106, 359-374.

Liu, C.-Q., Masuda, A., Okada, A., Yabuki, S., Fan, Z.-L., 1994. Isotope geochemistry of Quaternary deposits from the arid lands in northern China. Earth Planet. Sci. Lett. 127, 25-38.

Liu, T.S., 1988. Loess in China, second ed. Springer, Berlin, pp. 224.

Liu, T.S., Ding, Z.L., 1998. Chinese loess and the paleomonsoon. Annu. Rev. Earth Planet. Sci. 26, 111-145.

Maat, P.B., Johnson, W.C., 1996. Thermoluminescence and new ${ }^{14} \mathrm{C}$ age estimates for late Quaternary loesses in southwestern Nebraska. Geomorphology 17, 115-128.

Maman, S., Blumberg, D.G., Tsoar, H., Mamedov, B., Porat, N., 2011. The Central Asian ergs: a study by remote sensing and geographic information systems. Aeol. Res. 3, 353-366.

Markewich, H.W., Wysocki, D.A., Pavich, M.J., Rutledge, E.M., 2011. Age, genesis, and paleoclimatic interpretation of the Sangamon/Loveland complex in the Lower Mississippi Valley, USA. Geol. Soc. Am. Bull. 123, 21-39.

Martinson, D.G., Pisias, N.G., Hays, J.D., Imbrie, J., Moore Jr., T.C., Shackleton, N.J., 1987. Age dating and the orbital theory of the Ice Ages: development of a highresolution 0 to 300,000-year chronostratigraphy. Quatern. Res. 27, 1-29.

Mason, B., Moore, C.B., 1982. Principles of Geochemistry. Wiley, New York, pp. 344.

Mason, J.A., 2001. Transport direction of Peoria Loess in Nebraska and implications for loess sources on the central Great Plains. Quatern. Res. 56, 79-86.

Mason, J.A., Joeckel, R.M., Bettis III, E.A., 2007. Middle to Late Pleistocene loess record in eastern Nebraska, USA, and implications for the unique nature of Oxygen Isotope Stage 2. Quatern. Sci. Rev. 26, 773-792.

Matsu'ura, T., Miyagi, I., Furusawa, A., 2011. Late Quaternary cryptotephra detection and correlation in loess in northeastern Japan using cummingtonite geochemistry. Quatern. Res. 75, 624-635.

McLennan, S.M., 1989. Rare earth elements in sedimentary rocks: influence of provenance and sedimentary processes. Rev. Mineral. 21, 169-200.

McLennan, S.M., 2001. Relationships between the trace element composition of sedimentary rocks and upper continental crust. Geochem. Geophys. Geosyst. 2, 2 2000GC000109.

Mickelson, D.M., Clayton, L., Fullerton, D.S., Borns Jr., H.W., 1983. The late Wisconsin glacial record of the Laurentide ice sheet in the United States. In: Wright Jr.H.E., Porter, S.C. (Eds.), Late-Quaternary Environments of the United States. University of Minnesota Press, Minneapolis, pp. 3-37.

Muhs, D.R., 2007. Loess deposits, origins and properties. In: Elias, S.A. (Ed.), Encyclopedia of Quaternary Sciences. Elsevier, Amsterdam, pp. 1405-1418.

Muhs, D.R., 2013a. Loess and its geomorphic, stratigraphic, and paleoclimatic significance in the Quaternary. In: Shroder, John F., (Editor-in-chief), Lancaster, N., Sherman, D.J., Baas, A.C.W. (Volume Editors). Treatise on Geomorphology, vol 11. Academic Press, Aeolian Geomorphology, San Diego, pp. 149-183.

Muhs, D.R., 2013b. Geologic records of dust in the Quaternary. Aeol. Res. 9, 3-48.

Muhs, D.R., Bettis III, E.A., 2000. Geochemical variations in Peoria Loess of western Iowa indicate paleowinds of midcontinental North America during last glaciation. Quatern. Res. 53, 49-61.

Muhs, D.R., Bettis III, E.A., 2003. Quaternary loess-paleosol sequences as examples of climate-driven sedimentary extremes. Geol. Soc. Am. Spec. Pap. 370, 53-74.

Muhs, D.R., Budahn, J.R., 2006. Geochemical evidence for the origin of late Quaternary loess in central Alaska. Can. J. Earth Sci. 43, 323-337.

Muhs, D.R., Aleinikoff, J.N., Stafford Jr., T.W., Kihl, R., Been, J., Mahan, S.A., Cowherd, S., 1999. Late Quaternary loess in northeastern Colorado: Part I-Age and paleoclimatic significance. Geol. Soc. Am. Bull. 111, 1861-1875.

Muhs, D.R., Bettis III, E.A., Been, J., McGeehin, J., 2001. Impact of climate and parent material on chemical weathering in loess-derived soils of the Mississippi River Valley. Soil Sci. Soc. Am. J. 65, 1761-1777.

Muhs, D.R., Ager, T.A., Bettis III, E.A., McGeehin, J., Been, J.M., Begét, J.E., Pavich, M.J., Stafford Jr., T.W., Pinney, D., 2003. Stratigraphy and paleoclimatic significance of late Quaternary loess-paleosol sequences of the last interglacial-glacial cycle in central Alaska. Quatern. Sci. Rev. 22, 1947-1986.

Muhs, D.R., McGeehin, J.P., Beann, J., Fisher, E., 2004. Holocene loess deposition and soil formation as competing processes, Matanuska Valley, southern Alaska. Quatern. Res. 61, 265-276.

Muhs, D.R., Budahn, J., Reheis, M., Beann, J., Skipp, G., Fisher, E., 2007a. Airborne dust transport to the eastern Pacific Ocean off southern California: evidence from San Clemente Island. J. Geophys. Res. 112, D13203. http://dx.doi.org/10.1029/ 2006JD007577.

Muhs, D.R., Budahn, J., Prospero, J.M., Carey, S.N., 2007b. Geochemical evidence for 
African dust inputs to soils of western Atlantic islands: Barbados, the Bahamas and Florida. J. Geophys. Res. 112, F02009. http://dx.doi.org/10.1029/2005JF000445.

Muhs, D.R., Bettis III, E.A., Aleinikoff, J., McGeehin, J.P., Beann, J., Skipp, G., Marshall, B.D., Roberts, H.M., Johnson, W.C., Benton, R., 2008a. Origin and paleoclimatic significance of late Quaternary loess in Nebraska: evidence from stratigraphy, chronology, sedimentology, and geochemistry. Geol. Soc. Am. Bull. 120, 1378-1407.

Muhs, D.R., Budahn, J., Johnson, D.L., Reheis, M., Beann, J., Skipp, G., Fisher, E., Jones, J.A., 2008b. Geochemical evidence for airborne dust additions to soils in Channel Islands National Park, California. Geol. Soc. Am. Bull. 120, 106-126.

Muhs, D.R., Ager, T.A., Skipp, G., Beann, J., Budahn, J.R., McGeehin, J.P., 2008c. Paleoclimatic significance of chemical weathering in loess-derived paleosols of subarctic central Alaska. Arct. Antarct. Alp. Res. 40, 396-411.

Muhs, D.R., Bettis III, E.A., Roberts, H.M., Harlan, S., Paces, J.B., Reynolds, R., 2013a. Chronology and provenance of last-glacial (Peoria) loess in western Iowa and paleoclimatic implications. Quatern. Res. 80, 468-481.

Muhs, D.R., Budahn, J.R., McGeehin, J.P., Bettis III, E.A., Skipp, G., Paces, J.B., Wheeler, E.A., 2013b. Loess origin, transport, and deposition over the past 10,000 years, Wrangell-St. Elias National Park, Alaska: Aeol. Res. 11, 85-99.

Muhs, D.R., Budahn, J.R., Skipp, G.L., McGeehin, J.P., 2016. Geochemical evidence for seasonal controls on the transportation of Holocene loess, Matanuska Valley, southern Alaska, USA. Aeol. Res. 21, 61-73.

Onishi, H., Sandell, E.B., 1955. Geochemistry of arsenic. Geochim. Cosmochim. Acta 7 $1-33$.

Péwé, T.L., 1975. Quaternary geology of Alaska. U.S. Geological Survey Professional Paper 835, 1-145.

Péwé, T.L., Journaux, A., 1983. Origin and character of loesslike silt in unglaciated southcentral Yakutia, Siberia, U.S.S.R. U.S. Geological Survey Professional Paper 1262, $46 \mathrm{pp}$.

Péwé, T.L., Liu, T.S., Slatt, R.M., Li, B.Y., 1995. Origin and character of loesslike silt in the southern Qinghai-Xizang (Tibet) Plateau, China. U.S. Geological Survey Professional Paper 1549, pp. 1-55.

Plafker, G., Berg, H.C., 1994. Overview of the geology and tectonic evolution of Alaska. In: Plafker, George, Berg, H.C. (Eds.), The geology of Alaska: Boulder, Colo., The Geological Society of America, The geology of North America, vol. G-1, pp. 989-1021 (Chapter 33).

Porter, S.C., 2001. Chinese loess record of monsoon climate during the last glacial-interglacial cycle. Earth Sci. Rev. 54, 115-128.

Porter, S.C., An, Z., 1995. Correlation between climate events in the North Atlantic and China during the last glaciation. Nature 375, 305-308.

Porter, S.C., Hallet, B., Wu, X., An, Z., 2001. Dependence of near-surface magnetic susceptibility on dust accumulation rate and precipitation on the Chinese Loess Plateau. Quatern. Res. 55, 271-283.

Pye, K., Johnson, R., 1988. Stratigraphy, geochemistry, and thermoluminescence ages of Lower Mississippi Valley loess. Earth Surf. Proc. Land. 13, 103-124.

Reed Jr., J.C., Wheeler, J.O., Tucholke, B.E., compilers, 2005. Geologic Map of North America. Decade of North American Geology Continental Scale Map 001, Boulder, Colorado, Geological Society of America, scale, 1: 5,000,000.

Reheis, M.C., 2003. Dust deposition in Nevada, California, and Utah, 1984-2002. U.S Geological Survey Open- File Report 03-138, version 1.0. < http://pubs.usgs.gov/ of/2003/ofr-03-138/>

Reheis, M.C., Budahn, J.R., Lamothe, P.J., 2002. Geochemical evidence for diversity of dust sources in the southwestern United States. Geochim. Cosmochim. Acta 66, 1569-1587.

Roberts, H.M., Muhs, D.R., Wintle, A.G., Duller, G.A.T., Bettis III, E.A., 2003. Unprecedented last glacial mass accumulation rates determined by luminescence dating of loess from western Nebraska. Quatern. Res. 59, 411-419.

Rolfe, T.C., Shaw, J., Derbyshire, E., Jingtai, W., 1989. A detailed geomagnetic record from Chinese loess. Phys. Earth Planet. Inter. 56, 151-164.

Rozycki, S.Z., 1991. Loess and Loess-Like Deposits. Ossolineum Press, Polish Academy of Sciences, Warsaw, pp. 187.

Ruhe, R.V., 1969. Quaternary Landscapes in Iowa. Iowa State University Press, Ames, Iowa, pp. 255.

Ruhe, R.V., 1974. Sangamon paleosols and Quaternary environments in Midwestern United States. In: Mahaney, W.C. (Ed.), Quaternary Environments: Proceedings of a Symposium, York University Geographical Monographs, vol. 5, pp. 153-167.

Ruhe, R.V., 1983. Depositional environment of late Wisconsin loess in the midcontinental United States. In: Wright Jr.H.E., Porter, S.C. (Eds.), Late-Quaternary Environments of the United States. University of Minnesota Press, Minneapolis, pp. 130-137.

Ruhe, R.V., Hall, R.D., Canepa, A.P., 1974. Sangamon paleosols of southwestern Indiana, U.S.A. Geoderma 12, 191-200.

Runge, E.C.A., Walker, T.W., Howarth, D.T., 1974. A study of late Pleistocene loess deposits, South Canterbury, New Zealand: Part I. Forms and amounts of phosphorous compared with other techniques for identifying paleosols. Quatern. Res. 4, 76-84.

Sainsbury, C.L., 1972. Geologic Map of the Teller Quadrangle, Western Seward Peninsula, Alaska. U.S. Geological Survey Miscellaneous Geologic Investigations Map I-685, scale 1:250,000.

Schaetzl, R.J., Thompson, M.L., 2015. Soils: Genesis and Geomorphology, second ed. Cambridge University Press, Cambridge, pp. 795.

Shi, Y., 1980. Glaciers in China. Shanghai Scientific and Technical Publishers, Shanghai 100 pp.

Simonson, R.W., 1954. Identification and interpretation of buried soils. Am. J. Sci. 252, 705-732.

Smalley, I.J., 1995. Making the material: the formation of silt-sized primary mineral particles for loess deposits. Quatern. Sci. Rev. 14, 645-651.

Smalley, I.J., Vita-Finzi, C., 1968. The formation of fine particles in sandy deserts and the nature of 'desert' loess. J. Sediment. Petrol, 38, 766-774.
Smalley, I.J., Krinsley, D.H., 1978. Loess deposits associated with deserts. Catena 5, $53-66$

Smith, G.D., 1942. Illinois loess: variations in its properties and distribution, a pedologic interpretation. Univ. Illinois Agric. Exp. Station Bull. 490, 139-184.

Snowden, J.O., Priddy, R.R., 1968. Geology of Mississippi loess. Mississippi Geol. Surv. Bull. 111, 13-203.

Sun, J., 2002a. Provenance of loess material and formation of loess deposits on the Chinese Loess Plateau. Earth Planet. Sci. Lett. 203, 845-859.

Sun, J., 2002b. Source regions and formation of the loess sediments on the high mountain regions of northwestern China. Quatern. Res. 58, 341-351.

Sun, J., Liu, T., 2000. Stratigraphic evidence for the uplift of the Tibetan Plateau between $\sim 1.1$ and $\sim 0.9$ myr ago. Quatern. Res. 54, 309-320.

Sun, J., Muhs, D.R., 2007. Dune fields: mid-latitudes. In: Elias, S. (Ed.), The Encyclopedia of Quaternary Sciences. Elsevier, Amsterdam, pp. 607-626.

Sun, J., Zhang, M., Liu, T., 2001. Spatial and temporal characteristics of dust storms in China and its surrounding regions, 1960-1999: relations to source area and climate. J. Geophys. Res. 106, 10325-10333.

Sun, J., Li, S.-H., Muhs, D.R., Li, B., 2007. Loess sedimentation in Tibet: provenance, processes, and link with Quaternary glaciations. Quatern. Sci. Rev. 26, 2265-2280.

Swinehart, J.B., Dreeszen, V.H., Richmond, G.M., Tipton, M.J., Bretz, R., Steece, F.V., Hallberg, G.R., Goebel, J.E., 1994a. Quaternary Geologic Map of the Platte River $4 \times 6$ Quadrangle. United States. U.S. Geological Survey Miscellaneous Investigations Series Map I-1420 (NK-14). Scale 1:1,000,000.

Tao, H., Sun, S., Wang, Q., Yang, X., Jiang, L., 2014. Petrography and geochemistry of lower carboniferous greywacke and mudstones in Northeast Junggar, China: implications for provenance, source weathering, and tectonic setting. J. Asian Earth Sci. 87, 11-25.

Taylor, S.R., McLennan, S.M., 1985. The Continental Crust: its Composition and Evolution. Blackwell Scientific Publications, Oxford, pp. 312.

Taylor, S.R., McLennan, S.M., 1995. The geochemical evolution of the continental crust. Rev. Geophys. 33, 241-265.

Taylor, S.R., McLennan, S.M., 2009. Planetary Crusts: Their Composition, Origin and Evolution. Cambridge University Press, Cambridge, pp. 378.

Taylor, S.R., McLennan, S.M., McCulloch, M.T., 1983. Geochemistry of loess, continental crustal composition and crustal model ages. Geochim. Cosmochim. Acta 47, 1897-1905.

Thordarson, T., Larsen, G., 2007. Volcanism in Iceland in historical time: volcano types, eruption styles and eruptive history. J. Geodyn. 43, 118-152.

Thorp, J., 1945. Discussion of: "Glacial versus desert origin of loess". Am. J. Sci. 243, $246-247$.

Thorp, J., Johnson, W.M., Reed, E.C., 1951. Some post-Pliocene buried soils of central United States. J. Soil Sci. 2, 1-19.

Velichko, A.A., Bogucki, A.B., Morozova, T.D., Udartsev, V.P., Khalcheva, T.A., Tsatskin, A.I., 1984. Periglacial landscapes of the East European Plain. In: Velichko, A.A. Wright Jr.H.E., Barnosky, C.W. (Eds.), Late Quaternary Environments of the Soviet Union. University of Minnesota Press, Minneapolis, pp. 94-118.

Velichko, A.A., Morozova, T.D., Nechaev, V.P., Rutter, N.W., Dlusskii, K.G., Little, E.C., Catto, N.R., Semenov, V.V., Evans, M.E., 2006. Loess/paleosol/cryogenic formation and structure near the northern limit of loess deposition, East European Plain, Russia. Quatern. Int. 152 (153), 14-30.

Verosub, K.L., Fine, P., Singer, M.J., TenPas, J., 1993. Pedogenesis and paleoclimate: interpretation of the magnetic susceptibility record of Chinese loess-paleosol sequences. Geology 21, 1011-1014.

Wang, T., Tong, Y., Zhang, L., Li, S., Huang, H., Zhang, J., Guo, L., Yang, Q., Hong, D., Donskaya, T., Gladkochub, D., Tserendash, N., 2017. Phanerozoic granitoids in the central and eastern parts of Central Asia and their tectonic significance. J. Asian Earth Sci in press.

Wang, Z., 2004. Tectonic evolution of the western Kunlun orogenic belt, western China. J. Asian Earth Sci. 24, 153-161.

Watanuki, T., Murray, A.S., Tsukamoto, S., 2005. Quartz and polymineral luminescence dating of Japanese loess over the last 0.6 Ma: comparison with an independent chronology. Earth Planet. Sci. Lett. 240, 774-789.

Weber, F.R., Wheeler, K.L., Rinehart, C.D., Light, T.D., 1997. Generalized geologic map of the Livengood Quadrangle, Alaska. U.S. Geological Survey Open-File Report 97-484A, scale, 1:250,000.

Westgate, J.A., Stemper, B.A., Péwé, T.L., 1990. A 3 m.y. record of Pliocene-Pleistocene loess in interior Alaska. Geology 18, 858-861.

Williams, J.R., 1962. Geologic reconnaissance of the Yukon Flats district, Alaska. U.S. Geological Survey Bulletin 1111-H, pp. H289-H331.

Winkler, G.R., 2000. A geologic guide to Wrangell-St. Elias National Park and Preserve, Alaska: a tectonic collage of northbound terranes. U.S. Geological Survey Professional Paper 1616, 166 pp.

Wintle, A.G., Shackleton, N.J., Lautridou, J.P., 1984. Thermoluminescence dating of periods of loess deposition and soil formation in Normandy. Nature 310, 491-493.

Wright, J.S., 2001a. "Desert" loess versus "glacial" loess: quartz silt formation, source areas and sediment pathways in the formation of loess deposits. Geomorphology 36, 231-256.

Wright, J., 2001b. Making loess-sized quartz silt: data from laboratory simulations and implications for sediment transport pathways and the formation of 'desert' loess deposits associated with the Sahara. Quatern. Int. 76 (77), 7-19.

Xie, Y., Chi, Y., 2016. Geochemical investigation of dry- and wet-deposited dust during the same dust-storm event in Harbin, China: Constraint on provenance and implications for formation of aeolian loess. J. Asian Earth Sci. 120, 43-61.

Yang, S., Ding, F., Ding, Z., 2006. Pleistocene chemical weathering history of Asian arid and semi-arid regions recorded in loess deposits of China and Tajikistan. Geochim. Cosmochim. Acta 70, 1695-1709. 
Yang, Y., Zhu, B., White, P.D., 2007. Provenance of aeolian sediment in the Taklamakan Desert of western China inferred from REE and major-elemental data. Quatern. Int. $175,71-85$.

Yang, Y., Mason, J.A., Zhang, H., Lu, H., Ji, J., Chen, J., Liu, L., 2017. Provenance of loess in the central Great Plains, U.S.A., based on Nd-Sr isotopic composition, and paleoenvironmental implications. Quatern. Sci. Rev. 173, 114-123.

Zhang, K.-J., 2004. Secular geochemical variations of the Lower Cretaceous siliciclastic rocks from central Tibet (China) indicate a tectonic transition from continental collision to back-arc rifting. Earth Planet. Sci. Lett. 229, 73-89.
Zhang, H., Lu, H., Jiang, S.-Y., Vandenberghe, J., Wang, S., Cosgrove, R., 2012. Provenance of loess deposits in the Eastern Qinling Mountains (central China) and their implications for the paleoenvironment. Quaternary Sci. Rev. 43, 94-102.

Zhou, B., Dong, Y., Zhang, F., Yang, Z., Sun, S., He, D., 2016. Geochemistry and zircon U$\mathrm{Pb}$ geochronology of granitoids in the East Kunlun Orogenic Belt, northern Tibetan Plateau: origin and tectonic implications. J. Asian Earth Sci. 130, 265-281.

Zhou, S.Z., Jijun, L., Zhang, S.Q., Zhao, J.D., Cui, J.X., 2004. Quaternary glaciations in China. In: Ehlers, J., Gibbard, P.L. (Eds.), Quaternary Glaciations-Extent and Chronology, Part III. Elsevier, Amsterdam, pp. 105-113. 